SOIL, WATER, AND STREAMBED QUALITY AT A DEMOLISHED ASPHALT PLANT, FORT BRAGG, NORTH CAROLINA, 1992-94

By Ted R. Campbell

U.S. GEOLOGICAL SURVEY

Water-Resources Investigation Report 95-4215

Prepared in cooperation with the

U.S. DEPARTMENT OF ARMY

Columbia, South Carolina 1996 


\section{U.S. DEPARTMENT OF THE INTERIOR \\ BRUCE BABBITT, Secretary}

U.S. GEOLOGICAL SURVEY

Gordon P. Eaton, Director

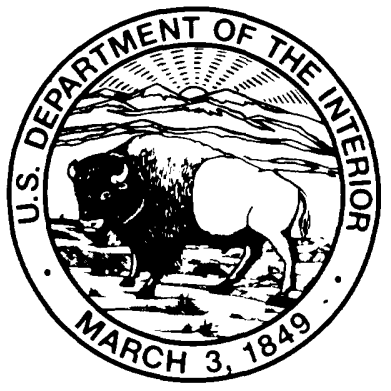

For additional information write to:

District Chief

U.S. Geological Survey

Stephenson Center- Suite 129

720 Gracern Road

Columbia, SC 29210-7651
Copies of this report can be purchased from:

U.S. Geological Survey

Earth Science Information Center

Open-File Reports Section

Box 25286, Mail Stop 517

Denver Federal Center

Denver, CO 80225 


\section{CONTENTS}

Page

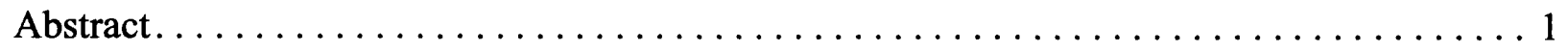

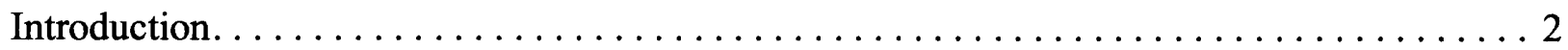

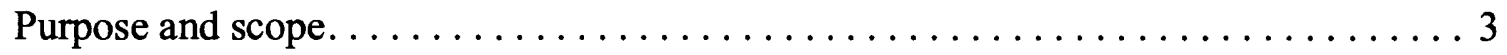

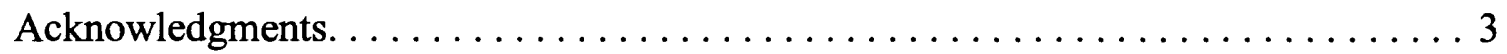

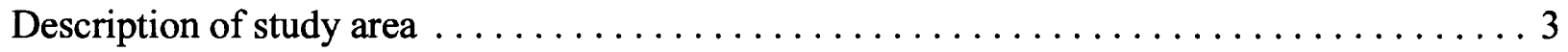

Regional hydrogeology ............................. 5

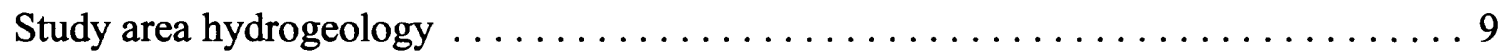

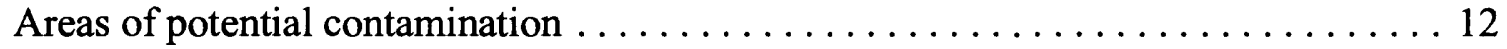

Physical and chemical characteristics of source materials $\ldots \ldots \ldots \ldots \ldots \ldots 16$

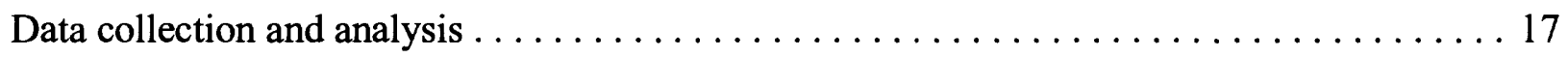

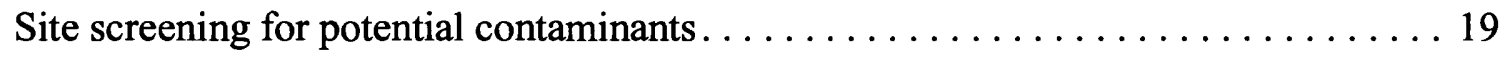

Surface-geophysical surveys. ........................ 20

Sampling for volatile organic compounds in soil gas............. 23

Monitoring-well installation and development. ................... 23

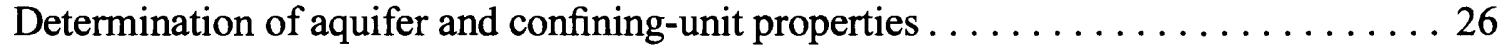

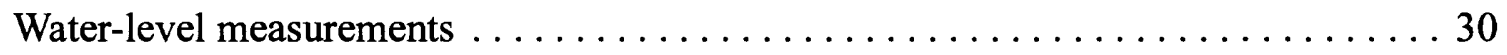

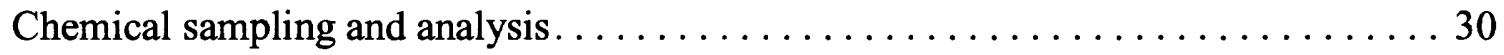

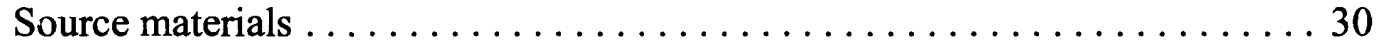

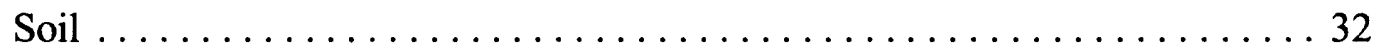

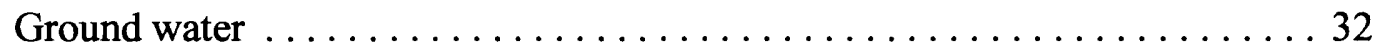

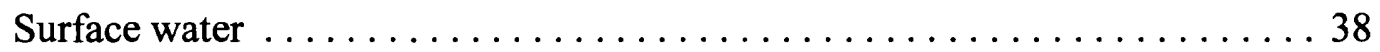

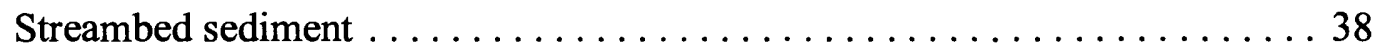

Quality of source materials, soil, water, and streambed sediment $\ldots \ldots \ldots \ldots \ldots \ldots \ldots$

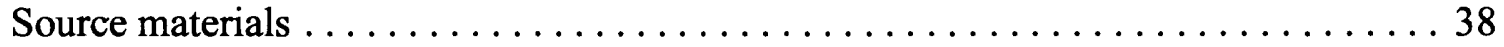

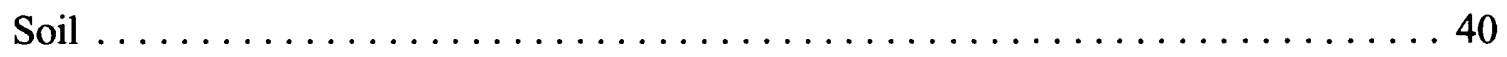

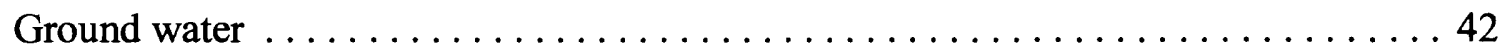

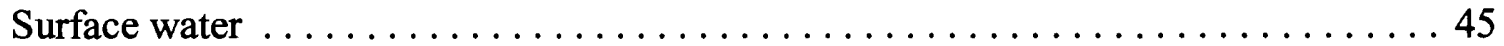

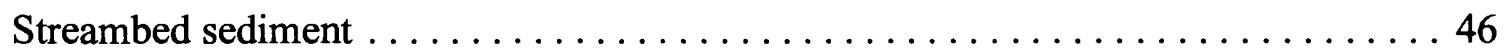

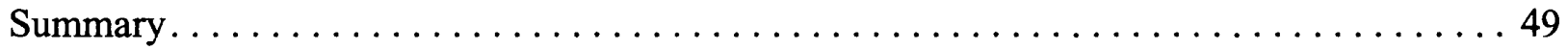

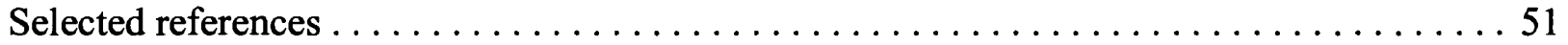

Appendix 1. Gamma logs from site BS1 and selected wells installed during this investigation. . . . . . . . . . . . . . . 76

Appendix 2. Descriptive logs of cores from monitoring wells installed during this

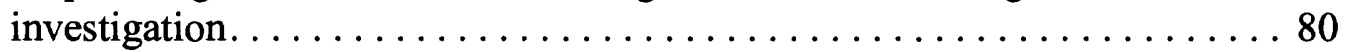

Appendix 3. Slug-test data collected on wells MW.DAP4D and MW.DAP3D,

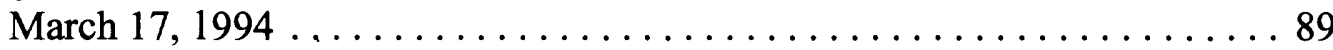


Figures 1-3. Maps showing:

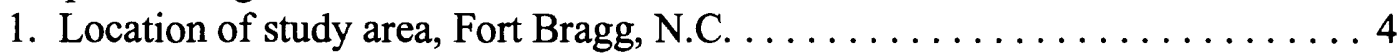

2. Potential source areas of Demolished Asphalt Plant activity, topography, and location of solid-waste management unit $63 \ldots \ldots \ldots 6$

3. Surface-water drainage patterns and flood-plain boundaries in the

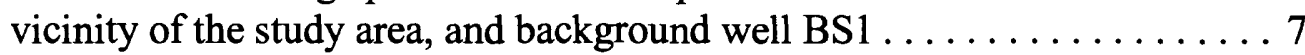

4. Chart showing regional geologic and hydrogeologic units $\ldots \ldots \ldots \ldots \ldots 8$

5-11. Maps showing:

5. Ground-water elevations in the study area, based on data collected April 20, 1994 . .

6. Topography, source material, monitoring-well locations, surface-water sample location of March 17, 1994, and streambed sample location of March 18, 1994, in Areas 1, 2, 3, and 4........ 13

7. Buildings in the study area during the 1940's to 1960's and solid-waste management unit 63, superimposed on 1994 Joint Special Operations Command area map ...

8. Quadrature and inphase results of EM-31 survey made in Areas 1 and 2 on February 9, 1993, and in Area 5, January 4, 1993 ........ 21

9. Ground-penetrating radar survey locations of December $12,1992 \ldots \ldots 22$

10. Site-safety screening soil-gas and soil-boring sample locations, December 15-17, $1992 \ldots \ldots \ldots \ldots \ldots \ldots \ldots \ldots \ldots \ldots \ldots \ldots . \ldots \ldots$

11. Soil-gas sample locations, February 23-24, 1993 and June 22, $1993 \ldots \ldots .25$

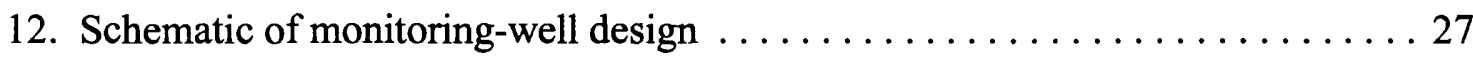

13-14. Maps showing:

13. Source-material sample locations, June $29-30,1993 \ldots \ldots \ldots \ldots \ldots . \ldots 31$

14. Near-surface soil sample locations, August 27 to

November $1,1993 \ldots \ldots \ldots \ldots \ldots \ldots \ldots \ldots \ldots \ldots \ldots \ldots . \ldots \ldots$

15. Schematic showing analytical soil-sample depths in monitoring-well boreholes drilled August 27 to November 1, 1993 . . . . . . . . . . . . . 36 


\section{TABLES}

Table 1. Organic compounds in commercial roofing tar and raw bitumen samples, and experimentally determined octanol-water partition coefficients, solubilities, and vapor pressures. . . . . . . . . . . . . 18

2. Construction details of monitoring wells, and water-level data

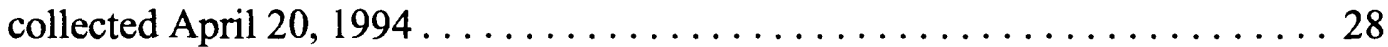

3. Methods used in the analysis of source material samples collected

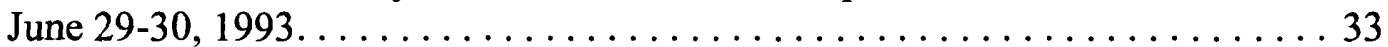

4. Analytical methods and detection limits for surface-soil samples and soil-boring samples collected between August 27 and November 1, 1993; water samples collected between February 25 and March 17, 1994; and streambed samples collected on March 18, $1994 \ldots \ldots \ldots \ldots \ldots \ldots 55$

5. Summary of analytical results of source-material samples collected

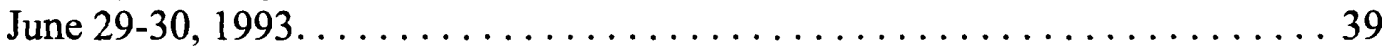

6. Site-safety screening results of soil samples collected December 15-17, 1992 ................................... 41

7. Summary of analytical results of surface-soil samples and soil-boring samples collected between August 27 and November 1, 1993 .......... 62

8. Summary of analytical results of water samples collected between

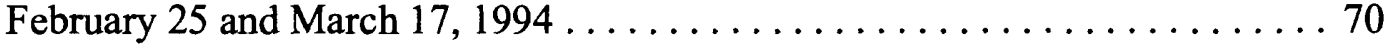

9. Aqueous solubilities, octanol-water partition coefficients, and sorption coefficients for selected organochlorine insecticides . .

10. Summary of analytical results of a streambed sample collected on March 18, 1994. 


\section{Length}

foot (ft)

foot per mile ( $\mathrm{ft} / \mathrm{mi})$

inch (in.)

inch per year (in/yr)

mile (mi)

acre

square mile $\left(\mathrm{mi}^{2}\right)$

gallon (gal)

cubic foot per second $\left(\mathrm{ft}^{3} / \mathrm{s}\right)$

million gallons per day (Mgal/d)

gallon per minute (gal $/ \mathrm{min})$

gallon per day (gal/d)

\author{
0.3048 \\ 0.1894 \\ 25.4 \\ 25.4 \\ 1.609
}

$\underline{\text { Area }}$

4,047

2.590

\section{Volume}

3.785

\section{Flow}

0.02832

0.04381

0.06309

0.003785 meter

meter per kilometer

millimeter

millimeter per year

kilometer

square meter

square kilomete-

\section{Hydraulic conductivity}

foot per day ( $\mathrm{ft} / \mathrm{d})$

foot per year $(\mathrm{ft} / \mathrm{yr})$
0.3048

0.3048 cubic meter per second cubic meter per second liter per second cubic meter per day 


\section{CONVERSION FACTORS, VERTICAL DATUM, ACRONYMS, AND ABBREVIATIONS--Continued}

Sea level: In this report "sea level" refers to the National Geodetic Vertical Datum of 1929 -- a geodetic datum derived from a general adjustment of the first-order level nets of the United States and Canada, formerly called Sea Level Datum of 1929.

Specific conductance of water is expressed in microsiemens per centimeter at $25^{\circ} \mathrm{C}(\mu \mathrm{S} / \mathrm{sm})$.

Water temperature is given in degrees Celsius $\left({ }^{\circ} \mathrm{C}\right)$, which can be converted to degrees Fahrenheit $\left({ }^{\circ} \mathrm{F}\right)$ by the following equation:

$$
{ }^{\circ} \mathrm{F}=1.8\left({ }^{\circ} \mathrm{C}\right)+32
$$

Additional abbreviations:

Chemical concentration in water is expressed in milligrams per liter $(\mathrm{mg} / \mathrm{L})$ or micrograms per liter $(\mu \mathrm{g} / \mathrm{L})$.

Chemical concentration in soil and streambed sediment is expressed in milligrams pe* kilogram $(\mathrm{mg} / \mathrm{kg})$ or micrograms per kilogram $(\mu \mathrm{g} / \mathrm{kg})$.

$\mu \mathrm{m}$ - micrometer

$\mathrm{mS} / \mathrm{m}$ - millisiemens per meter

$\mu \mathrm{L} / \mathrm{L}$ - microliter per liter

Other abbreviations and acronyms used in this report:
AFB Air Force Base
asl above sea level
ASTM American Society for Testing Materials
BHC benzene hexachloride
bls below land surface
BTEX benzene, toluene, ethylbenzene, and xylene
DAP demolished asphalt plant
DDD dichlorodiphenyldichloroethane
DDE dichlorodiphenylchloroethylene
DDT dichlorodiphenyltrichloroethane
DPWE Department of Public Works and Environment
GPR ground penetrating radar
JSOC Joint Special Operations Command
MCL maximum contaminant level 


\section{CONVERSION FACTORS, VERTICAL DATUM, ACRONYMS, AND ABBREVIATIONS--Continued}

Other abbreviations and acronyms used in this report--Continued:

$\begin{array}{ll}\text { PAH } & \text { polynuclear aromatic hydrocarbon } \\ \text { PCB } & \text { polychlorinated biphenyl } \\ \text { ppt } & \text { parts per thousand } \\ \text { PVC } & \text { polyvinyl chloride } \\ \text { RCRA } & \text { Resource, Conservation, and Recovery Act } \\ \text { RFI } & \text { RCRA Facility Investigation } \\ \text { SWMU } & \text { solid waste management unit } \\ \text { TCLP } & \text { toxicity characteristic leachate procedure } \\ \text { TDS } & \text { total dissolved solids } \\ \text { TKN } & \text { total kjeldahl nitrogen } \\ \text { TOC } & \text { total organic carbon } \\ \text { TPH } & \text { total petroleum hydrocarbons } \\ \text { USEPA } & \text { U.S. Environmental Protection Agency } \\ \text { USGS } & \text { U.S. Geological Survey } \\ \text { VOC } & \text { volatile organic compound }\end{array}$

Use of brand, firm, or trade names in this report is for identification purposes only and does not constitute endorsement by the U.S. Government. 


\title{
SOIL, WATER, AND STREAMBED QUALITY AT A DEMOLISHED ASPHALT PLANT AREA AT FORT BRAGG, NORTH CAROLINA, 1992-94
}

\author{
By Ted R. Campbell
}

\section{ABSTRACT}

A number of potentially hazardous chemicals were used at an asphalt plant on the Fort Bragg U.S. Army Reservation near Fayetteville, North Carolina. This plant was demolished in the late 1960's. Samples collected from soil, ground water, surface water, and streambed sediment were tested for the presence of contaminants.

The sediment immediately underlying the demolished asphalt plant site consists mainly of sands, silts, and clayey sands with interbedded clay occurring at various depths. About 12 in hes of rainfall per year infiltrate the unconfined surficial aquifer. The water table in this area is about 233 to 243 feet above sea level. Local ground water moves laterally, mainly towards the north-tonorthwest at a rate of about 35 feet per year, where it discharges to Tank Creek, Little River, or one of their tributaries. A series of confining clays separate the surficial aquifer from the underlying upper Cape Fear aquifer. These clays help retard vertical migration of constituents dissolved in ground water. The saprolite-bedrock aquifer lies below the upper Cape Fear aquifer.

In general, ground water in the seven monitoring wells screened in the upper and lower part of the surficial aquifer did not contain detectable concentrations of chemicals related to past asphalt-plant activities. A small number of chemicals that were assumed to be unrelated to the asphalt plant were present in some of the study area monitoring wells. Ground water in four wells contained concentrations of organochlorine pesticides. Of these pesticides, concentratiors of gamma-benzene hexachloride (lindane) (maximum of 0.76 micrograms per liter) exceeded the U.S. Environmental Protection Agency maximum contaminant level of 0.2 micrograms per liter in two wells. In addition, one well contained a trichloroethane concentration ( 7.7 micrograms per liter) that is assumed to be unrelated to demolished asphalt-plant operations, but exceeded the U.S. Environmental Protection Agency maximum contaminant level of 5.0 micrograms per liter. One well contained a fluoride concentration of 5.2 milligrams per liter that exceeded the U.S. Environmental Protection Agency maximum contaminant level of 4.0 milligrams per liter. Total and dissolved metals concentrations were generally typical of background levels. Some of the wells contained elevated levels of chloride (maximum of 749 milligrams per liter), specific conductance (maximum of 2,780 microsiemens per centimeter at 25 degrees Celsius), and dissolved solids (maximum of 1,520 milligrams per liter). 
Twelve of twenty-two soil samples that were collected at various depths at monitoring-well locations did not contain volatile organic compounds or polynuclear aromatic hydrocarbc $\eta s$. The remaining ten soil samples contained very low concentrations of polynuclear aromatic hydrocarbons and (or) analytical laboratory-related volatile organic compounds. The maximum concentrations were for fluoranthene and pyrene, at 780 and 750 micrograms per kilogram, respectively. In general, the polynuclear aromatic hydrocarbon concentrations were in sediment near the land surface. Streambed sediment from an unnamed, eastern tributary to Tank Creek in the eastern part of the site contained a small number of organochlorine pesticide compounds (a maximum of 1,400 milligrams per kilogram of 4,4'-DDD) and total petroleum hydrocarbons (113 milligrams per kilogram). Concentrations of metals and other inorganic constituents were generally typical of background concentrations. Surface water in this tributary did not contain elevated concentrations of anthropogenic chemicals.

\section{INTRODUCTION}

A number of potentially hazardous chemicals were used at an asphalt plant on the Ft. Bragg U.S. Army Reservation (Fort Bragg) near Fayetteville, N.C. during its operation betr'een the early 1940's and the late 1960's, when the plant was demolished. Possible materials disposed at this site include asphalt and tar-related organic chemicals such as polynuclear aromatic hydrocarbons (PAHs). The site may also contain other chemicals associated with asphalt production, handling, and cleaning, including diesel fuel, number-2 fuel oil, naphtha, and kerosene. Records of material usage were not kept; therefore, the current understanding of material usage is based largely on historical accounts and knowledge of standard c perating procedures. Hardened asphalt and (or) coal tar are visible at land surface at several locations in the study area. It is unknown whether these materials represent leftover, end-of-day roadbed and (or) roofing material, or unprocessed, more-concentrated chemicals. Potentially, these materials could affect the quality of local ground water. A small part of the site, on the Joint Special Operations Command (JSOC), is situated on top of fill material used during construction grading.

The U.S. Geological Survey (USGS), in cooperation with the U.S. Department of the Army (Army), investigated potential contamination in the area of the demolished asphalt plant (DAP). Samples collected from soil, ground water, surface water, and streambed sediment were tested for the presence of contaminants. This investigation was designed to supply military persornel with information pertinent to ongoing base development and to determine whether the site should be added to the list of solid-waste management units (SWMUs) under the Ft. Bragg F esource Conservation and Recovery Act (RCRA) permit. The investigation generally followed the technical requirements outlined in the RCRA Facility Investigation (RFI) workplan (S.J. Mackmull, Ft. Bragg, N.C., written commun., 1991), which was prepared for several SWMUs currently (1995) being studied on Ft. Bragg. The RFI workplan received approval from the Army and the U.S. Environmental Protection Agency (USEPA). Field work was initiated in D?cember 1992 and was completed in April 1994. 


\section{Purpose and Scope}

The purpose of this report is to describe the soil, ground-water, surface-water, and streambed-sediment quality in the area of the DAP at Ft. Bragg, N.C. This report also describes the hydrogeologic characteristics of the study area.

The results presented in this report are based on information obtained from soil-gas sampling; geophysical surveys; source-material sampling; monitoring-well installation; chemical analyses of soil, ground water, surface water, and streambed sediment; and historical data. Seven monitoring wells were installed and sampled for a suite of volatile organic compounds (VOCs), base/neutral and acid extractable (semivolatile) organic compounds, pesticides and polychlorinated biphenyls (PCBs), total and dissolved metals, and selected inorganic constituents. One additional monitoring well was used for water-level measurements. Six of the wells were screened near the surface of the water table in the surficial aquifer; two of the wells were screened just above a clay layer separating the surficial aquifer from the underlying upper Cape Fear aquifer. Determinations of local ground-water-flow characteristics and potential pathways of contaminant transport were based on water-level measurements, lithologic data, boreholegeophysical surveys, laboratory tests for soil permeability, and slug tests. Although several subsurface investigations have been made at and around Ft. Bragg and the adjacent Pope Air Force Base (Pope AFB), no information was found concerning previous investigations in the immediate study area. The investigation was limited to the area associated with the DAP.

\section{Acknowledgments}

Special thanks are extended to Steve Mackmull, Bill Kern, and Joe Stancar, Ft. Bragg Department of Public Works and Environment, and to Eldridge Barefoot, JSOC. These individuals assisted in the initiation and logistics of field work and reporting. Special appreciation is also extended to Fred Waller, Asphalt Institute; Mr. Garner, U.S. Department of Army; and Arthur Whittington, U.S. Department of Army retiree, who provided information on current and historic operation of asphalt plants and past study-area operations.

\section{DESCRIPTION OF STUDY AREA}

The study area is located on Ft. Bragg, 10 miles (mi) northwest of the city of Fayetteville, N.C., in the northwestern part of Cumberland County (fig. 1). Ft. Bragg is located in the Sand Hills of the North Carolina Coastal Plain physiographic province. The area is characterized by deep, mainly poorly consolidated sediment, gently rolling topographic relief, and land-surface elevations ranging from about 170 to 280 feet ( $\mathrm{ft}$ ) above sea level (asl).

The region surrounding Ft. Bragg is characterized by rural and forested land, military facilities, suburban communities, and commercial and industrial development. Ft. Bragg shares part of its northern boundary with Pope AFB. 


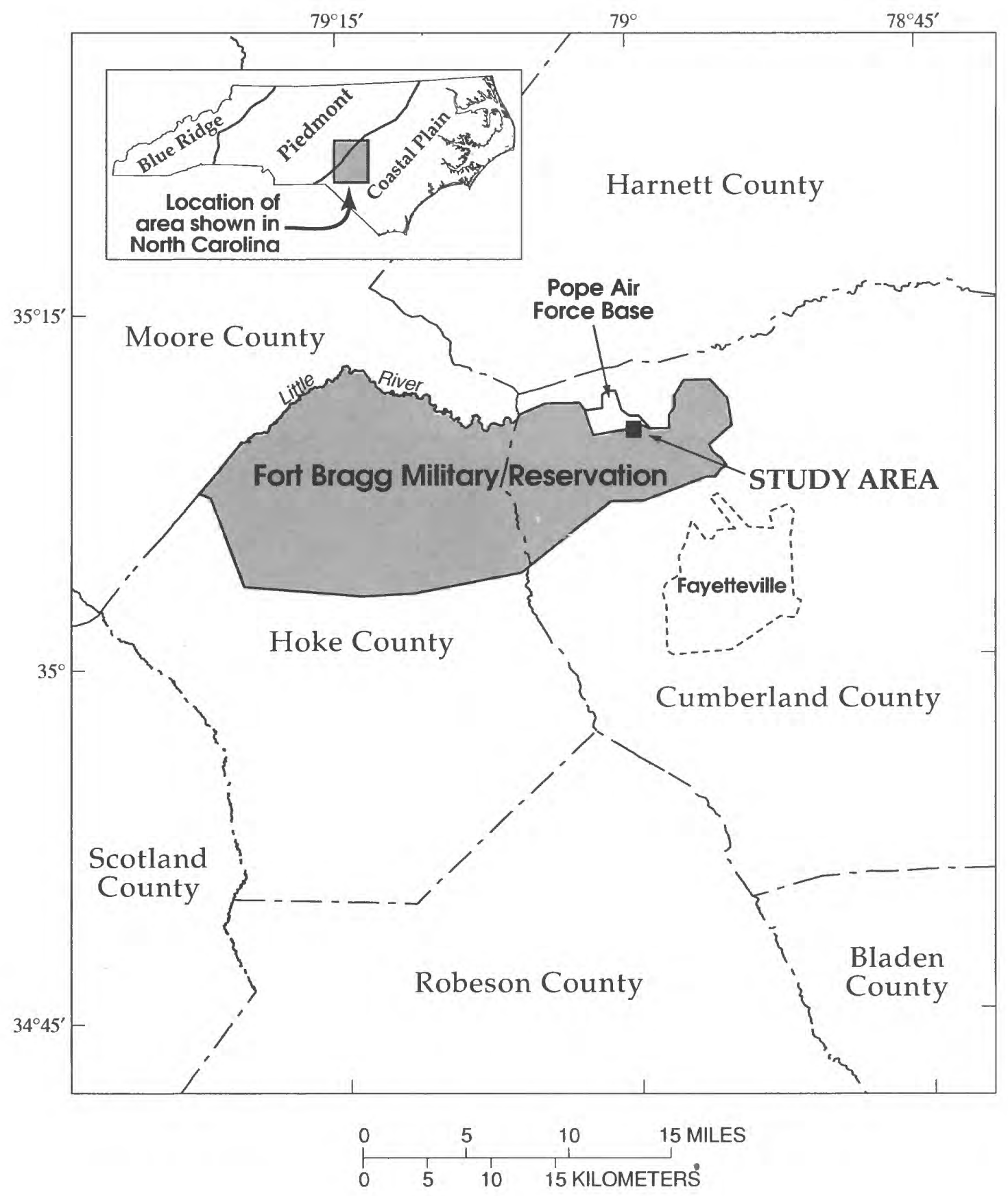

Figure 1. Location of study area, Fort Bragg, North Carolina. 
The DAP study area is located between Reilly Street and Hurst Drive in the northeastern part of the Ft. Bragg installation (fig. 2). The site covers approximately 5 acres and is situated in an area between the Pope AFB security gate on Reilly Street, the JSOC, Hurst Drive, and SWMU 63 (fig. 2). Due to the nature of past asphalt production, storage, handling, and transport operations at the DAP, specific site boundaries do not exist. The study area location and extent are defined by areas of past activity and are not delineated by distinct boundaries. The eastern part of the DAP lies within the boundary of Pope AFB, in an undeveloped, wooded area. The central part of the DAP is undeveloped and lightly wooded. The northwestern part of the DAP is located on JSOC, in a grassed area containing a small number of office buildings. The southern part of the site, on the Ft. Bragg public-works compound, is primarily an open area of packed sediment overlain by a thin layer of loose sand. This area is used for the outdoor storage of steel tanks and various industrial supplies. Three railroad spurs, once used for coal staging, are located in this area.

Surface-water drainage from the study area is toward Tank Creek by way of two unnamed tributaries, north and east of the DAP, whose headwaters are immediately downgradient of the site (fig. 3). All of the tributaries in the area converge to Tank Creek, which flows northeast and discharges to the Little River.

The annual mean rainfall for the study area from 1931-60 was 46.44 inches (in.) (National Oceanic and Atmospheric Administration, 1974). The monthly average rainfall for this period varied from 2.25 in. in October to $6.0 \mathrm{in}$. in July.

\section{Regional Hydrogeology}

The study area is located in the Coastal Plain physiographic province, a region characterized by an eastward-thickening sequence of sand, silt, clay, and limestone (Giese and others, 1991). This sequence thickens and gently slopes to the southeast at about 6 feet per mile $(\mathrm{ft} / \mathrm{mi})$. The source of water for the aquifer system is recharge from precipitation. Recharge to the surficial aquifer is about 12 inches per year (in/yr) (Giese and others, 1991). Of this, about 11 in. moves laterally to streams, and about $1 \mathrm{in}$. or less moves downward through confining clays to the underlying aquifers.

The geologic units underlying the region include pre-Cretaceous metavolcanic, metasedimentary, and igneous rocks (Conley, 1962) (fig. 4). These sediments are unconformably overlain by late Cretaceous-age sediments of the Cape Fear Formation and the Middendorf Formation. Above these, Tertiary units, including the Pinehurst Formation and other unnamed Eocene-age deposits occur in some locations.

The regional ground-water flow system has been characterized by Winner and Coble (1989) as being comprised of three aquifers, each separated by a laterally continuous confining unit (fig. 4). From shallow to deep, the ground-water-flow system includes: the surficial aquifer, consisting of Tertiary sediment; the Black Creek aquifer, consisting of upper Cretaceous sediment; and the upper Cape Fear aquifer, consisting of upper Cretaceous sediment. PreCretaceous basement rock forms the lower boundary of the flow system. 


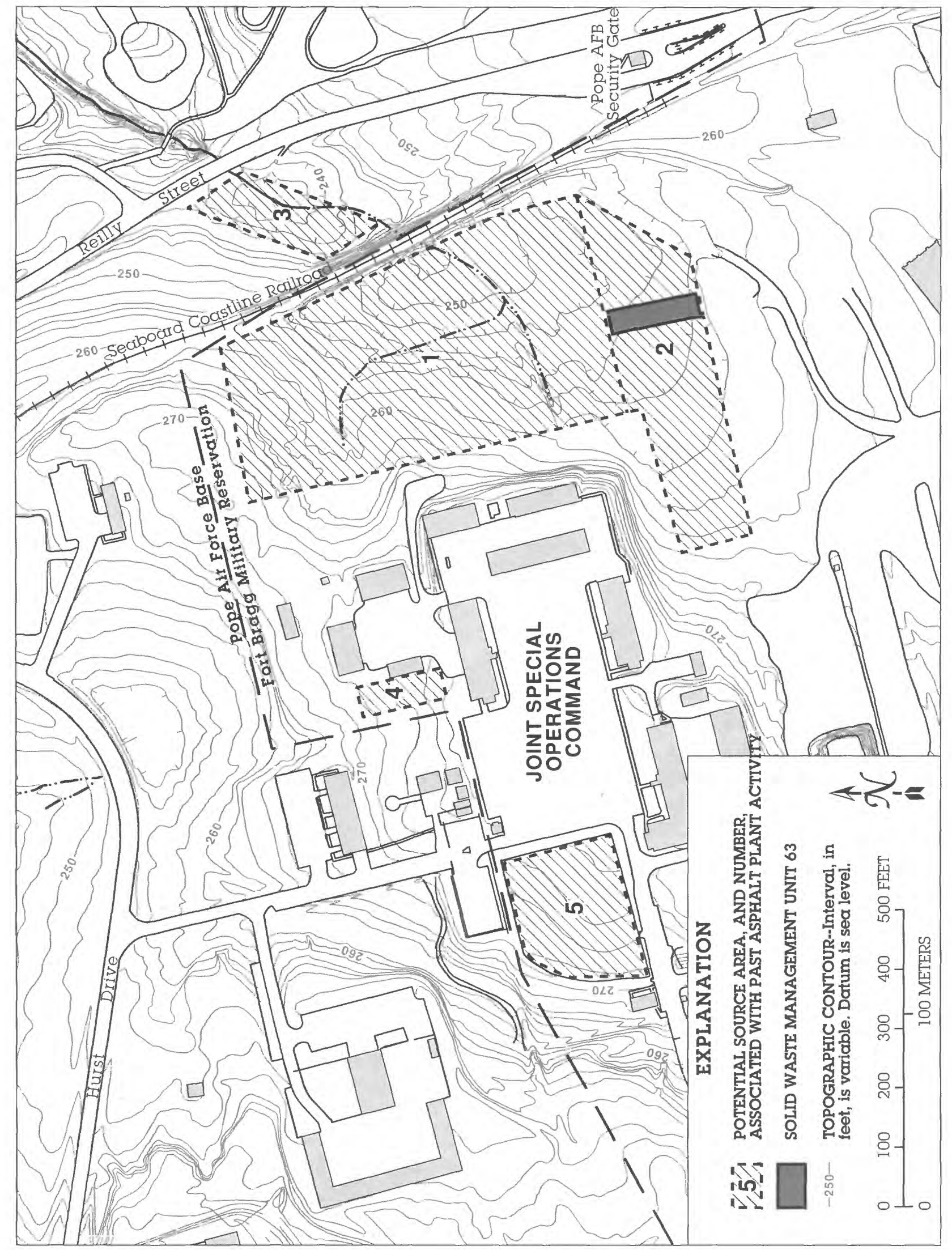

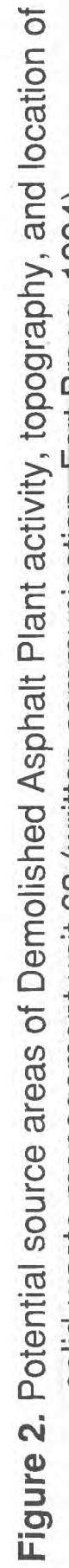




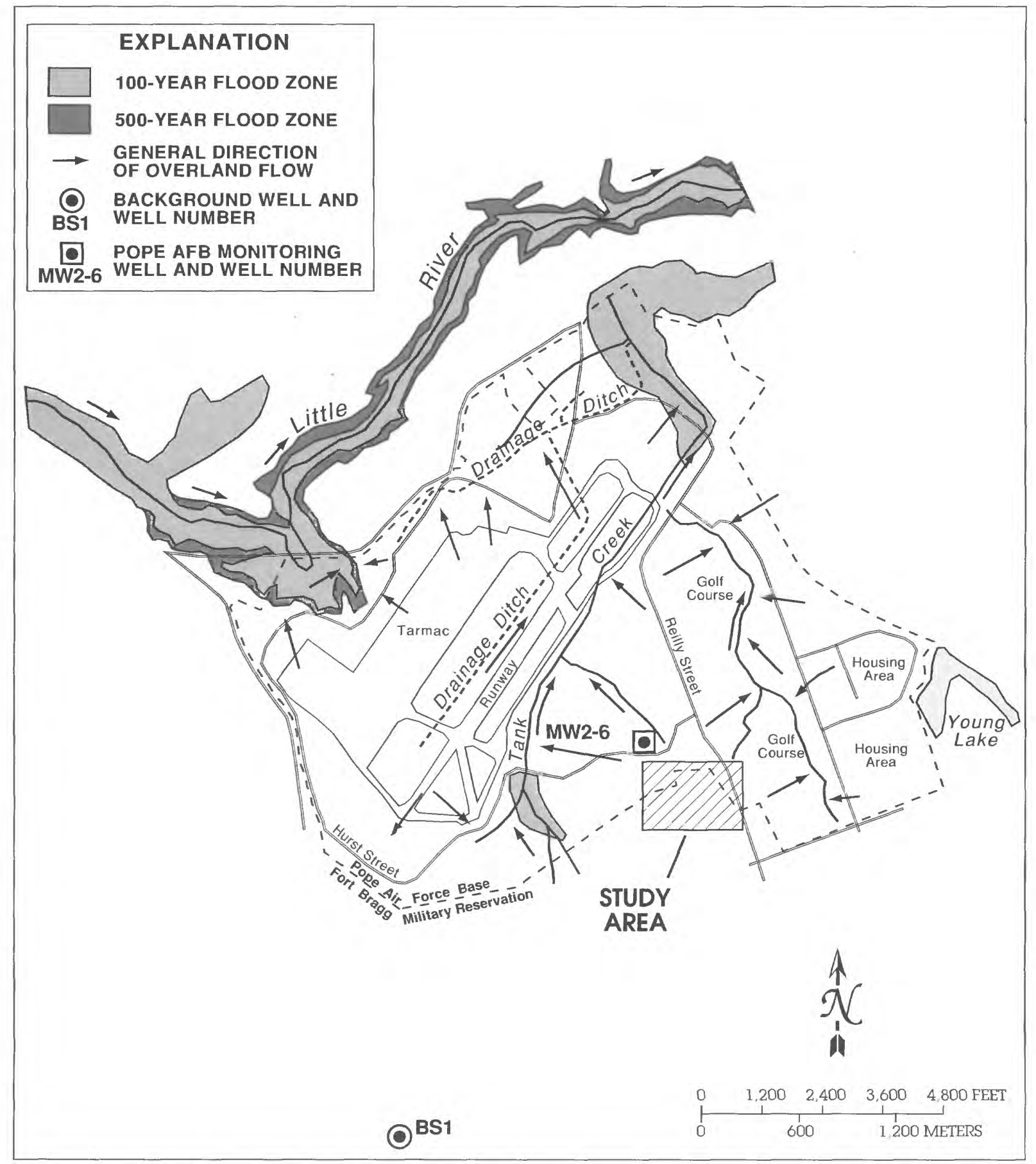

Figure 3. Surface-water drainage patterns and flood-plain boundaries in the vicinity of the study area, and background well BS1 (modified from Remedial Investigation Report, Phase 2, 1993). 


\begin{tabular}{|c|c|c|c|c|c|}
\hline & \multicolumn{2}{|c|}{ Conley (1962) } & $\begin{array}{c}\text { North } \\
\text { Carolina } \\
\text { Office of } \\
\text { Water } \\
\text { Resources } \\
(1980)\end{array}$ & $\begin{array}{l}\text { Winner and } \\
\text { Coble (1989) }\end{array}$ & $\begin{array}{l}\text { This } \\
\text { Report }\end{array}$ \\
\hline SYSTEM & \multicolumn{2}{|c|}{ GEOLOGIC UNITS } & \multicolumn{3}{|c|}{ HYDROGEOLOGIC UNITS } \\
\hline \multirow{2}{*}{ Tertiary } & \multirow{2}{*}{$\begin{array}{l}\text { Pinehurst } \\
\text { Formation }\end{array}$} & \multirow{2}{*}{$\begin{array}{c}\text { Unnamed } \\
\text { Eocene-age } \\
\text { Deposits }\end{array}$} & \multirow{3}{*}{$\begin{array}{l}\text { Sandhills } \\
\text { Aquifer }\end{array}$} & $\begin{array}{l}\text { Surficial } \\
\text { Aquifer }\end{array}$ & $\begin{array}{c}\text { Tertiary } \\
\text { Units Not } \\
\text { Present at }\end{array}$ \\
\hline & & & & \begin{tabular}{|c|}
$\begin{array}{c}\text { Black Creek } \\
\text { Confining } \\
\text { Unit }\end{array}$ \\
\end{tabular} & $\begin{array}{c}\text { Demolished } \\
\text { Asphalt } \\
\text { Plant Site } \\
\end{array}$ \\
\hline \multirow{3}{*}{$\begin{array}{l}\text { Late } \\
\text { Cretaceous }\end{array}$} & \multicolumn{2}{|c|}{ Middendorf Formation } & & $\begin{array}{c}\text { Black Creek } \\
\text { Aquifer }\end{array}$ & $\begin{array}{l}\text { Surficial } \\
\text { Aquifer }\end{array}$ \\
\hline & \multirow{2}{*}{\multicolumn{2}{|c|}{ Cape Fear Formation }} & \multirow{2}{*}{$\begin{array}{l}\text { Cape Fear } \\
\text { Aquitard }\end{array}$} & \begin{tabular}{|c|} 
Upper Cape \\
$\begin{array}{c}\text { Fear Confin- } \\
\text { ing Unit }\end{array}$ \\
\end{tabular} & $\begin{array}{c}\text { Upper Cape } \\
\text { Fear Confin- } \\
\text { ing Unit }\end{array}$ \\
\hline & & & & $\begin{array}{l}\text { Upper } \\
\text { Cape Fear } \\
\text { Aquifer }\end{array}$ & $\begin{array}{l}\text { Upper } \\
\text { Cape Fear } \\
\text { Aquifer }\end{array}$ \\
\hline \multirow{2}{*}{$\begin{array}{c}\text { Pre- } \\
\text { Cretaceous }\end{array}$} & \multirow{2}{*}{\multicolumn{2}{|c|}{$\begin{array}{l}\text { Metavolcanic, } \\
\text { Metasedimentary, } \\
\text { and Igneous Rocks }\end{array}$}} & \multirow[t]{2}{*}{ Basement } & \multirow{2}{*}{$\begin{array}{c}\text { Basement } \\
\text { Rock }\end{array}$} & $\begin{array}{l}\text { Saprolite } \\
\text { Bedrock } \\
\text { Aquifer }\end{array}$ \\
\hline & & & & & $\begin{array}{l}\text { Basement } \\
\text { Rock }\end{array}$ \\
\hline
\end{tabular}

Figure 4. Regional geologic and hydrogeologic units. 
To date, no evidence has been found for the presence of Tertiary rock units in the Ft. Bragg area (B.A. Lisle, U.S. Geological Survey, written commun., 1993). Furthermore, it was determined that the Middendorf aquifer, and not the Black Creek aquifer, is present in the Ft. Bragg area (Remedial Investigation Report, 1993; and B.A. Lisle, U.S. Geological Survey, written commun., 1993). Therefore, for the purpose of this study, the hydrogeologic framework in the study area was characterized to include three aquifers (fig. 4): the Middendorf aquifer referred to in this report as the surficial aquifer, the upper Cape Fear aquifer, and the saprolitebedrock aquifer. Basement rock forms the lower boundary of the flow system.

Use of ground water is limited in the Ft. Bragg area. Twenty-six water-supply wells are located on Ft. Bragg, with depths ranging from 62 to $600 \mathrm{ft}$ below land surface (bls) (average is $176 \mathrm{ft} \mathrm{bls}$ ) and yields ranging from 5 to 170 gallons per minute (gal $/ \mathrm{min})$ (B.A. Lisle, U.S. Geological Survey, written commun., 1993). These wells are generally used for irrigation and, in remote areas of Ft. Bragg, for potable purposes. Most of the potable water used at Ft. Bragg is from the Little River. There are no drinking-water wells located within a one-mile radius of the DAP study area (Remedial Investigation Report, 1993).

\section{Study Area Hydrogeology}

The hydrogeology and geology of the DAP site is described in terms of the lithologic and geophysical data collected in the study area monitoring wells. These data were compared to lithologic data collected during a SWMU investigation (B.A. Lisle, U.S. Geological Survey, written commun., 1993) at a background monitoring-well cluster site, BS1, located about $6,000 \mathrm{ft}$ southwest of the DAP (fig. 3). Site BS1 is located at an elevation of $235 \mathrm{ft}$ asl; the deepest well was drilled to $160 \mathrm{ft}$ bls. At this location, sands and clays of the Middendorf Formation were encountered to a depth of about $30 \mathrm{ft}$ bls. Below this, the Cape Fear Formation, consisting of dense clays with interbedded silty sands, was encountered to a depth of about $105 \mathrm{ft}$ bls. A saprolitic zone of red and green clays was encountered from 105 to $130 \mathrm{ft}$ bls. Chlorite schist bedrock was reached at $130 \mathrm{ft}$ bls. Natural gamma-ray logs for wells drilled at BS1 are shown in appendix 1 .

Lithology at the DAP was compared to data from a monitoring-well boring from MW 2-6 (255 ft asl) on Pope AFB (fig. 3) located about $700 \mathrm{ft}$ north of the study area. In this well boring, sands and clays of the Middendorf Formation were encountered to a depth of $220 \mathrm{ft}$ asl. Clays of the Cape Fear Formation were below this depth.

The study area is comprised of three hydrogeologic units: the surficial aquifer, the upper Cape Fear aquifer, and the saprolite-bedrock aquifer. The surficial aquifer overlies the upper Cape Fear confining unit. This aquifer is comprised of sediments of the Middendorf Formation and includes mainly fine to medium sand, interbedded with silty clay, coarser channel sand, and thinly laminated sand and clay (Giese and others, 1991). Discontinuous clay lenses result in occasional perched water tables. In an area just west of Ft. Bragg, the surficial aquifer contains perched water tables and deeper ground-water flow zones (R.W. Coble, U.S. Geological Survey, written commun., 1993). Perched water tables in the Ft. Bragg area generally occur within $20 \mathrm{ft}$ of land surface, are usually no more than a few feet thick, and are unconfined (B.A. Lisle, U.S. Geological Survey, written commun., 1993). 
The upper Cape Fear aquifer unconformably overlies the saprolite-bedrock aquifer. The upper Cape Fear aquifer is comprised mainly of alternating beds of sand and clay, with individual beds ranging in thickness from about $3 \mathrm{ft}$ to $15 \mathrm{ft}$. The average thickness of the aquifer is about $100 \mathrm{ft}$. The uppermost part of the upper Cape Fear aquifer is exposed north and south of Ft. Bragg where rivers have scoured through overlying material (B.A. Lisle, U.S. Geological Survey, written commun., 1993). The upper Cape Fear confining unit overlies the upper Cape Fear aquifer (Winner and Coble, 1989). The confining unit in the Ft. Bragg area is between 50 and 80 $\mathrm{ft}$ thick, and consists of nearly continuous clay, silty clay, and sandy clay beds. Because of the high percentage of clay in the upper Cape Fear aquifer, it is often difficult to determine exactly where the upper Cape Fear aquifer ends and the overlying upper Cape Fear confining unit begins. The transitional clay layers in this area are, at least locally, hydrogeologic confining units.

The saprolite-bedrock aquifer is comprised of igneous and metamorphic rocks of preCretaceous age. The uppermost part of these basement rocks forms a saprolitic zone of heavily fractured, chemically weathered material (Winner and Coble, 1989). Basement rocks are not exposed in the Ft. Bragg area. In general, Carolina Slate Belt rocks are located at a depth of about $100 \mathrm{ft}$ asl in the study region.

Wells at the DAP were drilled to depths ranging from 25 to $70 \mathrm{ft}$ bls in the surficial aquifer. Study area lithology generally consisted of fine to coarse sand, silty sand, and clayey sand of the Middendorf Formation intermixed with occasional thin clay and silt stringers. Below these strata were clays and sandy clays characteristic of the Cape Fear Formation.

Several clay cores were analyzed for vertical hydraulic conductivity by falling-head permeameter tests. Results of these tests generally indicate that the clays encountered during drilling have hydraulic conductivity values as low as $3 \times 10^{-5} \mathrm{ft} / \mathrm{d}$. Lithologic profiles and wellscreen intervals of the DAP wells are presented in appendix 2.

The DAP is located in a recharge area of the surficial aquifer, with the exception of the easternmost part of the site. Ground-water elevations at the site vary from about 12 to $40 \mathrm{ft}$ bls, but are near land surface in the area of the eastern, unnamed tributary to Tank Creek (fig. 5). This tributary is hereafter referred to as the eastern tributary. Beginning about $100 \mathrm{ft}$ upstream of the culvert underlying Reilly Street, the eastern tributary contains ground-water discharge throughout much of the year. Ground water generally flows from the southeast to the northwest toward the unnamed Tank Creek tributary located north of Hurst Drive. This follows the regional trend of ground-water flow toward Tank Creek and Little River to the north. Tank Creek and Little River act as lines of ground-water discharge for the regional drainage basin.

The primary direction of ground-water flow is to the north-to-northwest, although the land surface in the study area tends to dip to the southeast (from an elevation of $273 \mathrm{ft}$ asl in the area of MW.DAP4S and MW.DAP4D, to $254 \mathrm{ft}$ asl in the area of MW.DAP5S) (fig. 5). Discharge to the eastern tributary originates primarily from the south. The fact that ground water flows primarily south-to-north demonstrates the influence that Tank Creek and Little River have on ground-water flow patterns, even in the vicinity of the DAP.

Perched water tables may occur in the uppermost part of the surficial aquifer in the study area. A 1- to 2-ft thick, laterally discontinuous clay lens was encountered in wells MW.DAP3S and MW.DAP3D at about $13 \mathrm{ft}$ bls, but perched water-table conditions were not present. This 


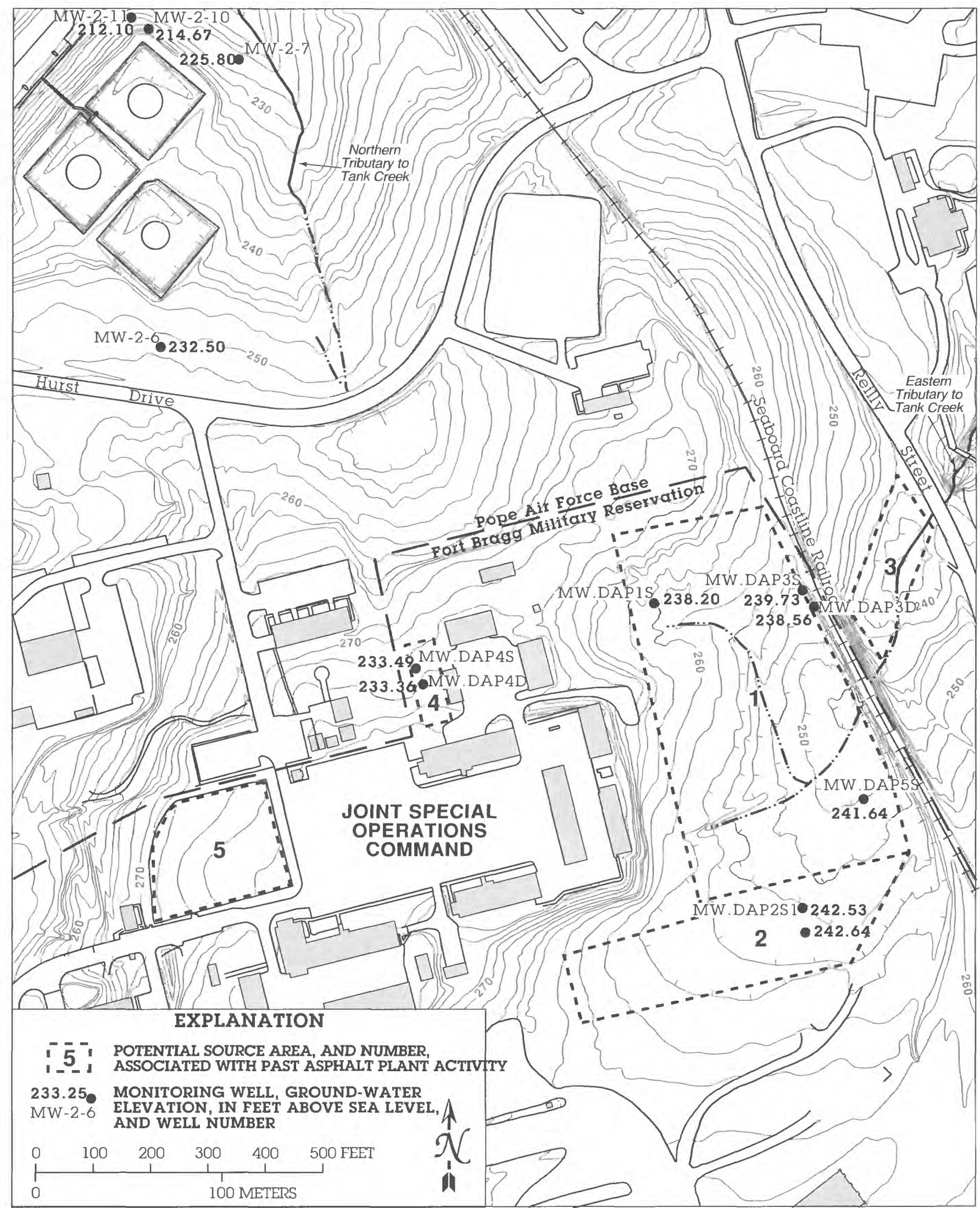

Figure 5. Ground-water elevations in the study area based on data collected April 20, 1994. 
was the only clay lens identified in the unsaturated zone during the investigation. In addition to clay lenses, which impede vertical ground-water flow, heterogeneous lithology underlying the DAP (variable grain size and clay content with depth) results in varying horizontal and vertical hydraulic conductivity depending on location and depth.

\section{Areas of Potential Contamination}

Records were not kept for materials or quantities handled, processed, spilled, or disposed of on site. It is unknown whether the source material in the study area is an asphalt or coal-tar product. However, the study area is comprised of four areas associated with past asphalt-plant operations (fig. 2):

Area 1: asphalt-plant operations area;

Area 2: emulsified asphalt-disposal trench;

Area 3: bitumen-covered tributary; and

Area 4: asphalt- or tar-disposal area.

Initially, it was believed that a fifth area (fig. 2) may have contained a number of buried drums related to asphalt-plant operations. The area was the location of a half-buried 55-gallon drum of roofing tar. On the basis of surface geophysical surveys, there was no evidence of additional buried drums in the immediate vicinity. It was concluded that the area and drum apparently were not associated with the DAP. A JSOC building was constructed in 1993 at this location following the geophysical survey. No other geophysical anomalies were noted in this area.

Area 1, the site of the asphalt-plant operations area, is located between the JSOC eastern fenceline and the Seaboard Railway tracks along the Ft. Bragg/Pope AFB boundary (fig. 6). The plant was operated from the early 1940's to the late 1960's and was dismantled and removed after military paving operations were transferred to private contractors. The plant consisted of two portable batch facilities, an asphalt-storage area, and a facility cleaning area (A. Whittington, U.S. Department of Army retiree, oral commun., February 19, 1993). The facility reportedly covered approximately 2 acres. The plant received asphalt cement (the main component in asphalt mixtures) from tanker trucks and rail cars, and, occasionally, in 55-gallon drums. Asphalt was heated and processed on-site at a rate of about 100 tons of material per hour.

A number of petroleum hydrocarbons were used at the plant during processing and cleaning (A. Whittington, U.S. Department of Army retiree, oral commun., February 19, 1993). For example, diesel and number-2 fuel oil were used to clean plant equipment and asphalt truck beds, and number-2 fuel oil was used to fire the plant oven. In addition, petroleum compounds such as kerosene and naphtha were used periodically as softening agents. These compounds are referred to as cutbacks in the asphalt industry, and were used in a ratio of one part cutback to two parts asphalt cement. 


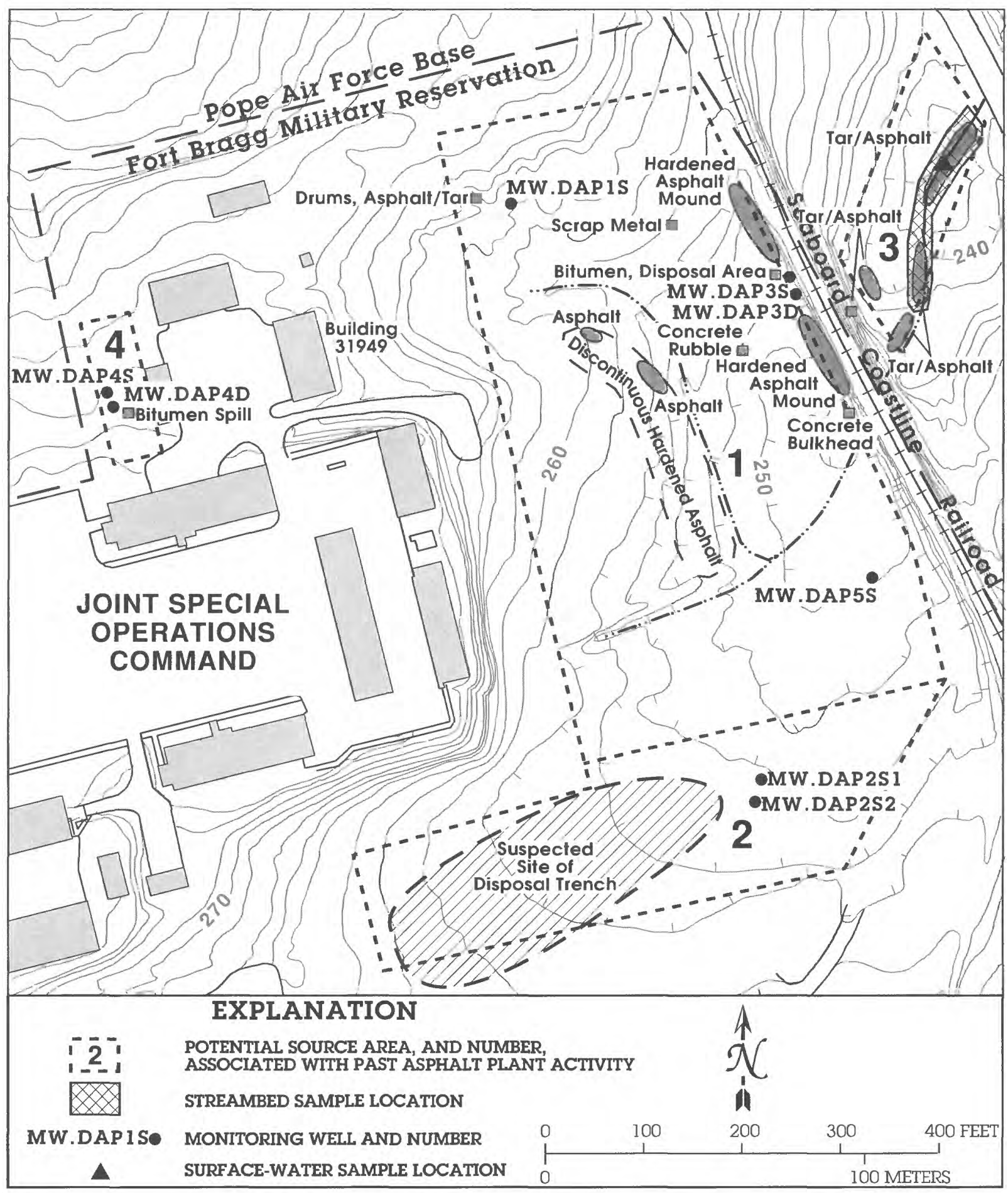

Figure 6. Topography, source material, monitoring-well locations, surface-water sample location of March 17, 1994, and streambed sample location of March 18,1994, in areas 1, 2, 3, and 4. 
Area 1 contains a long, discontinuous mound of hardened and weathered asphalt; remains of a bitumen spill; a cluster of six rusted, half-buried drums; a $5-\mathrm{ft}$ by 5 - $\mathrm{ft}$ concrete bulkhead apparently associated with the plant facility; and scattered pieces of exposed metal, concrete, and asphalt rubble (fig. 6). The discontinuous asphalt mound is roughly $1-\mathrm{ft}$ high, $10-\mathrm{ft}$ wide, and 150-ft long, and appears to be immobile. Spilled bitumen is located in the northeastern part of Area 1 and covers an area of about 100 square feet $\left(\mathrm{ft}^{2}\right)$. The spill probably resulted from end-ofday disposal of leftover materials, end-of-day cleaning, or disposal of bitumen that did not meet roadbed construction specifications. It is unknown whether petroleum cutbacks were used in this material. The rusted drums, believed to contain hardened emulsified asphalt and (or) coal tar, lie in a topographically upgradient part of Area 1, about $75 \mathrm{ft}$ east of the JSOC eastern fenceline and about $200 \mathrm{ft}$ south of the JSOC northeastern property corner. The concrete bulkhead and rubble are apparently the remains of the demolished asphalt facility. Quantities of the source materials in Area 1 are unknown.

The location of potential source materials in Area 1 is consistent with the historic location of buildings shown in the base planning reports (Ft. Bragg, N.C., written commun., 1948) (fig. 7). Area 1 was also the location of four tanks of unspecified size, a set of hoppers, a pump house, a boiler house, and an open shed (fig. 7). A storage building, small office, and an open lumber shed also were located in this area.

Area 1 has sandy soils, is wooded, and slopes gently to the southeast (fig. 6). The landsurface elevation ranges from about $250 \mathrm{ft}$ to $265 \mathrm{ft}$ asl. A clay-bottom gully has formed topographically downgradient from the rusted drums and extends to a storm drain inlet at the railway tracks in the southeastern corner of Area 1. The gully is dry, except during heavy rainfall. In addition, a concrete culvert in the southwestern corner of Area 1 discharges storm runoff to a drainage swale. During heavy runoff, the swale receives runoff from the eastern part of the JSOC, the central and southern part of Area 1, and from Area 2. Although the swale is normally dry, a number of wetland flora occur along parts of its streambed. Runoff flows through the swale and to the concrete storm-drain inlet at the base of the railway tracks. From here, it flows to the east through the culvert to the eastern tributary of Tank Creek located on Pope AFB (fig. 6). The tributary flows perennially starting at a point about $100 \mathrm{ft}$ topographically downgradient from the railway track culvert.

Area 2 is the location of a disposal trench, which reportedly received liquid emulsified asphalt in the early to mid-1970's (fig. 6) (A. Whittington, U.S. Department of Army, oral commun., February 19, 1993). The trench is located in the fenced storage area about $400 \mathrm{ft}$ north of SWMU 63 and $100 \mathrm{ft}$ south of the JSOC southern fenceline. Reportedly, the trench was about 5- to 7 - $\mathrm{ft}$ deep, 10- to 15 - $\mathrm{ft}$ wide, and about 150 - to 200-ft long. Approximately 5,000 to 7,000 gallons of excess liquid asphalt were poured into the trench from 55-gallon drums. Afterwards, the trench was immediately covered, and the empty drums were disposed in a Ft. Bragg solidwaste landfill. The asphalt reportedly did not contain added petroleum cutbacks.

According to the base planning reports (Ft. Bragg, N.C., written commun., 1948), Area 2 was also the location of a materials storage yard, two wooden warehouses, and a small wooden storage shed (fig. 7). The materials stored in these facilities are unknown, but pesticides may have been stored here (Mr. Garner, U.S. Department of Army, oral commun., May 26, 1993). 


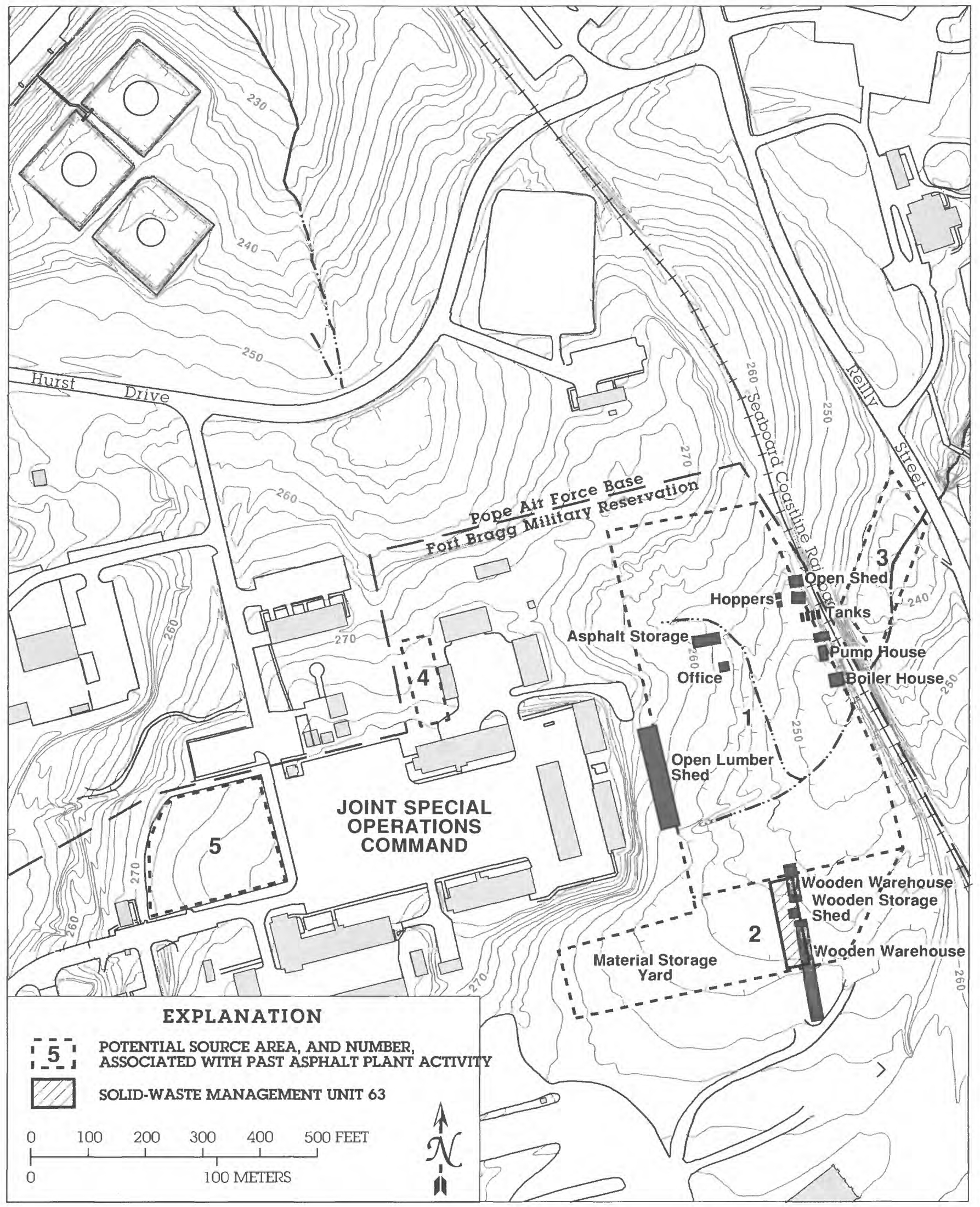

Figure 7. Buildings in the study area during the 1940's to 1960's and solid-waste management unit 63, superimposed on 1994 Joint Special Operations Command area map. 
Area 2 is topographically downgradient from light development in the central and eastern part of the JSOC (fig. 6). The area is sandy, open, and relatively flat. Land-surface elevation in this area is about $255 \mathrm{ft}$ asl and slopes slightly to the northeast in the direction of the drainage swale in the southern part of Area 1. Empty storage tanks and various industrial parts are stored in the open in this area.

Area 3 is the location of the bitumen-covered eastern tributary with headwaters located in the eastern part of the study site (fig. 6). The eastern tributary, located on Pope AFB, receives storm runoff from the railway culvert in the southeastern corner of Area 1. The tributary channel varies in width from about 2 to $5 \mathrm{ft}$, and varies in depth from about 2 to $4 \mathrm{ft}$. Depth of water during low-flow conditions varied from $0.0 \mathrm{ft}$ to about $1.5 \mathrm{ft}$ during the project period, depending on location. The bitumen material covers the tributary nonuniformly from the culvert inlet on Ft. Bragg to about $200 \mathrm{ft}$ downgradient, just west of Reilly Street. The 30-in.-diameter culvert contains several flow lines of tar or asphalt residue on the inside of the pipe. These residual "markers" are evidence of several tar or asphalt releases that have occurred through the pipe, some up to a depth of $1.7 \mathrm{ft}$. The bottom of the culvert and tributary contain a 1- to 3-in. layer of hardened and weathered asphalt and (or) tar. The bitumen material does not appear to have been deliberately placed as a liner, because of its highly uneven covering in the tributary channel.

Area 3 is located in a heavily wooded, low-lying area downgradient and east of the Ft. Bragg property boundary. Area 3 includes the eastern tributary and an adjacent ground-water seepage area. The tributary flows northeast toward Tank Creek. The land elevation in this area is about $230 \mathrm{ft}$ asl.

Area 4 is the site of an asphalt or tar disposal area located just west of Building 31949 in the northeastern part of the JSOC (fig. 6). The disposal area covers about $100 \mathrm{ft}^{2}$ and appears to be the result of the past disposal of end-of-day excess material. Area 4 is situated on the edge of a plateau which slopes to the north into a drainage swale about $150 \mathrm{ft}$ downgradient of this area. Rainfall runoff from Area 4 flows into this swale, and passes under Hurst Drive through a concrete culvert. Runoff from the swale empties into a wetland area out of which flows a perennial tributary to Tank Creek.

A RCRA-regulated DPWE storage compound, SWMU 63, is located adjacent to the DAP (fig. 2). This SWMU was used to store various hazardous wastes above ground from 1977-82, including PCB wastes, acids, caustics, solvents, paint wastes, waste oil, photographic wastes, and pesticides. Wastes were removed and the unit was closed in 1982 because of improper leakage controls. No contaminant releases were documented at this site (S.J. Macmull, Ft. Bragg, N.C., written commun., 1991). The SWMU 63 is located upgradient from part of the study area.

\section{Physical and Chemical Characteristics of Source Materials}

There is evidence of coal tar and (or) raw asphalt in the study area. Coal tar is a thick, black or brownish liquid or semi-solid and produces a naphthalene-like odor. Coal tar is a by-product of the destructive distillation of coal to produce coke or synthetic natural gas. The composition of coal tar varies, but generally consists of 2- to 8-percent light oils (with benzene, toluene, and xylene the main ingredients), 8- to 10-percent middle oils (with phenols, cresols, and naphthalene the main ingredients), 8- to 10-percent heavy oils (with naphthalene and derivatives the main 
ingredients), 16- to 20-percent anthracene oils, and about 50-percent pitch (Gosselin and others, 1976). The specific gravity of coal tar is about 1.18 to 1.23 (Hawley, 1981), and it is only slightly soluble in water.

Quinn and others (1985) reported a number of organic chemicals occurring in a commercial coal tar sample (table 1). Their data only provide an example of compounds and concentrations in coal tar or bitumen, because each batch of tar is unique in its chemical composition.

Raw asphalt forms a deep black, shining brittle mass, or a dark-brown to black cement material of a solid or semi-solid consistency. Asphalt is a complex, thermoplastic mixture of high-molecular weight hydrocarbons with small amounts of sulfur, nitrogen, and oxygen compounds. Asphalt is made from crude petroleum by a distillation process in which lighter hydrocarbons are evaporated and the residue is partially oxidized.

Asphalt generally is produced either by blowing air at high temperature through petroleum crude (air-blown or oxidized asphalt) or by fluxing the crude base with suitable distillates such as petroleum (cutback asphalt) and steam (emulsified asphalt) (Sax and Lewis, 1987). Typical asphalt has a specific gravity of 1.00 to 1.18 , and is relatively insoluble in water, alcohol, acids, and alkalis (Windholz, ed., 1983). It is unknown whether the DAP processed emulsified, cutback, or oxidized asphalts, or a combination of the three.

The most significant chemical compounds in asphalt and tar are the polynuclear aromatic hydrocarbons (PAHs). Polynuclear aromatic hydrocarbons are compounds with relatively low solubilities and vapor pressures, and high octanol-water partition coefficients (Smith and others, 1987) (table 1). Thus, their tendency is to strongly partition from water into particulate and dissolved organic matter, and organic sediment. Sediment concentrations of PAHs can be several orders of magnitude higher than water concentrations (Smith and others, 1987). In addition to the strong tendency to sorb to sediment, some PAHs have been shown to biodegrade. Other transport and transformation processes, such as volatilization and hydrolysis, are not important fate processes. Polynuclear aromatic hydrocarbons are derived from natural and anthropogenic sources, but their occurrence in water is believed to stem primarily from anthropogenic inputs (Cossa and others, 1983). These compounds are produced during high-temperature incineration such as that found in manufacturing processes, municipal incineration, and forest fires. Smith and others (1987) reported that PAH residues in soils are typically higher in highly populated, industrialized areas.

\section{DATA COLLECTION AND ANALYSIS}

Standard drilling and sampling methods were used to investigate the hydrogeology and potential contamination in the study area. These methods were defined in the workplan for Ft. Bragg SWMU's (S.J. Mackmull, Ft. Bragg, N.C., written commun., 1991), and were approved for use in the RFI field work by the North Carolina Department of Environment, Health, and Natural Resources and the USEPA. Study methods generally followed those in the RFI work plan in order to maintain consistency with ongoing RCRA work and to ensure scientifically and legally defensible data. 
Table 1.--Organic compounds in commercial roofing tar and raw bitumen samples, and experimentally determined octanol-water partition coefficients, solubilities, and vapor pressures

[ND, not detected; --, no data available; NA, not applicable; $\mathrm{K}_{\mathrm{ow}}$, octanol-water coefficient; $\mathrm{mg} / \mathrm{L}$, milligrams per liter; ${ }^{\circ} \mathrm{C}$, degrees Celsius; mm, millimeters; $\mathrm{Hg}$, mercury; $\mu \mathrm{g} / \mathrm{kg}$, microgram per kilogram; $\mu \mathrm{g} / \mathrm{g}$, microgram per gram ]

\begin{tabular}{|c|c|c|c|c|c|}
\hline Organic Compounds & $\begin{array}{l}\text { Commercial } \\
{\text { roofing } \operatorname{tar}^{1}}^{1}\end{array}$ & $\begin{array}{c}\text { Raw } \\
\text { bitumen }\end{array}$ & $\begin{array}{l}\log ^{3} \\
K_{\text {ow }}\end{array}$ & $\begin{array}{c}\text { Solubility }{ }^{3} \\
\text { (mg/L at } \\
\left.25^{\circ} \mathrm{C}\right)\end{array}$ & $\begin{array}{c}\text { Vapor } \\
\text { pressure } \\
(\mathrm{mm} \text { of } \mathrm{Hg} \\
\left.\text { at } 20^{\circ} \mathrm{C}\right)\end{array}$ \\
\hline \multicolumn{6}{|c|}{$\begin{array}{c}\text { Volatiles } \\
\text { ( } \mu \mathrm{g} / \mathrm{kg} \text { wet weight) }\end{array}$} \\
\hline Benzene & ND & - & 2.13 & 1,780 & 76 \\
\hline Ethylbenzene & ND & -- & 3.15 & 152 & 7 \\
\hline Toluene & ND & - & 2.69 & 470 & 22 \\
\hline Styrene & ND & -- & -- & -- & - \\
\hline Xylenes & ND & -- & 2.77 & 175 & 5 \\
\hline Detection limits & 500 & -- & NA & NA & NA \\
\hline
\end{tabular}

Semivolatiles

( $\mu \mathrm{g} / \mathrm{kg}$ wet weight)

\begin{tabular}{lrlllr}
\hline Acenaphthene & ND & -- & - & - & - \\
Fluoranthene & 19,000 & -- & -- & -- & - \\
Naphthalene & ND & -- & 3.37 & 34.4 & 0.0492 \\
2-methylnaphthalene & ND & -- & -- & -- & - \\
Bis(2-ethylhexyl)phthalate & ND & -- & -- & -- & - \\
Benzo(a)anthracene & 11,000 & $130-860$ & 5.61 & .014 & $5 \times 10^{-9}$ \\
Benzo(a)pyrene & 15,000 & -- & 6.04 & .0038 & $5 \times 10^{-9}$ \\
Benzo(b)fluoranthene & 9,200 & -- & -- & -- & -- \\
Benzo(k)fluoranthene & 6,500 & $340-1,410$ & -- & -- & $9.59 \times 10^{-11}$ \\
Chrysene & 10,000 & $1,640-5,140$ & 5.61 & .002 & -- \\
Fluorene & ND & -- & -- & -- & -
\end{tabular}


Table 1.--Organic compounds in commercial roofing tar and raw bitumen samples, and experimentally determined octanol-water partition coefficients, solubilities, and vapor pressures--Continued

[ND, not detected; --, no data available; NA, not applicable; $\mathrm{K}_{\mathrm{ow}}$, octanol-water coefficient; $\mathrm{mg} / \mathrm{L}$, milligrams per liter; ${ }^{\circ} \mathrm{C}$, degrees Celsius; mm, millimeters; $\mathrm{Hg}$, mercury; $\mu \mathrm{g} / \mathrm{kg}$, microgram per kilogram; $\mu \mathrm{g} / \mathrm{g}$, microgram per gram ]

\begin{tabular}{|c|c|c|c|c|c|}
\hline Organic Compounds & 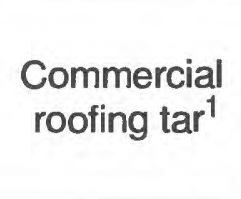 & $\begin{array}{c}\text { Raw } \\
\text { bitumen }\end{array}$ & $\begin{array}{l}\log ^{3} \\
\mathrm{~K}_{\text {ow }}\end{array}$ & $\begin{array}{c}\text { Solubility }^{3} \\
\text { (mg/L at } \\
\left.25^{\circ} \mathrm{C}\right)\end{array}$ & $\begin{array}{c}\text { Vapor } \\
\text { pressure } \\
\text { (mm of } \mathrm{Hc} \\
\text { at } 20^{\circ} \mathrm{C} \text { ) }\end{array}$ \\
\hline \multicolumn{6}{|c|}{$\begin{array}{l}\text { Semivolatiles--Continued } \\
\text { ( } \mu \mathrm{g} / \mathrm{kg} \text { wet weight) }\end{array}$} \\
\hline Acenaphthylene & 890 & -- & -- & - & -- \\
\hline Anthracene & 6,100 & -- & 4.45 & .045 & $1.95 \times 10^{-4}$ \\
\hline Dibenzo(a,h)anthracene & ND & -- & - & -- & -- \\
\hline Phenanthrene & 20,000 & -- & 4.46 & 1.0 & $6.8 \times 10^{-4}$ \\
\hline Pyrene & 15,000 & $170-800$ & - & .14 & $6.85 \times 10^{-7}$ \\
\hline Benzo(ghi)perylene & 3,900 & - & - & .00026 & -- \\
\hline Ideno(1,2,3-cd)pyrene & 3,800 & -- & - & - & - \\
\hline Dibenzofuran & ND & -- & - & - & - \\
\hline Phenol & ND & -- & - & -- & -- \\
\hline Detection Limits & 210 & - & NA & NA & NA \\
\hline
\end{tabular}

${ }^{1}$ From Quinn and others, 1985

${ }^{2}$ From Verschureren, K., 1983

${ }^{3}$ From Callahan and others, 1979

\section{Site Screening for Potential Contaminants}

Surface geophysics and soil-gas sampling were used to screen areas for potential contamination. These techniques were intended to reveal relatively large and concentrated sources of contamination that may have been missed by visual reconnaissance, base-planning documents, and discussions with base personnel. Screening results were used to determine locations for monitoring-well installation, and soil and water sampling. 


\section{Surface-Geophysical Surveys}

Surface-geophysical surveys were performed in Areas 1, 2, and 4 to identify subsurface anomalies attributable to lithologic changes or to buried drums or other sources of contamination. Surface geophysics also were used in the north-central section of JSOC, an area that contained one, half-buried drum originally believed to be associated with the DAP (fig. 2). Surfacegeophysical surveys were not conducted in part of Area 2, because of the large number of metallic objects in the area (fencing, steel parts, and miscellaneous metal rubble). Surface-geophysical surveys also were not conducted in Area 3 due to the high density of trees and ground cover.

Two surface-geophysical techniques were used in the study area: electromagnetic induction and ground penetrating radar (GPR). The electromagnetic-induction survey was conducted on January 4, 1993 and February 9, 1993, using a Geonics EM-31 instrument. The EM-31 is a handheld instrument that measures the interference of electromagnetivity between a sending coil and a receiving coil, spaced about $6 \mathrm{ft}$ apart. Interferences caused by changes in subsurface conductivity are measured to a depth of up to $15 \mathrm{ft}$. Subsurface conductivity varies with the presence of changing lithologies, nearby and underground utilities, and buried objects, such as drums or landfill material. The EM-31 instrument was calibrated at a designated background site prior to use. The GPR emits high-frequency electromagnetic waves that penetrate into the subsurface and reflect back to the instrument when dielectric constant differences are encountered.

The primary purpose of the EM-31 and GPR techniques was to determine whether a cluster of drums was located in the subsurface sediment of the study area. It was recognized that surface geophysical surveys often reveal small, localized subsurface anomalies attributable only to miscellaneous rubble or other innocuous material. Keeping this in mind, the technique was used to survey areas of potentially larger anomalies such as clusters of buried drums.

Results of the EM-31 survey include quadrature phase data and inphase data. The quadrature phase is used in the measurement of the apparent conductivity of the soil and its contents, and is measured in millisiemens per meter $(\mathrm{mS} / \mathrm{m})$. The inphase is used in the measurement of the presence of buried metal debris and (or) materials that cause an ionic differential. Inphase is measured in parts per thousand (ppt).

Data from the EM-31 technique were collected February 9, 1993 (fig. 8). Quadrature and inphase results for several lines of EM-31 data collected in Areas 1, 2, and 5 ranged from 0 to 44 $\mathrm{mS} / \mathrm{m}$ and from off-scale negative values to $18 \mathrm{ppt}$, respectively. Regions of Area 1 that contain anomalous quadrature or inphase readings are believed to be attributed to either distinctive changes in soil type (sands to clays, for example) or to buried rubble associated with the asphaltplant operation or demolition. An EM-31 signature suggesting the presence of a large cluster of buried drums or a large area of fill or disposal material was not observed in the measured areas.

The GPR survey was made on December 12, 1992, using the Geophysical Survey Systems SIR 80 instrument (fig. 9). Data from these surveys suggest the presence of what appear to be about two buried drums in Area 4, adjacent to the asphalt- or tar-spill area. Otherwise, the surveys did not indicate buried drums in any of the studied areas, including the vicinity of the single, half-buried drum on JSOC. 


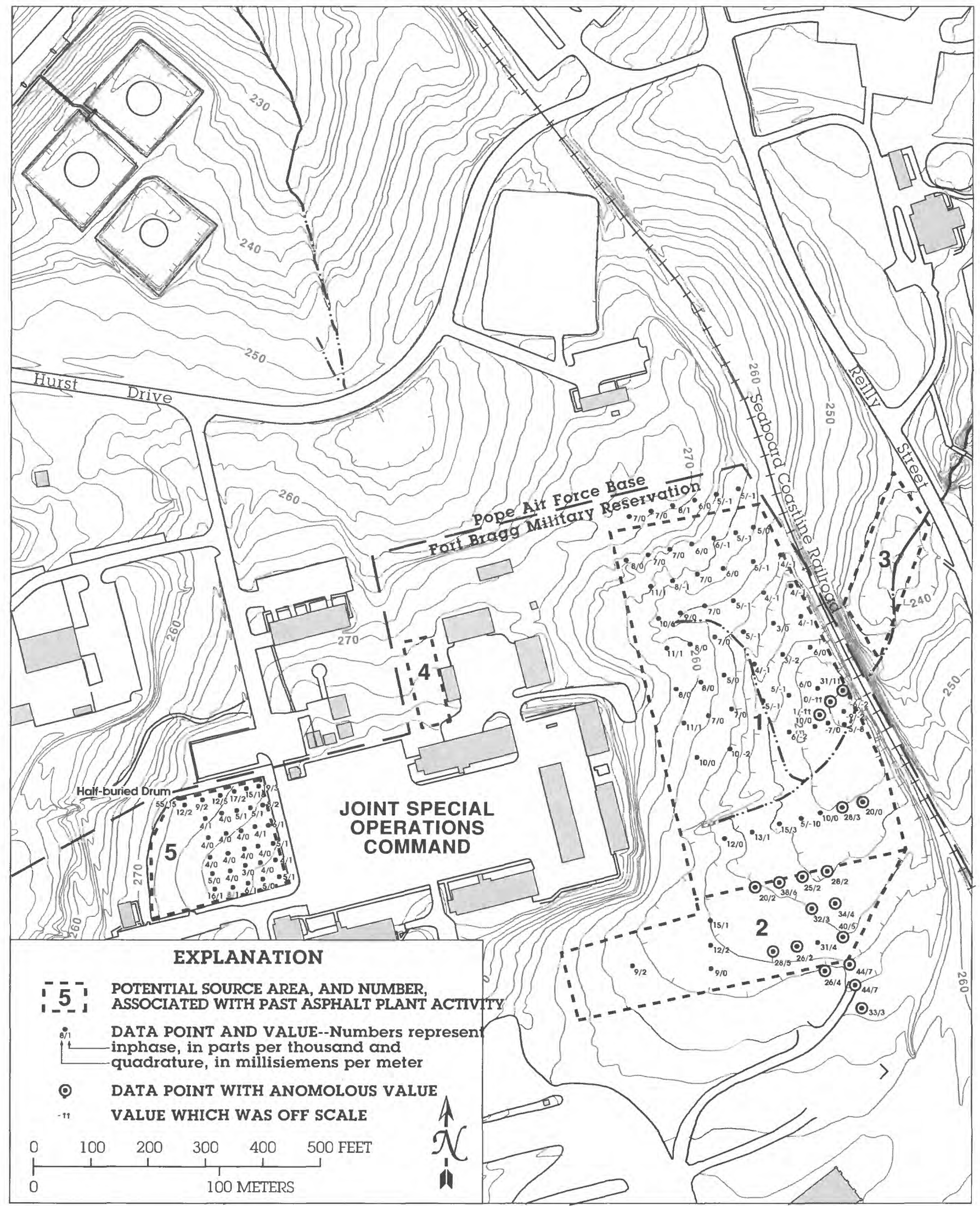

Figure 8. Quadrature and inphase results of EM-31 survey made in areas 1 and 2 on February 9, 1993, and in area 5, January 4, 1993. 


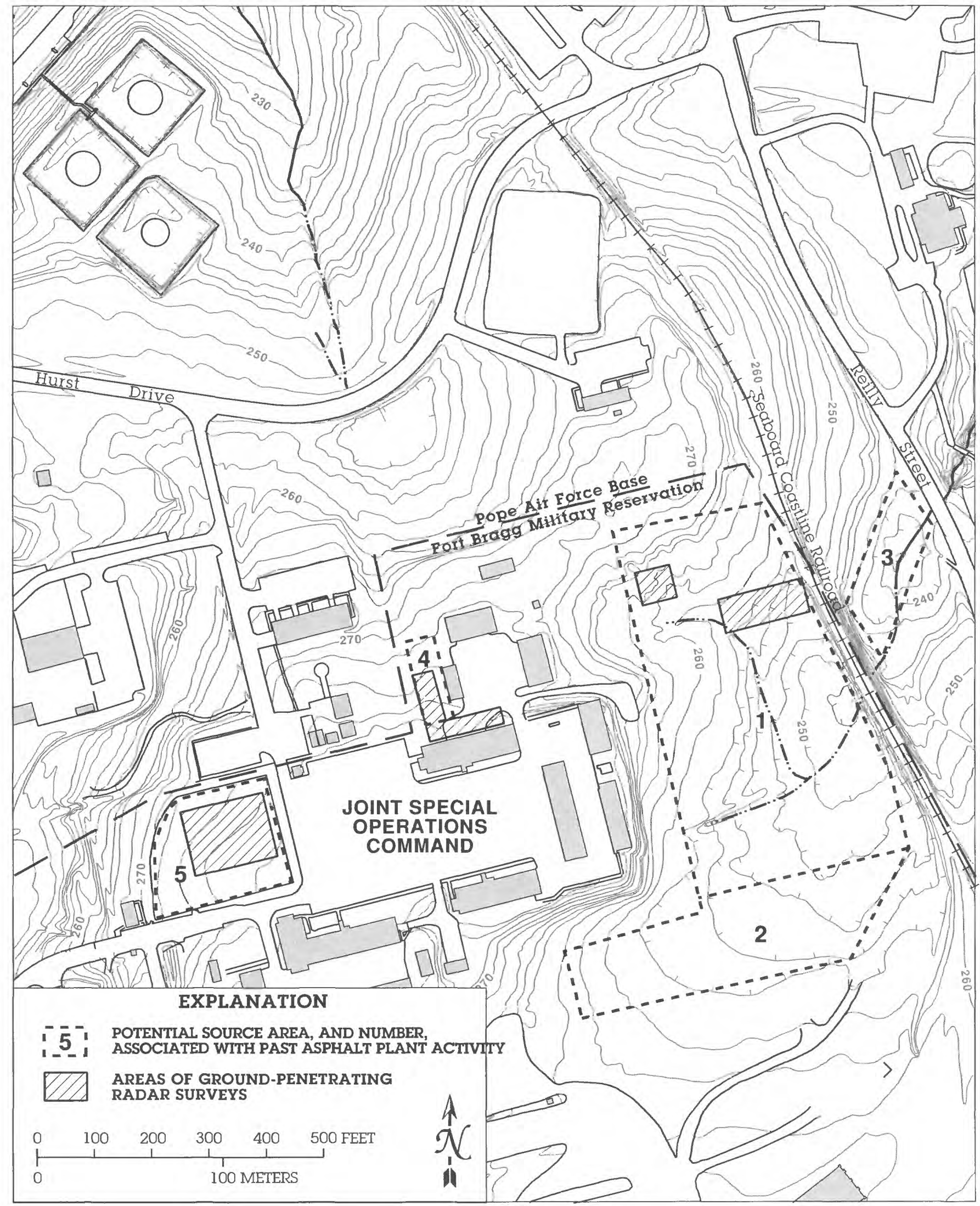

Figure 9. Ground-penetrating radar survey locations in areas 1, 4, and 5, December 12, 1992. 


\section{Sampling for Volatile Organic Compounds in Soil Gas}

Soil-gas sampling was used to screen large areas of the study area for volatile organic compounds (VOCs). The technique was used primarily to detect VOCs in the unsaturated zone, because the water table was located at depths ranging from 12 to $35 \mathrm{ft}$ bls. Volatile organic compounds in the unsaturated zone represent areas of soil contamination that may have resulted from surface spillage or from the disposal of site-related volatile chemicals.

Soil-gas samples were collected at a depth of about $2 \mathrm{ft}$ using a 1-in.-diameter slide hammer, a suction pump and probe, and Teflon collection bags. Samples were drawn into the collection bags with the aid of a suction pump. The suction withdraws VOCs from the soil particles and pore spaces between soil particles in the area near the probe tip. A gas chromatograph was used to analyze the samples for VOCs that were collected in each bag. The method assumed a relatively uniform soil permeability across the survey grid. This assumption was valid due to the relatively uniform lithology at the sampling depths across the study area.

Seven soil-gas samples were collected at locations across the site as part of site-safety screening procedures (PSARA Technologies, Inc., 1993) (fig. 10). The soil-gas samples did not contain detectable concentrations of VOCs.

Soil-gas samples were also collected on February 23 and 24, 1993, and on June 22, 1993, as part of study area screening. Samples from several locations contained accumulated concentrations of benzene, toluene, ethylbenzene, and xylene (BTEX) that exceeded $5 \mathrm{~mL} / \mathrm{L}$ (fig. 11). These VOCs were used to indicate the potential presence of other contaminants that could be associated with past DAP operations. Duplicate, ambient-air, and equipment-blank samples were collected and analyzed for purposes of quality control.

\section{Monitoring-Well Installation and Development}

Eight monitoring wells were installed between August 26, 1993 and November 1, 1993, to determine site lithology, hydrogeologic characteristics, vertical and lateral extent of soil contamination, and ground-water quality (fig. 6). Of these, seven wells were used for groundwater sampling, and one well was used for water-level measurements. Wells were placed at or downgradient of suspected source areas to intercept ground water that could migrate off-site. All wells were screened in a 10-ft interval in the surficial aquifer to depths ranging from about 25 to $70 \mathrm{ft}$ bls. Of the eight wells installed, six were screened at the top of the water table and two were screened in a lower zone of the surficial aquifer just above a clay layer at least $4 \mathrm{ft}$ thick that is believed to be part of a transitional zone of the upper Cape Fear confining unit. Wells designated by an "S" (for example, MW.DAP3S) were screened in the shallow part of the surficial aquifer, and wells designated by a "D" (for example, MW.DAP3D) were screened in the deeper part (fig. 6). Wells were installed at five locations at or downgradient of potential sources of contamination. At two locations, a shallow well and a deeper well were clustered. The shallow wells were intended to intercept chemicals with aqueous densities less than or near that of water, whereas the deeper wells were intended to intercept the more dense, non-aqueous phase liquids or other heavy, long-chained compounds. 


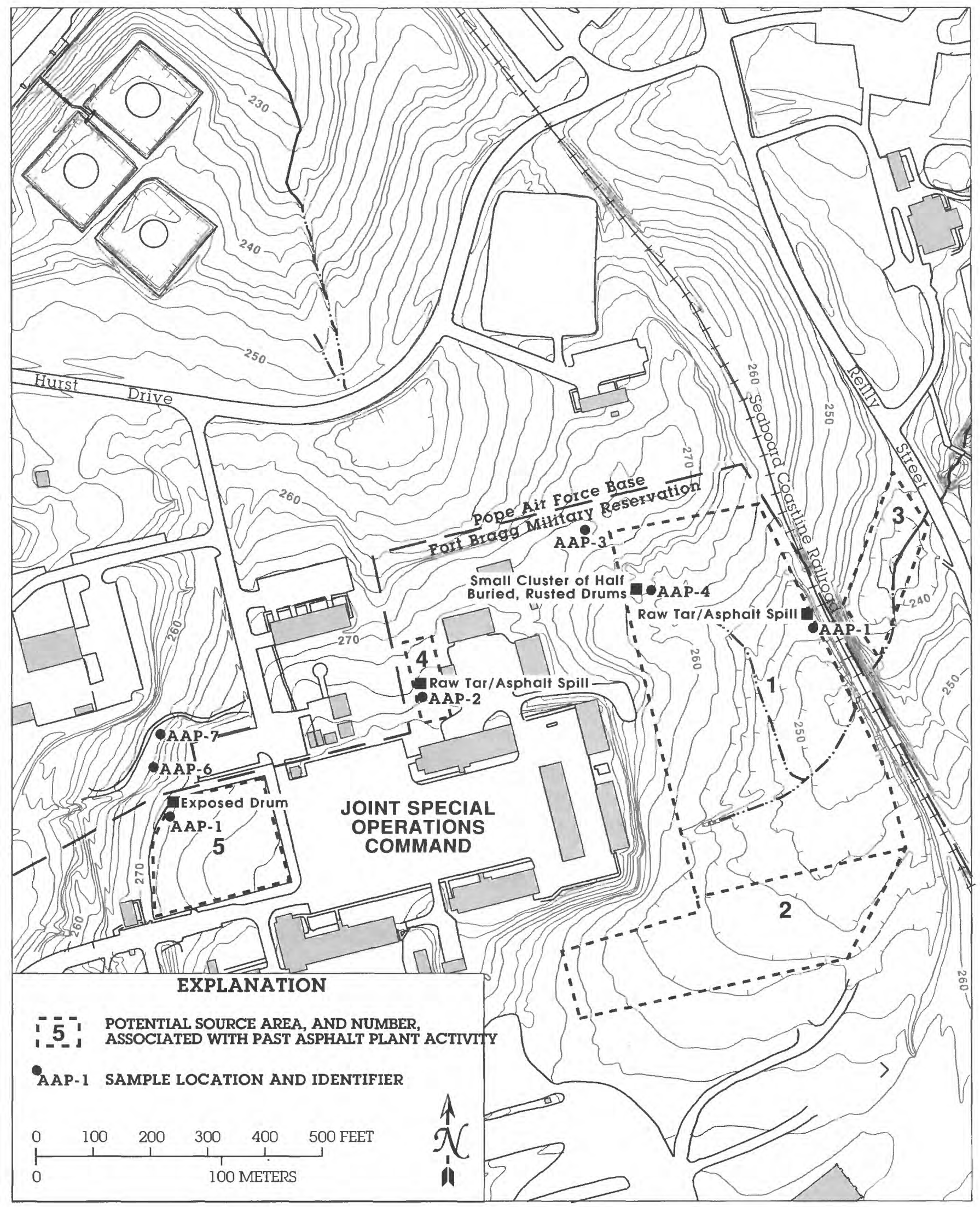

Figure 10. Site-safety screening soil-gas and soil-boring sample locations, December 15-17,1992. 


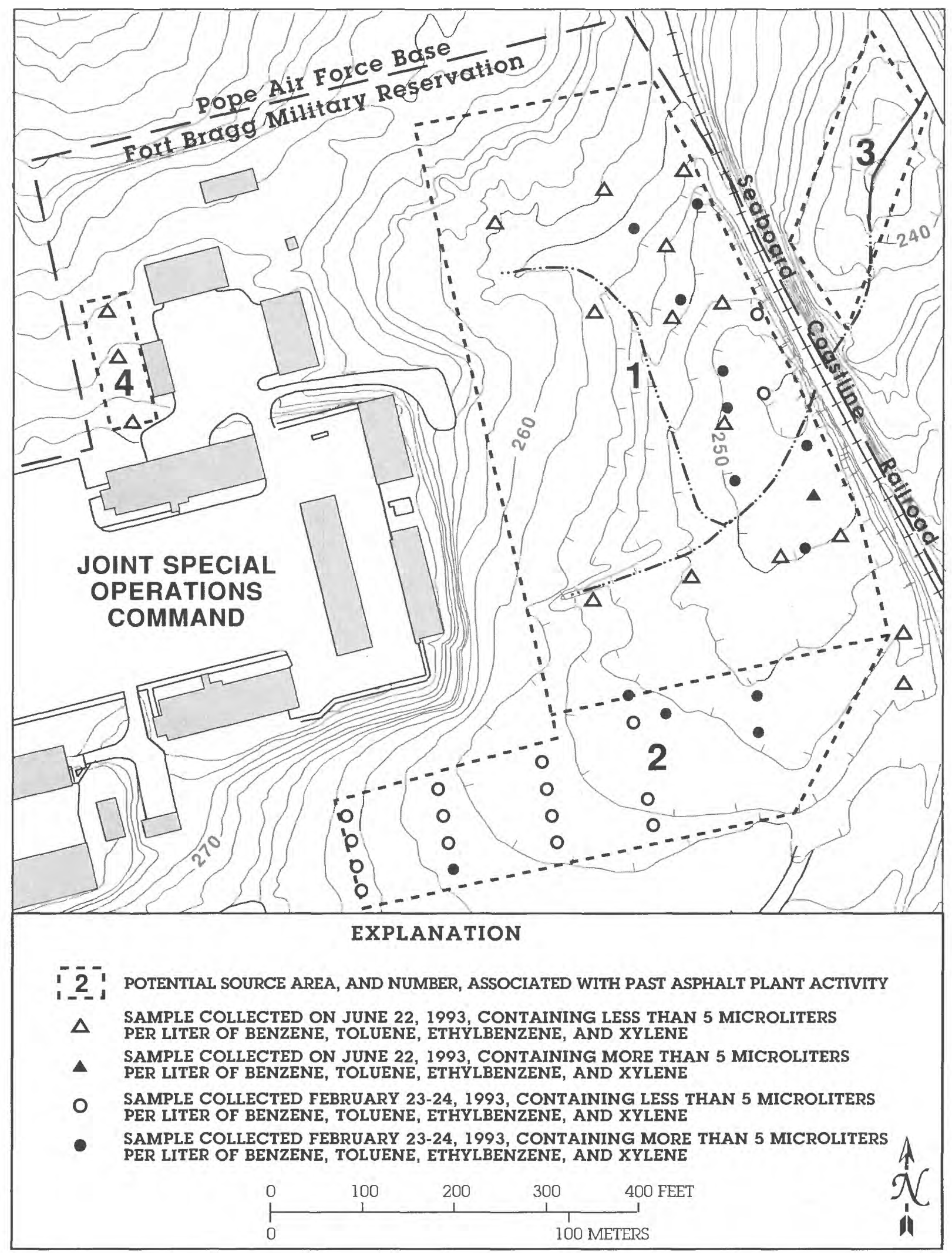

Figure 11. Soil-gas sample locations, February 23 - 24, 1993 and June 22, 1993. 
Monitoring wells MW.DAP1S, MW.DAP2S1, MW.DAP2S2, MW.DAP3S, MW.DAP4S, and MW.DAP5S were screened across the August 1993 water table with about $2 \mathrm{ft}$ of the $10-\mathrm{ft}$ screen extended into the unsaturated zone above the water table. Monitoring wells MW.DAP3D and MW.DAP4D were deeper wells and were screened in the lower part of the surficial-flowsystem, just above the clays of the upper Cape Fear confining unit.

Wells were drilled using 6.25-in. inside-diameter hollow-stem augers. The drill rig and augers were steam cleaned prior to use at each well location. Well cuttings were placed in 55 -gallon drums and later disposed in accordance with regulatory criteria as stated in the workplans (S.J. Mackmull, Ft. Bragg, N.C., written commun., 1991).

During drilling, soil cores were collected every $5 \mathrm{ft}$ or less using stainless-steel split-spoon samplers. Before use, the split-spoons were decontaminated with deionized water, laboratorygrade detergent, and isopropanol. Blow counts were recorded for each split-spoon interval, and the soil cores were lithologically described (appendix 2). The cores were placed in sealed containers for later on-site analysis of VOCs using a portable organic-vapor analyzer.

Wells were constructed using 4-in. inside-diameter Schedule 40 flush-threaded polyvinyl chloride (PVC) pipe. Well screens contained 0.010-in. machined slots, were 10-ft long, and were pre-packed with filter sand. Well materials arrived on-site in protective plastic or were steam cleaned prior to downhole placement. Once the well casing was lowered in place, filter sand was added to the annular space to a level about $2 \mathrm{ft}$ above the top of the well screen. A 2- to 5-ft layer of bentonite pellets was then placed above the filter sand to prevent vertical migration of cement or chemical leachate from overlying zones. Cement grout was added to the annular space from the top of the bentonite plug to near ground surface. A protective steel casing with locking cap was placed over the riser pipe, and a 4-ft by 4-ft concrete pad was poured around the well (fig. 12). Well-construction details and water-level elevations for the monitoring wells are shown in table 2.

Borehole-geophysical techniques were used to augment the lithologic information obtained from split-spoon sampling. These data were used to define the stratigraphy and determine appropriate well-screen depths in subsequent holes. Gamma-ray logs were made for 5 wells (appendix 1).

After construction and a minimum set time of two weeks, the wells were developed. During development, ground-water temperature, $\mathrm{pH}$, specific conductance, and estimated turbidity were measured at intervals of about 5 minutes or less. Well development was considered complete only after ground-water measurements had stabilized and ground-water samples had become clear. After the development of each well, all downhole equipment was decontaminated with deionized water and laboratory-grade detergent.

\section{Determination of Aquifer and Confining-Unit Properties}

Laboratory analyses of selected lithologic core samples were used to determine soil characteristics and to estimate vertical hydraulic conductivities. Laboratory soil analyses included grain-size distribution, porosity, moisture content (American Society for Testing Materials (ASTM) D2216), dry density, specific gravity (ASTM D854), Atterburg limits (ASTM D4318), and on selected cores, falling-head permeameter tests for hydraulic conductivity computations (American Society for Testing Materials, 1992). 


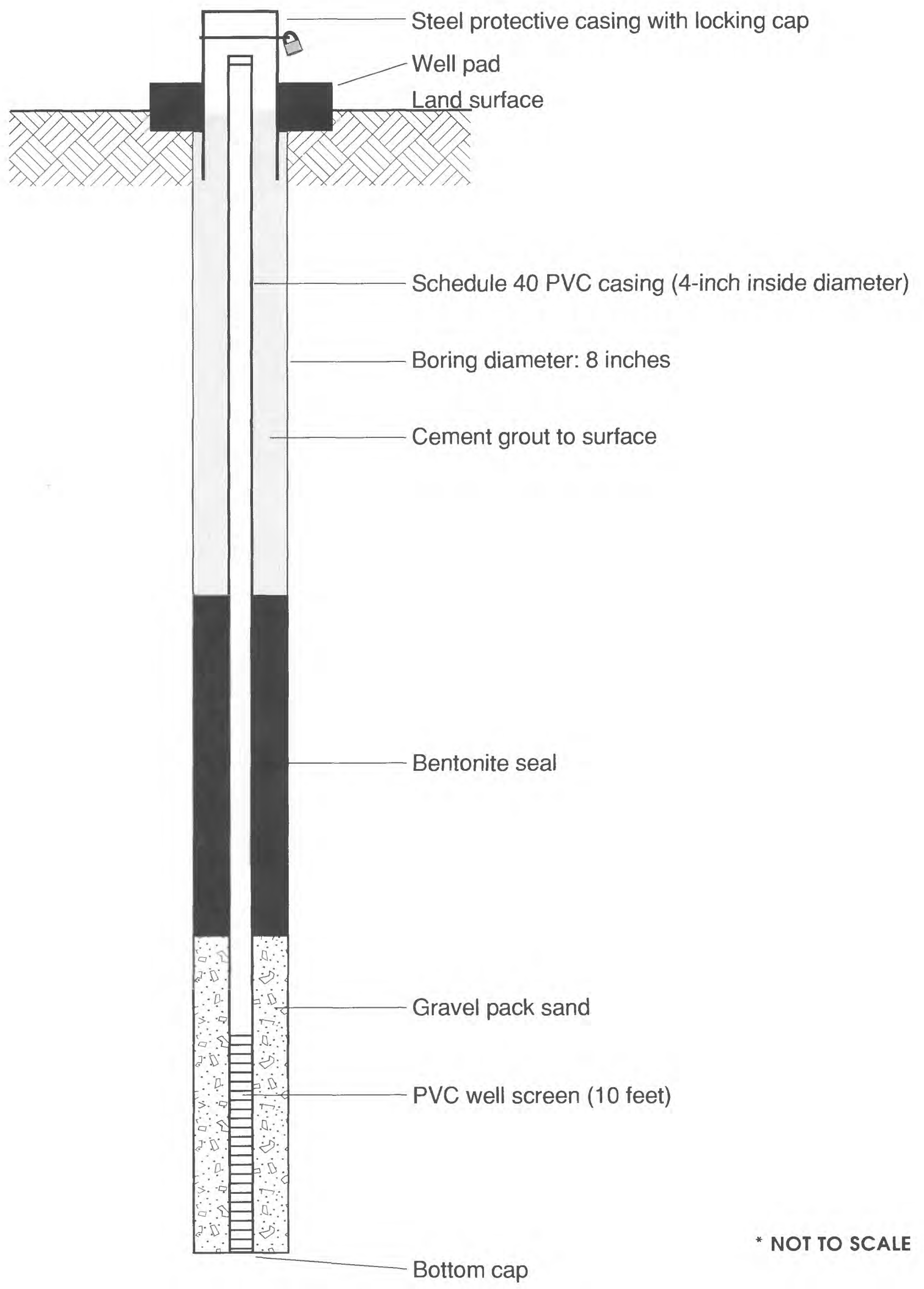

Figure 12. Monitoring-well design. 


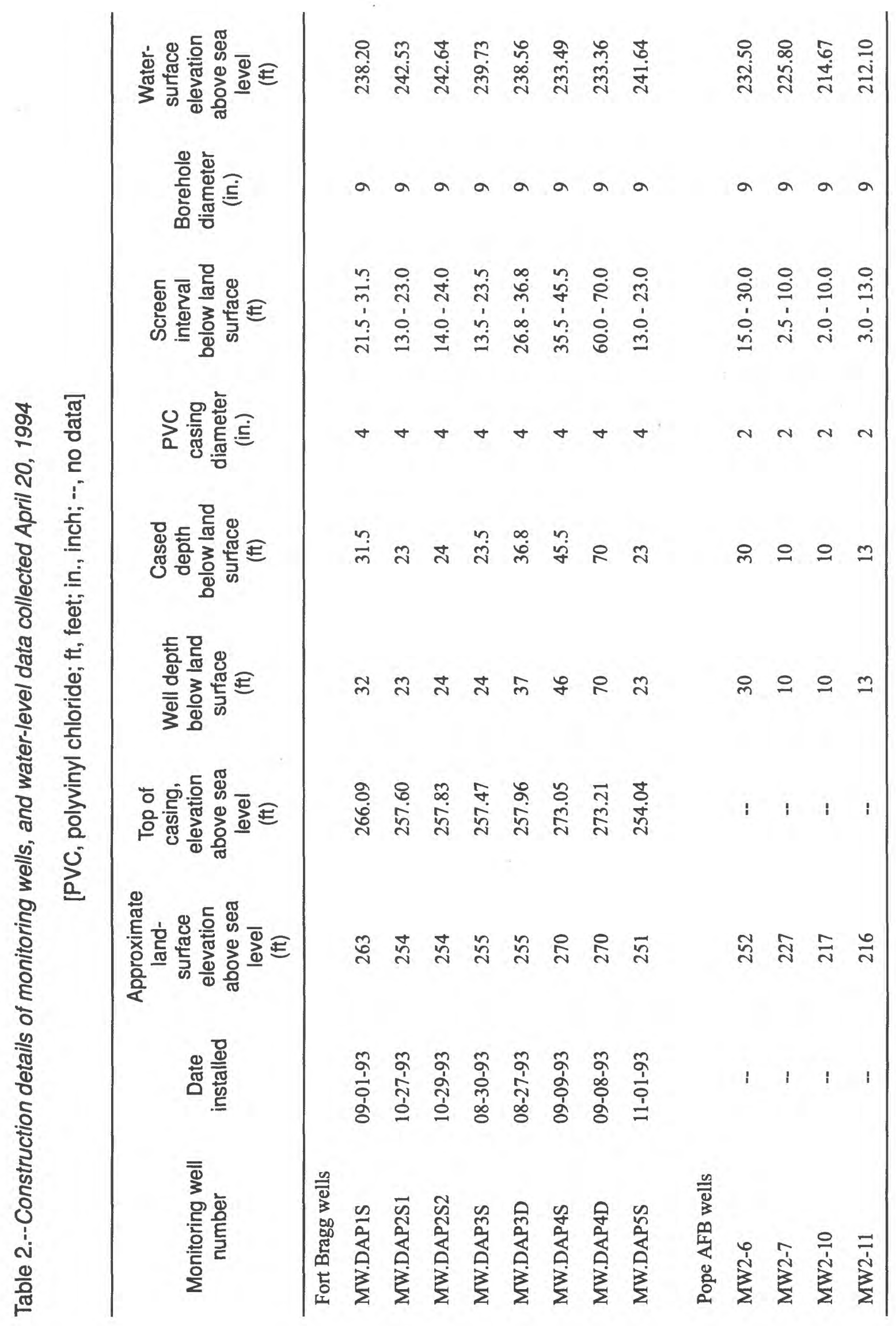


The results of two aquifer tests were used to estimate horizontal hydraulic conductivities. Rising-head slug tests were conducted on wells MW.DAP3D and MW.DAP4D. Once stabilized, water was removed from the well using a 3.25-in. inside-diameter bailer. Water levels were recorded using a portable, digital-data logger, and pressure transducer. The bailer and pressure transducer were cleaned with deionized water and laboratory-grade detergent after each test. The slug tests were performed after the collection of ground-water samples. Slug-test methods and computations followed those described in Bouwer and Rice (1976). Slug tests performed at wells MW.DAP4D and MW.DAP3D resulted in average horizontal hydraulic conductivity values of 2 and $0.2 \mathrm{ft} / \mathrm{d}$, respectively (appendix 3 ).

In addition to the hydraulic conductivities computed from the DAP slug tests, hydraulic conductivities from nearby Pope AFB wells were obtained from the existing literature (Remedial Investigation Report, 1993). The estimated average horizontal hydraulic conductivities from slug tests at MW.DAP4D $(\mathrm{K}=2 \mathrm{ft} / \mathrm{d})$ and MW.DAP3D $(\mathrm{K}=0.2 \mathrm{ft} / \mathrm{d})$, and from three nearby wells at Pope AFB (average $K=8 \mathrm{ft} / \mathrm{d}$ ), were averaged to obtain an estimate of the hydraulic conductivity. The average horizontal hydraulic conductivity was estimated to be about $5 \mathrm{ft} / \mathrm{d}$. Although heterogeneities in the subsurface result in varying hydraulic conductivities across the site, this average value was useful in estimating the ground-water-flow velocity.

The horizontal hydraulic conductivity value was used to determine the ground-water-flow rate (average linear velocity) in the area of the DAP using the following equation:

$$
\mathrm{v}=\mathrm{K} / \mathrm{n}(\mathrm{dh} / \mathrm{dl})
$$

where $\mathbf{v}=$ average linear velocity, in feet per day; $\mathrm{K}=$ hydraulic conductivity, in feet per day; $\mathrm{dh}=$ change in hydraulic head between two wells, in feet; $\mathrm{dl}=$ distance between two measured wells, in feet; and $n=$ porosity (dimensionless). Based on typical values listed in Freeze and Cherry (1979), a porosity value of 0.35 was assumed for the study area substrate. Based on observed water levels across the site, the value of $\mathrm{dh} / \mathrm{dl}$ was estimated to be $0.007 \mathrm{in}$ the direction of principal ground-water flow from the southeast to the northwest. The horizontal ground-waterflow rate was estimated to be $0.10 \mathrm{ft} / \mathrm{d}$, or about 35 feet per year ( $\mathrm{ft} / \mathrm{yr}$ ).

Hydraulic conductivities used to evaluate vertical ground-water movement were computed from laboratory falling-head permeability tests. These tests were conducted on cores from clayey zones with expected low permeability and from cores of clayey sand. The results of vertical hydraulic conductivity tests ranged from 0.017 to $0.000117 \mathrm{ft} / \mathrm{d}$.

According to geotechnical laboratory test results, the 1- to 2-ft layer of gray plastic clay encountered at about $14 \mathrm{ft}$ bls at wells MW.DAP3S and MW.DAP3D was characterized as a sandy clay, and had an Atterburg Limit for plasticity of 57.9 (liquid limit) and 33.9 (plasticity index). These levels generally correspond to a vertical hydraulic conductivity range of between $3 \times 10^{-3}$ and $3 \times 10^{-5} \mathrm{ft} / \mathrm{d}$. Geotechnical laboratory results characterized a sample of sediment from the zone between about 16 and $38 \mathrm{ft}$ bls as a non-plastic silty sand having a vertical hydraulic conductivity of $1.7 \times 10^{-2} \mathrm{ft} / \mathrm{d}$. Four feet of gray plastic clay comprised the sediment at the bottom of the wells; the geotechnical laboratory results characterized the clay as a sandy clay with slightly lower plasticity than the clay layer located at $14 \mathrm{ft}$ bls. The liquid limit was 22.2 and the plasticity index was 12.4. The material from about 54 to $58 \mathrm{ft}$ bls at well MW.DAP1S was characterized as a non-plastic silty sand. 
The material from 10 to $30 \mathrm{ft}$ bls at wells MW.DAP4S and MW.DAP4D was characterized as a fine sand, and had a liquid limit of 27.0 and a plasticity index of 15.8. The falling-head permeameter test yielded a vertical hydraulic conductivity of $1.2 \times 10^{-4} \mathrm{ft} / \mathrm{d}$. The relatively low hydraulic conductivity can be explained by the presence of plastic clay which, in effect, acts as a binder within the fine sand unit. Test results characterized the material at the bottom of the borings, at about $70 \mathrm{ft}$ bls, as a non-plastic silty, fine to coarse sand.

\section{Water-Level Measurements}

Water-level elevations were obtained to determine ground-water-flow patterns in the study area. Water-level measurements were obtained from monitoring wells on April 20, 1994 (table 2). Water levels were measured using an electric water-level indicator, and were recorded to the nearest $0.01 \mathrm{ft}$. Each measurement was repeated until two identical readings were obtained. Each reading was referenced to the top of the PVC-well casing. The elevation of the top of casing, relative to sea level, was determined using first-order leveling. After each water-level measurement, the electric water-level indicator was decontaminated using deionized water and laboratory-grade detergent.

\section{Chemical Sampling and Analysis}

Source material, soil, ground-water, surface-water, and streambed-sediment samples were collected in the study area and analyzed in the laboratory for a number of chemical compounds. These data provided quantitative information on the chemical quality of study area media. Further, these data allowed for a comparison of study area chemical concentrations with those listed as USEPA maximum contaminant levels (MCLs) (U.S. Environmental Protection Agency, 1991).

\section{Source Materials}

Source materials (asphalt, tar, or a related substance) were collected in each of the four study areas of the DAP (fig. 13). To assure a representative sample from each area, several subsamples were collected and composited into a single sample for that area. In all, four composited source samples were collected. In Area 1, material was collected and composited from various asphalt piles, the bitumen spill, and drum contents. In Area 2, stained soil was collected and composited from a depth of about 0.5 to $2.0 \mathrm{ft}$ in the area of the asphalt trench. In Area 3, material was collected and composited from the bitumen layer along the tributary and near the top of the railroad track mound. Because of its physical similarity to material from Area 3, material from the easternmost part of Area 1 was included with Area 3 samples (fig. 13). In Area 4, material was collected and composited from the asphalt- or tar-spill location. A decontaminated stainlesssteel auger or spoon was used to collect the samples. After compositing, the samples were iced and shipped to the laboratory for chemical analyses. 


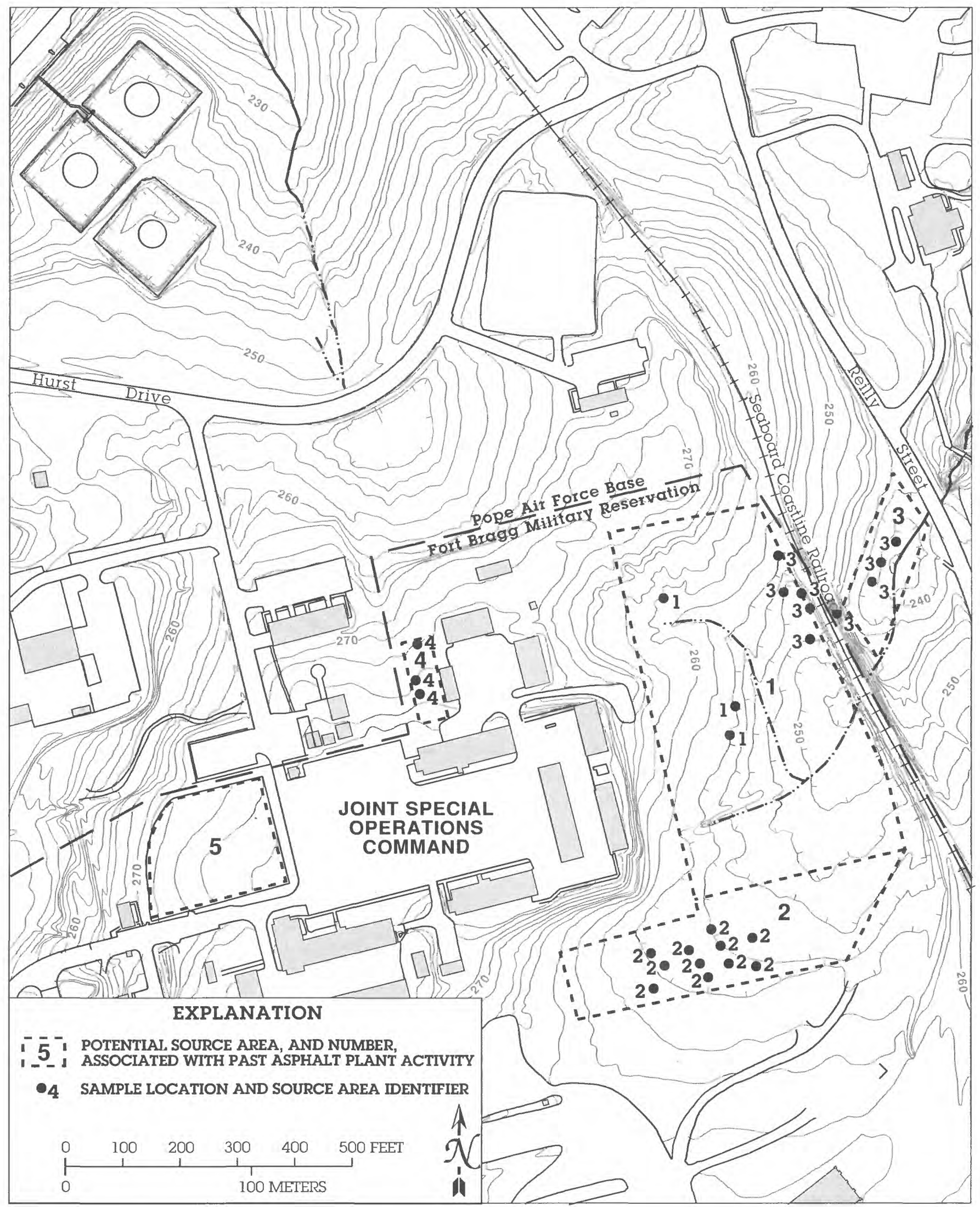

Figure 13. Source-material sample locations, June 29-30, 1993. 
The four composited samples were analyzed for the list of chemicals included in the toxic characteristics leachate procedure (TCLP) and the RCRA hazardous-waste characterization procedure (table 3). The sample preparation procedure used in the TCLP method simulates the conditions of landfill leaching. Therefore, each of the four samples underwent conditions similar to those that would be encountered in a landfill over a number of years, such as precipitation and weathering. The result of this procedure yielded a sample of leachate from each of the four areas. The RCRA hazardous-waste characterization methods determined whether a source was defined as hazardous by the USEPA.

\section{Soil}

Soil samples at the DAP were collected near land surface and, during well drilling, from cores at selected lithologic zones. Soil samples were collected and handled according to procedures outlined in the workplan (S.J. Mackmull, Ft. Bragg, N.C., written commun., 1991). Sampling equipment was decontaminated using deionized water, laboratory-grade detergent, and isopropanol prior to each use. Upon collection, all samples were placed on ice and shipped overnight to the laboratory. Chain-of-custody documents accompanied all samples. The samples were analyzed for VOCs, PAHs, and moisture content (table 4, at the end of the report). Samples for VOC analysis were collected first and sealed quickly to prevent chemical volatilization.

Near-surface soil samples were collected at locations containing the highest soil-gas concentrations, in areas at or adjacent to raw source material, and at locations of monitoring wells (fig. 14). Most samples were collected near, at, or just below source material.

Soil samples were collected from boreholes located at, or just downgradient of, raw source material or past plant activity. The soil samples were collected from selected depths in each borehole (fig. 15). These depths were selected based on headspace readings from containerized soil cores using a portable organic-vapor analyzer, and based on lithologic changes such as interfaces between sand and clay layers, where chemicals may accumulate. Two to four intervals were sampled in the area of each well or well cluster. The following quality-control samples were collected: trip blanks, matrix spikes, matrix-spike duplicates, replicates, and equipment rinsate samples.

\section{Ground Water}

Ground-water samples were collected from seven monitoring wells between February 25, 1994 and March 17, 1994. The sampling procedure consisted of purging the well, measuring field parameters, and collecting, filtering, and bottling samples to be sent to the laboratory for chemical analyses. To ensure a representative ground-water sample, each well was purged of 2 to 4 wellcasing volumes before sampling. Approximate water levels were obtained before purging to determine the volume of water in the well. Wells were purged using a PVC bailer or a stainlesssteel submersible pump. The bailer was decontaminated using deionized water, laboratory-grade detergent, and isopropanol. The submersible pump and discharge tubing were decontaminated using deionized water and laboratory-grade detergent. Each well was sampled on the same day that it was purged. Water levels were allowed to recover before samples were collected. All purged water was contained in 55-gallon drums and later disposed in accordance with regulatory criteria as stated in the work plans. 
Table 3.--Methods used in the analysis of source material samples collected June 2930, 1993 (U.S. Environmental Protection Agency, 1983; 1986a; 1986b; 1986c; 1993a; 1993b)

[EPA, Environmental Protection Agency; TCLP, Toxicity Characteristic Leaching Procedure]

Hazardous waste characterization

Ignitability (EPA Hazardous Waste \#D001)

Corrosivity (EPA Hazardous Wase \#D002)

Reactivity (EPA Hazardous Waste \#D003)

EP-Toxicity (EPA Test Method 1310)

Volatile organic compounds - TCLP Leachate (Method 8240)

Benzene

2-Butanone

Carbon tetrachloride

Chlorobenzene

1,2-Dichloroethane
1,1-Dichloroethene

Tetrachloroethene

Trichloroethene

Vinyl chloride

Semivolatile organic compounds - TCLP Leachate (Method 8270)

1,4-Dichlorobenzene

2,4-Dinitrotoluene

Hexachlorobenzene

Hexachlorobutadiene

Hexachloroethane

2-Methylphenol
3,4-Methylphenol

Nitrobenzene

Pentachlorophenol

Pyridine

2,4,5-Trichlorophenol

2,4,6-Trichloropheno 
Table 3.--Methods used in the analysis of source material samples collected June 2930, 1993 (U.S. Environmental Protection Agency, 1983; 1986a; 1986b; 1986c; 1993a; 1993b)--Continued

[EPA, Environmental Protection Agency; TCLP, Toxicity Characteristic Leaching Procedure]

Chlorinated pesticides - TCLP Leachate (Method 8080)

Aroclor 1016

Aroclor 1221

Aroclor 1232

Aroclor 1242

Aroclor 1248

Aroclor 1254

Aroclor 1260
Gamma-BHC

Chlordane

Endrin

Heptachlor

Toxaphene

Chlorinated herbicides - TCLP Leachate (Method 8150)

2,4-D

2,4,5-TP

Inorganics - TCLP Leachate

Arsenic

Lead

Barium

Mercury

Cadmium

Selenium

Chromium

Silver 


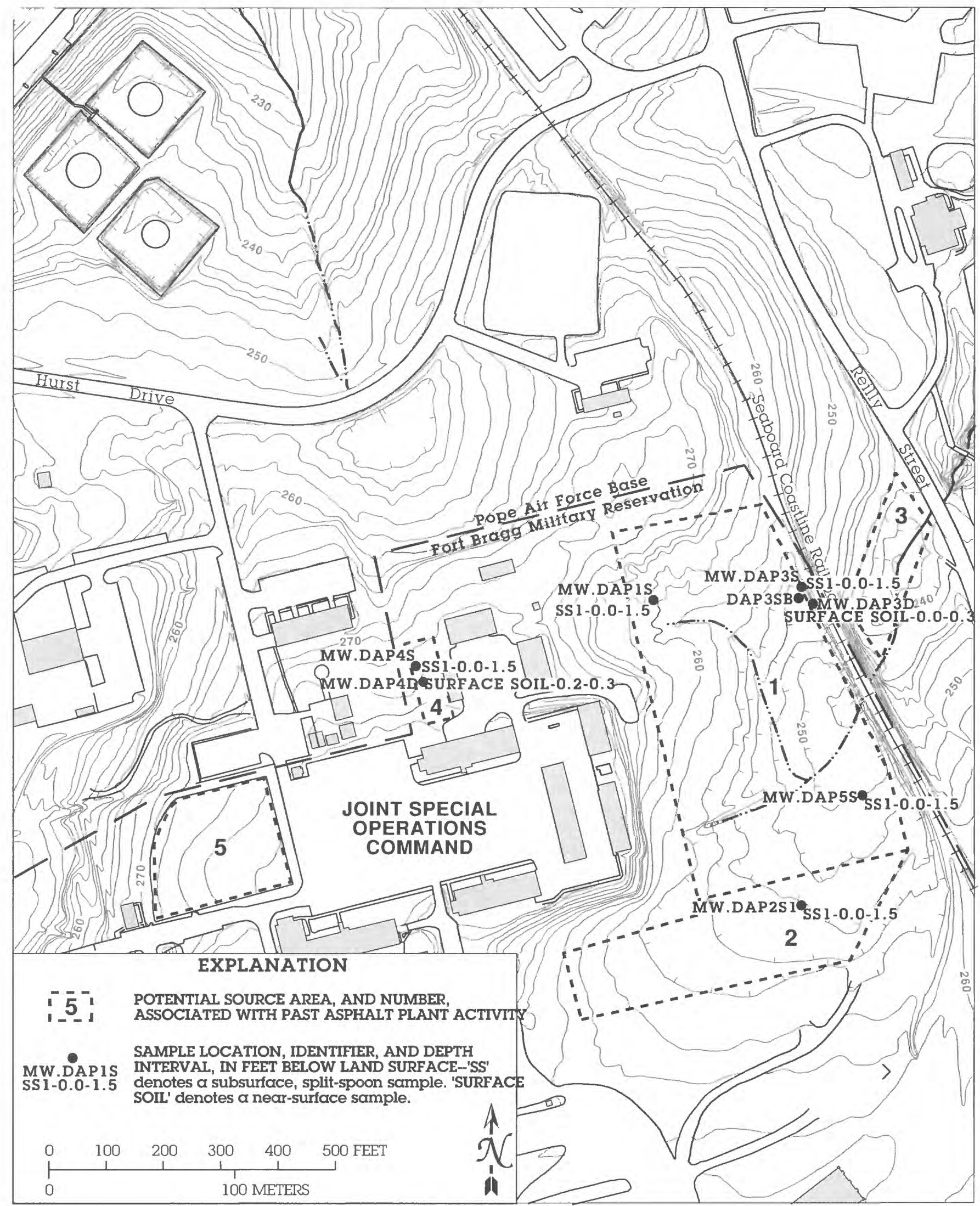

Figure 14. Near-surface soil sample locations, August 27 to November 1, 1993. 


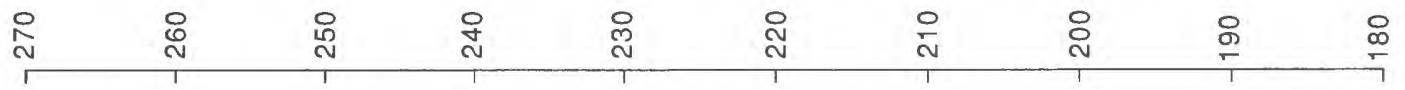
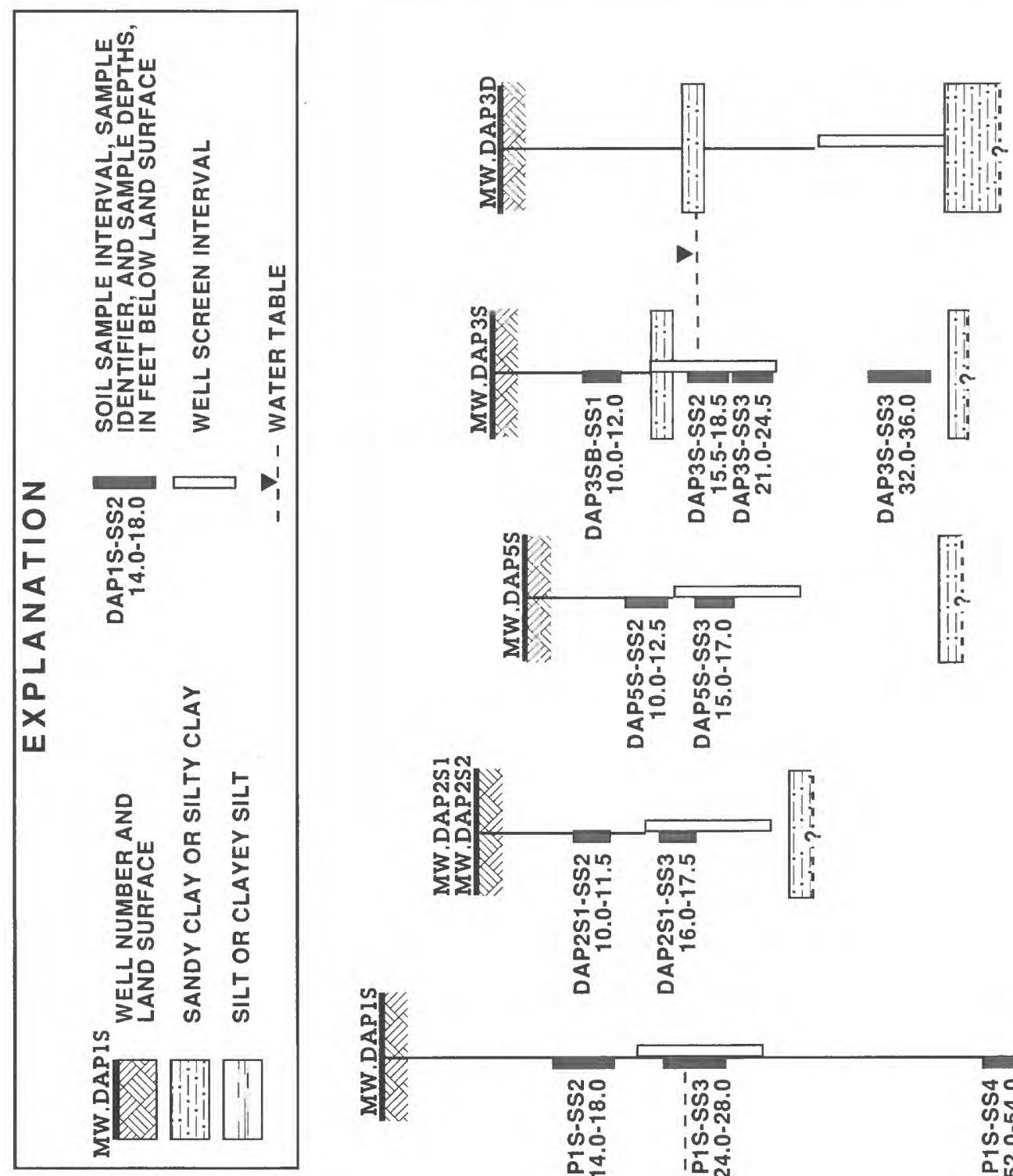

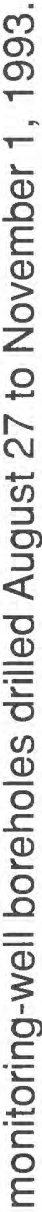
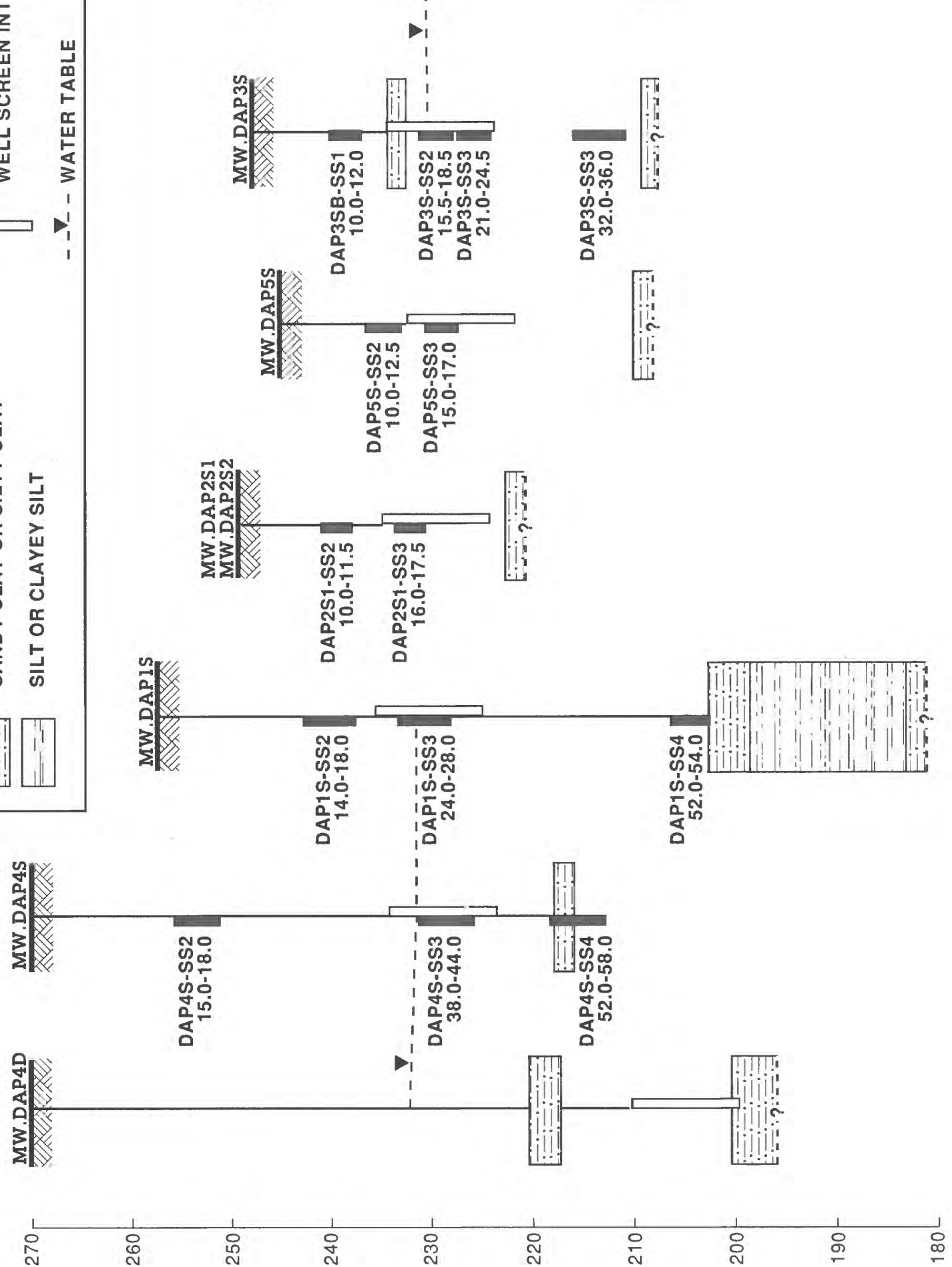

\urcorner$\exists \wedge \exists า \forall \exists S \exists \wedge O g \forall \perp \exists \exists \exists \mathrm{NI} ' \mathrm{H} \perp d \exists 0$ 
After the well was purged, a ground-water sample was collected using a 1.5-in. outsidediameter Teflon bailer. Ground water was transferred from the bailer directly to the sample container by a bottom-discharge fitting with a 0.25 -in. outside-diameter Teflon tube, approximately 6 in. long. The fitting allowed a slow and steady rate of sample flow. After sampling wells MW.DAP1S, MW.DAP2S1, MW.DAP3S, and MW.DAP3D, the bailer was decontaminated using deionized water and laboratory-grade detergent. This decontamination procedure was successful, as evidenced by the absence of cross-contamination between wells that were sampled successively. At wells MW.DAP4S, MW.DAP4D, and MW.DAP5S, the bailer was decontaminated using deionized water, laboratory-grade detergent, and isopropanol. A sample of final rinse water collected from the decontaminated bailer showed that this procedure prevented cross-contamination between wells. The Teflon bailer was used to collect all ground-water samples.

A ground-water sample was collected at each of seven wells and analyzed for the following: VOCs; semivolatile organic compounds; organochlorine pesticides and PCBs; total and dissolved metals; total cyanide; total and dissolved lead and mercury; total petroleum hydrocarbons (TPHs); total alkalinity; chloride, fluoride, sulfate, sulfite, nitrate, nitrite, and orthophosphate; $\mathrm{pH}$; total dissolved solids (TDS); specific conductance; total phosphorous, total kjeldahl nitrogen (TKN), total organic carbon (TOC); and turbidity (table 4, at end of report). Volatile organic compound samples were collected first using special care to avoid sample aeration. Three 40-milliliter (ml) glass vials were filled to just over capacity, sealed with Teflon-septa caps, and checked for bubbles. If bubbles were present, additional well water was added to the vial before the final sealing to fill airspace in the vial. Samples for other analyses were collected and preserved in glass and plastic bottles of various sizes, depending on the required analyses. Preservatives were added to the sample bottles in the laboratory before use in the field.

Samples for dissolved metals, lead, and mercury were filtered in the field at the time of collection. Samples were filtered through a 0.1 micrometer $(\mu \mathrm{m})$ membrane filter using a peristaltic pump. The filter stand, filter, and Teflon tubing were flushed thoroughly with deionized water and well water prior to sampling.

All samples were placed in iced coolers immediately upon collection. Samples were shipped to a laboratory on the day of collection, and arrived on the following day. Chain-ofcustody documentation accompanied all shipments.

Water temperature, specific conductance, and $\mathrm{pH}$ were measured for each ground-water sample. Temperature and specific conductance were measured using a factory-calibrated meter. Periodic checks were made with known standards to ensure proper calibration. A measure of $\mathrm{pH}$ was obtained for each sample using a $\mathrm{pH}$ meter that was calibrated several times each day using $\mathrm{pH}$ standards of 4.00 and 7.00 .

The following quality-control samples were collected during the sampling of ground water and surface water: an equipment-rinsate blank, a duplicate sample, a matrix-spike sample, and a matrix-spike duplicate sample. For the equipment-rinsate blank, deionized water was poured through the sampling bailer and bottom-release fitting, and was collected in sample containers. The matrix spike and matrix-spike duplicate samples were ground-water samples collected in the 
field and later spiked in the laboratory with a known chemical concentration. The matrix spike and matrix-spike duplicate samples were measured for the percentage of recovery of the spiked compound.

\section{Surface Water}

A surface-water sample was collected on March 17, 1994, from the eastern tributary (fig. 6). The sample was collected and handled using standard techniques (M.A. Sylvester, U.S. Geological Survey, written commun., 1990). Specifically, a dip-sampling method was used to collect the sample from the midpoint of a ponded section of the tributary. At the sample location, the stream was about 18 in. wide and 10 in. deep. Streamflow during sampling was too low to measure with a velocity meter. The sample was analyzed for the same constituents as those for the ground-water samples (table 4).

\section{Streambed Sediment}

One streambed-sediment sample was collected on March 18, 1994, from the eastern tributary (fig. 6). The sample was collected for chemical analyses using the core-sampling method detailed by Ward and Harr (1990). Several sub-samples were collected at various locations in the tributary and at a ground-water seep just north of the tributary. Subsamples were collected from about the top $2 \mathrm{in}$. of streambed, and were collected from the center, left, and right banks of the wetted part of the channel. The subsamples were composited into a single sample and analyzed for the following constituents: VOCs; semivolatile organic compounds; organochlorine pesticides and PCBs; total and dissolved metals; total cyanide; total and dissolved lead and mercury; TPH; total alkalinity; chloride, fluoride, sulfate, sulfite, nitrate, nitrite, and orthophosphate; $\mathrm{pH}$; TDS; specific conductance; and total phosphorous, TKN, TOC, and turbidity (table 4).

A stainless-steel spoon and bowl were used to collect the samples and were decontaminated using deionized water, laboratory-grade detergent, and isopropanol. The sediment samples were placed in iced coolers and shipped overnight to the contract laboratory for analyses.

\section{QUALITY OF SOURCE MATERIALS, SOIL, WATER, AND STREAMBED SEDIMENT}

Soil, water, and streambed-sediment samples were collected in the study area and analyzed for a number of organic and inorganic chemicals. Source materials were collected in several locations in the study area and analyzed for a number of physical and chemical properties.

\section{Source Materials}

Chemical concentrations of the DAP source materials were very low (table 5), generally well below those of the raw roofing tar (table 1) reported by Quinn and others (1985). Concentrations of semivolatile organic compounds in the source material samples were less than 4 milligram per kilogram $(\mathrm{mg} / \mathrm{kg})$, and usually were below the analytical detection limits. 
Table 5.--Summary of analytical results of source-material samples collected June 29-30, 1993

[TCLP, Toxic Characteristics Leachate Procedure; mg/L, milligrams per liter; ND, not detec ${ }^{+} \mathrm{d}$; ${ }^{\circ} \mathrm{F}$, degrees Fahrenheit; $\mu \mathrm{g} / \mathrm{kg}$, microgram per kilogram; ---, no data]

\begin{tabular}{|c|c|c|c|c|c|}
\hline $\begin{array}{l}\text { Analysis } \\
\text { (units) }\end{array}$ & Detction limits & $\begin{array}{l}\text { Source } \\
\text { area } 1\end{array}$ & $\begin{array}{l}\text { Source } \\
\text { area } 2\end{array}$ & $\begin{array}{l}\text { Source } \\
\text { area } 3\end{array}$ & $\begin{array}{c}\text { Source } \\
\text { area } 4\end{array}$ \\
\hline $\begin{array}{l}\text { TCLP Volatile organics } \\
(\mathrm{mg} / \mathrm{L})\end{array}$ & $0.025-.050$ & $\mathrm{ND}$ & $\mathrm{ND}$ & ND & $\mathrm{ND}$ \\
\hline $\begin{array}{l}\text { TCLP Semivolatile organics } \\
(\mathrm{mg} / \mathrm{L})\end{array}$ & .05-.25 & ND & $\mathrm{ND}$ & ND & $\mathrm{ND}$ \\
\hline $\begin{array}{l}\text { TCLP Chlorinated pesticides } \\
(\mathrm{mg} / \mathrm{L})\end{array}$ & $.0005-1.0$ & ND & ND & ND & ND \\
\hline $\begin{array}{l}\text { TCLP Chlorinated phenoxyacid } \\
\text { herbicides } \\
(\mathrm{mg} / \mathrm{L})\end{array}$ & .001-.005 & ND & ND & ND & ND \\
\hline TCLP Metals (mg/L) & $.002-1.0$ & & & & \\
\hline Barium & & 1.5 & 1.9 & 1.9 & 1.6 \\
\hline \multicolumn{6}{|l|}{$\begin{array}{l}\text { General inorganics-- } \\
\text { RCRA Hazardous waste } \\
\text { characterization }\end{array}$} \\
\hline Corrosivity, units & .01 & 4.7 & 5.5 & 4.8 & --- \\
\hline Ignitability, ${ }^{\circ} \mathrm{F}$ & 140 & ND & ND & ND & ND \\
\hline $\begin{array}{l}\text { Cyanide (as HCN) reactivity } \\
(\mathrm{mg} / \mathrm{kg})\end{array}$ & .50 & ND & ND & ND & ND \\
\hline $\begin{array}{l}\text { Sulfide (as } \mathrm{H} 2 \mathrm{~S}) \text { reactivity } \\
(\mathrm{mg} / \mathrm{kg})\end{array}$ & 1.25 & 3.3 & 1.8 & 1.4 & 13.6 \\
\hline \multicolumn{6}{|l|}{$\begin{array}{l}\text { Polynuclear Aromatic } \\
\text { Hydrocarbons } \\
(\mathrm{mg} / \mathrm{kg})\end{array}$} \\
\hline Fluorene & $100-300,000$ & ND & 100 & ND & ND \\
\hline Phenanthrene & $80-12,000$ & ND & 430 & 3,700 & ND \\
\hline Anthracene & $40-6,000$ & ND & ND & 360 & ND \\
\hline Fluoranthene & $100-15,000$ & ND & 180 & 2,100 & ND \\
\hline Benzo (b) fluoranthene & $100-6,000$ & ND & 130 & ND & ND \\
\hline
\end{tabular}


Results from source sampling indicate that the source-material leachate did not contain VOCs. In general, tar, pitch, and asphalt contain lower concentrations of monoaromatic compounds such as benzene, toluene, and xylenes, than polyaromatic compounds.

Few constituents were detected in the source material samples. The samples of raw source material from Area 1 and Area 4 contained one trace metal above the detection limits. Barium was detected at concentrations of 1.5 and $1.6 \mathrm{mg} / \mathrm{L}$, respectively. All other organic and inorganic chemicals were below the detection limits. Raw source material collected from Area 2 contained four PAHs. Fluorene, phenanthrene, fluoranthene, and benzo(b)-fluoranthene were detected at concentrations of 430 microgram per kilogram $(\mu \mathrm{g} / \mathrm{kg})$ or less. In addition, the trace metal barium was detected at $1.9 \mathrm{mg} / \mathrm{L}$. All other organic and inorganic chemicals, if present, were rolow the detection limits. The sample from Area 3 contained three PAHs. Phenanthrene, anthracene, and fluoranthene were detected at concentrations of $3,700 \mathrm{mg} / \mathrm{kg}$ or less. In addition, barium was detected at $1.9 \mathrm{mg} / \mathrm{L}$. All other organic and inorganic chemicals, if present, were below the detection limits.

Based on constituent concentrations in raw bitumen, it appears that natural atten tation of chemical constituents in the source material has occurred. The DAP source material, having been exposed to weathering for 30 years or more, seems to resist further breakdown achieved by the leaching action of the TCLP analytical method.

\section{Soil}

Soil-gas and soil-boring samples were collected at seven locations across the site as part of site-safety screening procedures (PSARA Technologies, Inc., 1993) (fig. 10). Soil samples from boring locations AAP-1, AAP-6, and AAP-7 were composited into a single sample, as were soil samples from boring locations AAP-2, AAP-3, AAP-4, and AAP-5. The two compositec samples were analyzed in accordance with the USEPA SW-846 methods for VOCs (metho- 8240), semivolatile organic compounds (method 3550/8270), pesticides/PCBs (method 3550/8080), and herbicides (method 8150) (U.S. Environmental Protection Agency, $1986 \mathrm{a}, \mathrm{b}, \mathrm{c}$ ). Relatively low concentrations of a small number of pesticides were detected in the composited scil-boring samples (table 6). These pesticide concentrations were attributed to routine low-level surface applications in the area (PSARA Technologies, Inc., 1993). The soil-gas samples did nct contain detectable concentrations of VOCs.

Soil samples also were collected near land surface and at selected depths in monito-ing-well boreholes. The samples were analyzed for VOCs and PAHs. The samples also were qualitatively analyzed using a library search to tentatively identify volatile compounds. A summary of analytical results for soil samples collected during the study are shown in table 7 (at tha end of report).

The sources of bitumen were expected to result in concentrations that were highest at the source and that decreased rapidly with depth. This was the case across the study area. The chemical concentrations detected in the DAP soils were limited primarily to depths at or near land surface, the depths at which the source material was believed to be located. 
Table 6.--Site-safety screening results of soil samples collected December 15-17, 1992 (from PSARA Technologies, Inc., 1993)

[ND, not detected; ppb, parts per billion]

\begin{tabular}{lccr}
\hline \multicolumn{1}{c}{ Analytes } & $\begin{array}{c}\text { Sample number } \\
\text { AAP-2,3,4,5 }\end{array}$ & AAP-1,6,7 & $\begin{array}{c}\text { Detectior } \\
\text { limit }\end{array}$ \\
\hline Volatile organics, ppb & ND & ND & $5-207$ \\
Semivolatile organics, ppb & ND & ND & $330-1,707$ \\
Pesticides/PCBs, ppb & & & \\
4,4'-DDE & ND & 21 & 2 \\
4,4'-DDT & ND & 14 & 2 \\
Endrin aldehyde & 2 & ND & 2 \\
Endrin ketone & ND & 3 & 2 \\
Endosulfan sulfate & 4 & 2 & 2 \\
Endrin & 4 & 2 & 2 \\
Methoxychlor & 27 & ND & 27 \\
Herbicides, ppb & ND & ND & $0.02-20$ \\
\hline
\end{tabular}

In general, soil samples collected at depths greater than $1 \mathrm{ft}$ did not contain detertable concentrations of VOCs and PAHs. One exception to this was the sample collected from a depth of 15.0 to $18.0 \mathrm{ft}$ in MW.DAP4S. At this location, PAHs were detected at low concentrations, with the highest being that of pyrene at $120 \mathrm{mg} / \mathrm{kg}$. Monitoring well MW.DAP4S is located about $10 \mathrm{ft}$ from the bitumen spill, and, based on GPR survey results, it appears that approximatel: two drums are buried near this location. This would explain the fact that PAHs were detected at depth. Because of their low solubility and high sorption coefficients, PAHs tend to remain sorbed on soil particles near the depths where they were deposited. The water table at this location is approximately $35 \mathrm{ft}$ bls. In all, soil samples were collected at four depths in MW.DAP4S and at one depth in MW.DAP4D (table 7). In addition, one sample was collected from soil underlying the bitumen spill. Samples collected at intervals greater than $38 \mathrm{ft}$ did not contain detertable concentrations of VOCs or PAHs, with the exception of an acetone concentration of $0.26 \mathrm{mg} / \mathrm{kg}$.

In addition to the quantitative results, the results of the qualitative library searches indicate the presence of 2-propanol in 4 of the 22 soil samples. This compound was used during equipment decontamination. In addition, dodecane was present in the soil sample collected at a depth of 10.0 to $11.5 \mathrm{ft}$ at MW.DAP2S1.

At MW.DAP1S, soil samples were collected at four depths (table 7). All VOCs were tolow detection limits, with the exception of a low concentration of acetone $(0.14 \mathrm{mg} / \mathrm{kg})$ in the ss $\mathrm{nple}$ collected from 14 to $18 \mathrm{ft}$ bls. Acetone, a common laboratory solvent, (Enseco, Incorporated, written commun., 1993) was detected in the equipment blank $(270 \mu \mathrm{g} / \mathrm{L})$ and the laboratory 
method blank sample $(0.015 \mathrm{mg} / \mathrm{kg})$. Based on their presence in blank samples and ertremely low concentrations, the acetone concentrations detected were considered to be artifacts of sampling and analysis. All PAH concentrations were below detection limits.

At MW.DAP2S1, soil samples were collected at three depths (table 7). Concentrations of VOCs were not detected in the samples, except for low concentrations of methylene chloride $(0.61 \mathrm{mg} / \mathrm{kg})$ and acetone $(4.1 \mathrm{mg} / \mathrm{kg})$ at sample depth 0.0 to $1.5 \mathrm{ft}$ bls and acetone $(1.5 \mathrm{mg} / \mathrm{kg})$ at sample depth 16.0 to $17.5 \mathrm{ft}$ bls. Methylene chloride is a common laboratory contaminant in the gas chromatographic/mass spectrometry analysis (Enseco, Incorporated, written commun., 1993), and occurred in the method blank at $3.2 \mu \mathrm{g} / \mathrm{L}$. Polynuclear aromatic hydrocarbon concentrations were not detected in the samples.

Soil samples were collected at four depths in MW.DAP3S and at one depth in the adjacent soil boring DAP3SB (table 7). In addition, one sample was collected from soil underlving the bitumen spill. Only low concentrations of acetone (maximum of $0.17 \mathrm{mg} / \mathrm{kg}$ ) were detected during VOC analyses. Several PAH concentrations were detected in the sample from th 0.0 to $1.5 \mathrm{ft}$ depth, with the highest being that of fluoranthene at $780 \mu \mathrm{g} / \mathrm{kg}$. No PAH concentrations were detected in samples taken from the other depth intervals.

At MW.DAP5S, soil samples were collected at three depths (table 7). Concentrations of VOCs were not detected in the samples. A limited number of PAHs occurred at sample c'spth 0.0 to $1.5 \mathrm{ft}$ bls. The maximum concentration detected was phenanthrene at $620 \mu \mathrm{g} / \mathrm{kg}$. No PAH concentrations were detected in samples taken from the other depth intervals.

\section{Ground Water}

Ground-water samples were collected in seven monitoring wells and analyzed for VOCs, semivolatile organic compounds, pesticides and PCBs, total and dissolved metals, and general inorganic compounds (table 8 , at end of report). In addition, these samples were analyzed using a library search to tentatively identify volatile and semivolatile organic compounds. The library search is a qualitative analysis, and, as such, chemical concentrations are considered inconclusive and are not presented. Concentrations of chemicals in the samples were compared to USEPA MCL's (table 8).

In general, ground-water samples collected at the DAP site did not contain detectable concentrations of chemicals related to past asphalt plant operations. Concentrations of volatile and semivolatile organic compounds were below detection limits with the excention of bis(2-ethylhexyl)phthalate at MW.DAP4D $(3.8 \mu \mathrm{g} / \mathrm{L})$ and MW.DAP5S $(180 \mu \mathrm{g} / \mathrm{L})$, and trichloroethane at MW.DAP4D (7.7 $\mu \mathrm{g} / \mathrm{L})$ (table 8). Bis(2-ethylhexyl)phthalate is a common laboratory artifact (Enseco, Incorporated, written commun., 1993), is almost insoluble in water, and is assumed to be associated with laboratory procedures. Trichloroethane, a chlorinated solvent, reportedly was not used in association with past DAP activities.

Qualitative library search analyses tentatively identified a small number of semivolatile organic compounds in the ground-water samples from wells MW.DAP1S, MW.DAP4S, MW.DAP4D, and MW.DAP5S. For example, 2-methyl-propanoic acid and butanoic acid were detected at MW.DAPIS; 2-butoxy-ethanol, an unknown saturated hydrocarbon $(<\mathrm{C} 10)$, and an 
oxygenated hydrocarbon were detected at MW.DAP4S; 2-butoxy-ethanol and oxygenated hydrocarbon were detected at MW.DAP4D; and 1-(2-methoxy-1-methylethoxy)-2-propano' and 2-butoxy-ethanol were detected at MW.DAP5S. Regulated MCLs currently do not exist for these compounds.

Concentrations of four compounds slightly exceeded MCLs in a small number of vrells. These compounds include trichloroethane, gamma-benzene hexachloride (BHC), heptachlor, and fluoride. In addition, several organochlorine pesticides were detected in wells MW.DAF2S2, MW.DAP3D, MW.DAP4D, and MW.DAP4S at varying concentrations below MCLs. The above compounds do not appear to be associated with the DAP.

Of the seven wells sampled, only wells MW.DAP4D and MW.DAP5S contained a detectable VOC concentration. The ground-water sample from well DAP.MW4D contaired a trichloroethane concentration of $7.7 \mathrm{mg} / \mathrm{L}$. The MCL for trichloroethane is $5 \mathrm{mg} / \mathrm{L}$. Trichloroethane is a polychlorinated aliphatic hydrocarbon used primarily as a degreaser o* dry cleaning agent. Reportedly, only non-chlorinated compounds (petroleum hydrocarbons: for example) were used as solvents at the DAP.

Trichloroethane, a known carcinogen, has a relatively high aqueous solubility $(1,360 \mathrm{mg} / \mathrm{L})$, a high specific gravity (1.46), and generally will not partition strongly into sediment organic matter. These factors cause trichloroethane to sink to the base of the aquifer. This explains why trichloroethane was detected in the deeper well of the two-well cluster in Area 4.

It appears that the source of trichloroethane is not in the immediate vicinity, because concentrations were not detected in the shallow well at this location. The sourc? of trichloroethane would likely be some unknown distance to the south because of the direction of ground-water flow in Area 4. This cannot be proven with the existing data, however. The SWMU 63 is located hydraulically upgradient about $800 \mathrm{ft}$ to the southeast. Additional rvells would be needed in Area 4 to more fully determine the depth and thickness of confining beds and the local direction of ground-water flow.

Bis(2-ethylhexyl)phthalate was detected at a concentration of $180 \mathrm{mg} / \mathrm{L}$ at well MW.DAP5S. This compound was considered a laboratory artifact and was the only semivolatile organic compound detected at this location.

Organochlorine pesticide concentrations were detected in the ground water samples from four wells. Concentrations of gamma-BHC, also known as lindane, exceeded the MCL of $0.2 \mu \mathrm{g} / \mathrm{L}$ in wells MW.DAP2S and MW.DAP4D. Combined concentrations of heptachlor and delta-BHC exceeded the MCL for heptachloride of $0.4 \mu \mathrm{g} / \mathrm{L}$ in wells MW.DAP2S2, MW.DAP4D, and MW.DAP4S. Heptachlor and delta-BHC are not separable using the selected analytical methods, and their concentrations have been quantified together. Pesticide usage was not associated with the DAP. Pesticides that were reportedly stored in nearby wooden warehc'ises (fig. 7) four decades earlier may have been spilled or disposed in the area. A more likely sc irce of pesticide concentrations is SWMU 63, a location of known pesticide storage immediately upgradient of the study area. 
In the sample from well MW.DAP2S2, seven organochlorine pesticides were detected:

alpha-BHC $(0.49 \mu \mathrm{g} / \mathrm{L})$,

beta-BHC $(0.17 \mu \mathrm{g} / \mathrm{L})$,

delta-BHC/heptachlor $(1.3 \mu \mathrm{g} / \mathrm{L})$,

4,4'-dichlorodiphenyltrichloroethane (DDT) $(0.13 \mu \mathrm{g} / \mathrm{L})$,

dieldrin $(0.51 \mu \mathrm{g} / \mathrm{L})$,

endrin $(.64 \mu \mathrm{g} / \mathrm{L})$, and

gamma-BHC $(0.47 \mu \mathrm{g} / \mathrm{L})$.

In the sample from well MW.DAP3D, two organochlorine pesticides were detected:

dieldrin at a concentration of $0.030 \mu \mathrm{g} / \mathrm{L}$, and

gamma-BHC at a concentration of $0.095 \mu \mathrm{g} / \mathrm{L}$.

In the sample from well MW.DAP4D, five organochlorine pesticides were detectec:

alpha-BHC $(0.15 \mu \mathrm{g} / \mathrm{L})$, beta-BHC $(0.09 \mu \mathrm{g} / \mathrm{L})$,

delta-BHC/heptachlor $(1.9 \mu \mathrm{g} / \mathrm{L})$,

dieldrin $(0.098 \mu \mathrm{g} / \mathrm{L})$, and

gamma-BHC $(0.76 \mu \mathrm{g} / \mathrm{L})$.

In the sample from well MW.DAP4S, three organochlorine pesticides were detecte 1 :

delta-BHC/heptachlor $(0.62 \mu \mathrm{g} / \mathrm{L})$,

dieldrin $(0.064 \mu \mathrm{g} / \mathrm{L})$, and

gamma-BHC $0.095 \mu \mathrm{g} / \mathrm{L})$.

In general, organochlorine pesticides are extremely persistent and ubiquitous environmental contaminants. However, during the last 15 to 20 years, their residue in the environment bas begun to decrease due to increased restrictions on their use and production (Smith and others 1987). Gamma-BHC was developed in 1942, heptachlor and dieldrin in 1948, and endrin in the 1950s. The approximate half-life of many organochlorine pesticides in soils is about 2 to 4 years (Metcalf, 1972).

Organochlorine pesticides are characterized by low aqueous solubilities (with the exception of gamma-BHC) and relatively high octanol-water partition coefficients and high sorption coefficients (Smith and others, 1987) (table 9). These compounds readily sorb to organic matter in sediment. As a result, pesticides typically do not deeply penetrate soils (Bouwer, 1978), and aqueous concentrations are typically in the parts per thousand range (Smith and others, 1987). Ground-water contamination by pesticides generally occurs only where the water table is close to 
the land surface or where soils are coarse-grained (Bouwer, 1978). In the study area, the depth of the water table varies from 12 to $35 \mathrm{ft}$ bls, and soils are comprised of sands intermixed with varying amounts of clay.

Other processes affect the fate of organochlorine pesticides in the environment. Pesticides are characterized by relatively low vapor pressures (Smith and others, 1987) and corresponting low mass-loss rates from solution. Despite their low vapor pressures, these compounds can be volatilized and transported atmospherically (Smith and others, 1987), particularly in surfacewater systems. Oxidation, on the other hand, is not an important factor affecting the fate of organochlorine pesticides (Smith and others, 1987). Further, many organochlorine pesticide are relatively resistant to biodegradation (Chapelle, 1993; Smith and others, 1987). Gamma-EHC, however, has been shown to biodegrade at significant rates in natural systems (Moore and Ramamoorthy, 1984). Reductive dehalogenation, as in the transformation of DDT to dichlorodiphenyldichloroethane (DDD) and then to dichlorodiphenylchloroethylene (DDE), for example, accounts for a gradual reduction of selected chlorinated pesticides in the environment.

Total and dissolved metals concentrations were generally typical of background lerels. However, ground water from well MW.DAP4D contained concentrations somewhat higher than those at other locations. Inorganic constituents commonly used as indicators of anthropogenic effects on ground-water quality include chloride, TKN, specific conductance, and TDS. Concentrations of these inorganic constituents were relatively high in some of the DAP vrells (table 8), when compared with their concentrations in rainfall. For example, based on an average of 33 rainfall samples at eight sites in western North Carolina (Laney, 1965), the reean concentrations of chloride and TDS were $0.2 \mathrm{mg} / \mathrm{L}$ and $5.1 \mathrm{mg} / \mathrm{L}$, respectively. Concentrations of chloride in the DAP ground water, in contrast, were: $749 \mathrm{mg} / \mathrm{L}$ at MW.DAP4D, $614 \mathrm{mg} / \mathrm{L}$ at MW.DAP5S, $430 \mathrm{mg} / \mathrm{L}$ at MW.DAP3D, $389 \mathrm{mg} / \mathrm{L}$ at MW.DAP2S2, and $235 \mathrm{mg} /$. at MW.DAP1S. Concentrations of TDS in DAP ground water were as follows: $1,520 \mathrm{mg} / \mathrm{L}$ at MW.DAP4D, $1,080 \mathrm{mg} / \mathrm{L}$ at MW.DAP5S, $714 \mathrm{mg} / \mathrm{L}$ at MW.DAP3D, and $491 \mathrm{mg} / \mathrm{L}$ at MW.DAP1S. Two wells contained concentrations of TKN: MW.DAP5S contained $0.7 \mathrm{mg} / \mathrm{L}$, and MW.DAP4D contained $1.6 \mathrm{mg} / \mathrm{L}$. Specific conductance was highest in wells MW.DAP4D $(2,780 \mu \mathrm{S} / \mathrm{cm})$, MW.DAP5S $(2,000 \mu \mathrm{S} / \mathrm{cm})$, MW.DAP3D $(1,400 \mu \mathrm{S} / \mathrm{cm})$, MW.DAP2S2

$(1,360 \mu \mathrm{S} / \mathrm{cm})$, and MW.DAP1S $(815 \mu \mathrm{S} / \mathrm{cm})$. As the data show, the deeper well at each of the two nested well clusters (MW.DAP3D and MW.DAP4D) contained higher concentrations of general inorganic compounds.

The fluoride concentration of $5.2 \mathrm{mg} / \mathrm{L}$ in MW.DAP4D was somewhat elevated, and exceeded the MCL of $4.0 \mathrm{mg} / \mathrm{L}$. Fluoride is a natural constituent of ground water and typically occurs at concentrations ranging from less than $0.1 \mathrm{mg} / \mathrm{L}$ to $10-20 \mathrm{mg} / \mathrm{L}$, depending on the sediments through which the ground water moves (Freeze and Cherry, 1979).

\section{Surface Water}

One surface-water sample was collected from the eastern tributary (fig. 6) and was analyzed for VOCs, semivolatile organic compounds, pesticides and PCBs, total and dissolved metals, and general inorganic compounds. In addition, a qualitative library search was used to tentatively identify volatile and semivolatile organic compounds. Results are presented in table 8 . 
Table 9.--Aqueous solubilities, octanol-water partition coefficients, and sorption coeffi:ients for selected organochlorine insecticides

[mg/L, milligrams per liter; $\mathrm{K}_{\mathrm{ow}}$, octanol-water coefficient; $\mathrm{K}_{\mathrm{om}}$, sorption coefficient normalized for organic matter; --, no data available; DDT, dichlorodiphenyltrichloro $\epsilon^{\text {thane; }}$ $\mathrm{BHC}$, benzene hexachloride]

\begin{tabular}{lllr}
\hline \multicolumn{1}{c}{ Compound } & Log $\mathrm{K}_{\mathrm{ow}}$ & $\begin{array}{c}\text { Solubility } \\
(\mathrm{mg} / \mathrm{L})\end{array}$ & $\mathrm{K}_{\mathrm{om}}$ \\
\hline 4,4' - DDT & ${ }^{1} 6.36$ & ${ }^{2} 0.0031$ & ${ }^{3} 140,000$ \\
gamma-BHC & 43.70 & ${ }^{4} 7.87$ & $5_{740}$ \\
dieldrin & -- & ${ }^{6} 0.195$ & -- \\
endrin & -- & ${ }^{6} 0.26$ & 78,300 \\
heptachlor & -- & ${ }^{6} 0.056$ & -- \\
\hline
\end{tabular}

\footnotetext{
${ }^{1}$ From Chiou and others, 1982

${ }^{2}$ From Verschueren, 1983

${ }^{3}$ From Chiou and others, 1979

${ }^{4}$ From Chiou and others, 1986

${ }^{5}$ From Chiou and others, 1985

${ }^{6}$ From Callahan and others, 1979

${ }^{7}$ From Sharom and others, 1980
}

Chemical and nutrient concentrations associated with past DAP activities generally were not detected in the surface-water sample. Only a low concentration of bis(2-ethylhexyl)phthalate $(130 \mu \mathrm{g} / \mathrm{L})$, and a qualitative identification of methyl-cyclohexane were detected. Concentrations of total and dissolved metals and general inorganics were generally at or below the concentrations detected in the ground-water samples.

\section{Streambed Sediment}

One composited streambed-sediment sample was collected along the eastern tributary and analyzed for VOCs, semivolatile organic compounds, pesticides and PCBs, metals, TCLF metals, and general inorganic compounds. In addition, a qualitative library search was used to tentatively identify volatile and semivolatile organic compounds. The sample was composited from several subsamples collected along the length of the tributary. The subsamples were collected frcm areas of the stream bottom near source material, clean sand, and organic bottom material. Results indicate the presence of relatively low concentrations of anthropogenic compounds, primarily $\mathrm{TPH}$ and pesticides (table 10). 
Volatile and semivolatile organic compounds were not detected during quantitative analyses. However, a number of semivolatile organic compounds were identified using the library search. The identified compounds are listed in table 10 . In addition, a TPH concentr tion of $113 \mathrm{mg} / \mathrm{kg}$ was detected. The TPH and semivolatile organic compounds are believed to be associated with past activities of the DAP. These compounds could have been transported ir raw bitumen that flowed through the concrete culvert underlying the railway tracks. The compounds could also have been transported in suspended sediment during storm runoff and deposited slong mildly-sloped sections of the eastern tributary. Given the relatively low solubility of most $\mathrm{cf}$ the chemicals detected in the streambed sample, it is unlikely that these chemicals were transported in ground water.

Pesticide concentrations included 4,4'-DDD at $1,400 \mathrm{mg} / \mathrm{kg}, 4,4^{\prime}-\mathrm{DDE}$ at $210 \mathrm{mg} / \mathrm{kg}$, and $4,4^{\prime}$-DDT and endosulfan sulfate at a combined concentration of $480 \mathrm{mg} / \mathrm{kg}$. Pesticide concentrations are not associated with past DAP activities.

Total and dissolved TCLP metals concentrations were typical of background concentrations. It does not appear that anthropogenic activity has affected the metals concentrations in the streambed sediment of the eastern tributary. 
Table 10.--Summary of analytical results of a streambed sample collected on March 18, 1994

[mg/kg, milligram per kilogram; mg/L, milligram per liter; ND, not detected; PCB, polychlorinated biph эnyl; DDD, dichlorodiphenyldichloroethane; DDE, dichlorodiphenylchloroethylene; DDT, dichlorodiphenyltrichloroethane; TCLP, toxicity characteristic leachate procedure]

\begin{tabular}{|c|c|}
\hline & Concentration \\
\hline Volatile organics, $\mathrm{mg} / \mathrm{kg}$ & ND \\
\hline Semivolatile organics, $\mathrm{mg} / \mathrm{kg}$ & ND \\
\hline \multicolumn{2}{|l|}{ Organochlorine pesticides, $\mathrm{PCBs}, \mathrm{mg} / \mathrm{kg}$} \\
\hline $4,4^{\prime}-$ DDD & 1,400 \\
\hline $4,4^{\prime}-\mathrm{DDE}$ & 210 \\
\hline $4,4^{\prime}-\mathrm{DDT}^{1}$ & 480 \\
\hline endosulfan sulfate ${ }^{1}$ & 480 \\
\hline Total petroleum hydrocarbons, $\mathrm{mg} / \mathrm{kg}$ & 113 \\
\hline \multicolumn{2}{|l|}{ Total metals, $\mathrm{mg} / \mathrm{kg}$} \\
\hline Aluminum & 5,860 \\
\hline Chromium & 7.9 \\
\hline Copper & 4.7 \\
\hline Iron & 4,100 \\
\hline Manganese & 12.9 \\
\hline Vanadium & 12.9 \\
\hline Zinc & 8.9 \\
\hline \multicolumn{2}{|l|}{ TCLP leachate metals, $\mathrm{mg} / \mathrm{L}$} \\
\hline Barium & .32 \\
\hline \multicolumn{2}{|l|}{ General inorganics } \\
\hline Water & 28 percent \\
\hline
\end{tabular}

${ }^{1}$ These constituents are not separable using the selected analytical method and are therefore quatified together.

Note: Library search for tentatively identified volatile and semivolatile organic compounds yielded the followi results:

Saturated hydrocarbon: $\mathrm{C} 10-\mathrm{C} 20$

Sulfur mol. (S8)

Unsaturated hydrocarbon

1-methyl-phenanthrene

Hexadecanoic acid

Oleic acid

$4,4^{\prime}-\mathrm{DDE}$

$4,4^{\prime}$ - DDD

$0, \mathrm{P}^{\prime}$ - DDE
Kelthane

Saturated hydrocarbon: $>\mathrm{C} 20$

Sterol

$1,2,3,5,6,7,8,8 \mathrm{a}$ - octahydro-naphthalene 


\section{SUMMARY}

A number of potentially hazardous chemicals were used at an asphalt plant on the Ft. Fragg Army Reservation near Fayetteville, N.C., during its operation between the early 1940's an 1 the late 1960's. Chemicals used at the site included asphalt and tar-related organic compounds such as polynuclear aromatic hydrocarbons and volatile organic compounds. Soil, water, and streambed-sediment quality in the vicinity of the DAP at Ft. Bragg, N.C., were investigated during 1992-94.

The surficial aquifer immediately underlying the DAP is comprised mainly of sands, silts, and clayey sands, with occasional interbedded clay occurring at various depths. About 12 in. of rainfall per year reportedly infiltrates to the unconfined surficial aquifer. The water table in this area is about 233 to 243 feet above sea level. Local ground water moves laterally, mainly towards the north-to-northwest at a rate of about $35 \mathrm{ft} / \mathrm{yr}$, where it is discharged to Tank Creek, Little River, or one of their tributaries. A series of clays separating the surficial aquifer from the underlying upper Cape Fear aquifer help retard vertical migration of constituents dissolved in ground water. The saprolite-bedrock aquifer lies below the upper Cape Fear aquifer.

Source-material samples did not contain volatile organic, semivolatile organic, chlorinated pesticide, nor chlorinated phenoxyacid herbicide compound concentrations above the laboratory detection limits. The samples contained low concentrations of a small number of polynuclear aromatic hydrocarbons (maximum of $3,700 \mu \mathrm{g} / \mathrm{kg}$ of phenanthrene).

In general, ground-water samples collected from the surficial aquifer did not contain detectable concentrations of chemicals related to past asphalt plant operations. Concentrations of volatile and semivolatile organic compounds were below detection limits, with the exception of low concentrations of two compounds unrelated to asphalt plant activities (kis(2ethylhexyl)phthalate at a maximum concentration of $180 \mu \mathrm{g} / \mathrm{L}$ in two wells and trichloroethene at $7.7 \mu \mathrm{g} / \mathrm{L}$ at one well). The trichloroethane concentration exceeded the USEPA MCL of $5.0 \mu \mathrm{g} / \mathrm{L}$. In addition, ground water in four wells contained concentrations of organochlorine pesticides. Of the organochlorine pesticides, concentrations of gamma-BHC (lindane) (maximum of $0.76 \mu \mathrm{g} / \mathrm{L}$ ) exceeded the USEPA MCL of $0.2 \mu \mathrm{g} / \mathrm{L}$ in two wells. One well contained a fluoride concentration of $5.2 \mathrm{mg} / \mathrm{L}$ that exceeded the USEPA MCL of $4.0 \mathrm{mg} / \mathrm{L}$. Fluoride, an inorganic compounc, is a naturally occurring constituent in ground water. Total and dissolved metals concentrations were typical of background levels.

Qualitative analyses using a library search tentatively identified a small number of semivolatile organic compounds in the ground-water samples from wells MW.DAP1S, MW.DAP4S, MW.DAP4D, and MW.DAP5S (table 9). In addition, some of the wells contained elevated levels of chloride (high of $749 \mathrm{mg} / \mathrm{L}$ ), specific conductance (high of $2,780 \mu \mathrm{S} / \mathrm{cm}$ at $25^{\circ} \mathrm{C}$ ), and total dissolved solids (high of $1,520 \mathrm{mg} / \mathrm{L}$ ).

Twelve of 22 soil samples that were collected from various depths at monitoring well locations did not contain detectable concentrations of VOCs or PAHs. The remaining ten soil samples contained very low concentrations of PAHs and (or) analytical laboratory-related volatile organic compounds. The maximum concentrations were for fluoranthene at $780 \mathrm{mg} / \mathrm{kg}$, and pyrene at $750 \mathrm{mg} / \mathrm{kg}$. In general, the PAH compounds were in sediment near land surface. 
Streambed sediment from an unnamed, eastern tributary to Tank Creek in the eastern part of the site contained a small number of semivolatile organic compounds, organochlorine pesticide compounds (a maximum of $1,400 \mathrm{mg} / \mathrm{kg}$ of $\left.4,4^{\prime}-\mathrm{DDD}\right)$, and TPH $(113 \mathrm{mg} / \mathrm{kg}$ ). Concentrations of total and dissolved TCLP metals and general inorganic compounds were typical of background concentrations. Surface water in this tributary did not contain elevated concentrations of anthropogenic chemicals. 


\section{SELECTED REFERENCES}

American Public Health Association and others, 1985, Standard methods for the examination of water and wastewater, (16th ed.): Washington, D.C., American Public Health Association, $1,268 \mathrm{p}$.

American Society for Testing Materials, 1992, Annual book of ASTM standards, v. 04.08, Soil and rock; building stones: Philadelphia, Pa., American Society for Testing Materials, $1,296 \mathrm{p}$.

Bouwer, Herman, 1978, Groundwater Hydrology, McGraw-Hill Publishing Company, p. 430.

Bouwer, Herman, and Rice, R.C., 1976, A slug test for determining hydraulic conductivit'r of unconfined aquifers with completely or partially penetrating wells: Water Resou"ces Research, v. 12, p. 423-428.

Brown, P.M., and Parker, J.M.,III, comps., 1985, Geologic map of North Carolina: Raleigh, North Carolina Department of Natural Resources and Community Development, Division of Land Resources, Geological Survey Section, scale 1:500,000.

Callahan, M.A., Slimak, M.W., Gabel, N.W., May, I.P., Fowler, C.F., Freed, J.R., Jennings, P., Durfee, R.L., Whitmore, F.C., Maestri, B., Mabey, W.R., Holt, B.R., and Gould, C., 1979, Water-Related Environmental Fate of 129 Priority Pollutants: U.S. Environmental Protection Agency, EPA-440/4-79-029a,b.

Chapelle, F.H., 1993, Ground-Water Microbiology and Geochemistry, p. 374.

Chiou, C.T., Malcolm, R.L., Brinion, T.I., and Kile, D.E., 1986, Water Solubility Enhancement of Some Organic Pollutants and Pesticides by Dissolved Humic and Fulvic Acids: Environmental Science and Technology, v. 20, no. 5, p. 502-508.

Chiou, C.T., Peters, L.J., and Freed, V.H., 1979, Physical Concept of Soil-Water Equilibria for Nonionic Organic Compounds: Science, v. 206, p. 831-832.

Chiou, C.T., Schmedding, D.W., and Manes, M., 1982, Partitioning of organic compound in octanol-water systems: Environmental Science and Technology, v. 16, no. 1, p. 4-10.

Chiou, C.T., Shoup, T.D., and Porter, P.E., 1985, Mechanistic Roles of Soil Humus and Minerals in the Sorption of Nonionic Organic Compounds from Aqueous and Organic Solutions: Organic Geochemistry, v. 8, no. 1, p. 9-14.

Conley, J.F., 1962, Geology and Mineral Resources of Moore County, North Carolina: North Carolina Department of Conservation and Development, Division of Mineral Resources, Bulletin 76, 40 p. 


\section{SELECTED REFERENCES--Continued}

Cossa, D., Picard-Berube, M., and Gouygou, J.P., 1983, Polynuclear aromatic hydrocarbons in mussels from the estuary and northwestern Gulf of St. Lawrence, Canada: Bulletin of Environmental Contamination and Toxicology, volume 31, p. 41-47.

Doull, J., Klaassen, C.D., and Amdur, M.D., 1980, Casarett and Doull's Toxicology, 2nd' edition, New York: Macmillan Publishing Company, 91 p.

Freeze, R.A. and Cherry, J.A., 1979, Groundwater, Prentice-Hall, Inc., New Jersey, p. 421-22.

Giese, G.L., Eimers, J.L., and Coble, R.W., 1991, Simulation of Ground-Water Flow in the Coastal Plain Aquifer System of North Carolina: U.S. Geological Survey Water-Resources Investigations Open-File Report 90-372, 178 p.

Gosselin, R.E., Hodge, H.C., Smith, R.P., and Gleason, M.N., 1976, Clinical Toxicology of Commercial Products, 4th edition, Baltimore: Williams and Wilkins, p. II-128.

Gosselin, R.E., Smith, R.P., and Hodge, H.C., 1984, Clinical Toxicology of Cornmercial Products, 5th edition, Baltimore: Williams and Wilkins, p. II-158.

Harrison, R.M., Perry, R., and Wellings, R.A., 1975, Polynuclear Aromatic Hydroca-bons in Raw, Potable and Waste Waters: Water Research, volume 9, p. 331-346.

Hawley, G.C., 1981, The Condensed Chemical Dictionary, 10th edition, New Yor': Van Nostrand Reinhold Company, $258 \mathrm{p}$.

Laney, R.L., 1965, A comparison of the chemical composition of rainwater and ground water in western North Carolina: U.S. Geological Survey Professional Paper, 525-C, p. C187-189.

Metcalf, R.L., 1972, Agricultural chemicals in relation to environmental quality: Insecticides today and tomorrow: Journal of Environmental Quality, v. 1, no. 1, p. 10-14.

Moore, J.W., and Ramamoorthy, S., 1984, Organic chemicals in natural waters - Applied monitoring and impact assessment: New York, Springer-Verlag, 289 p.

National Oceanic and Atmospheric Administration, 1974, Climate of the states: Water Information Center, v. 1,480 p.

North Carolina Office of Water Resources, 1980, Ground-water Resources of the Southern Pines Area, A Supplement to the Sandhills Capacity-Use Study: Raleigh, North Carolina Department of Natural Resources and Community Development, $41 \mathrm{p}$.

PSARA Technologies, Inc., 1993, Personnel Protection Evaluation, Selected Sites, Ft. Bragg, North Carolina, $60 \mathrm{p}$. 


\section{SELECTED REFERENCES--Continued}

Quinn, E.J., Wasielewski, T.N., and Conway, H.L., 1985, Assessment of Coal Tar Constituents Migration: Impacts on Soils, Ground Water, and Surface Water, presented at the Proceedings of the National Water Well Association/API Conference on Petroleum Hydrocarbons and Organic Chemicals in Ground Water - Prevention, Detection, and Restoration, November 13 to $15,1985,111-127 \mathrm{p}$.

Remedial Investigation Report, Phase 2, 1993, Volume 1, Pope Air Force Base, 182 p.

Sax, N.I., and Lewis, R.J., (eds.), 1987, Hawley's Condensed Chemical Dictionary, 11 th ed., New York: Van Nostrand Reinhold Co., 102 p.

Searle, C.E., 1976, Chemical Carcinogens, ACS Monograph 173, Washington, D.C.: American Chemical Society, $330 \mathrm{p}$.

Sharom, M.S., Miles, J.R., Harris, C.R., and McEwen, F.L., 1980, Behavior of 12 Pesticides in Soil and Aqueous Suspensions of Soil and Sediment: Water Research, v. 14, p. 1,095-1,100.

Smith, J.A., Witkowski, P.J., and Fusillo, T.V., 1987, Manmade Organic Compounds in the Surface Waters of the United States; a Review of Current Understanding: U.S. Geological Survey Open File Report 87-209, 182 p.

U.S. Environmental Protection Agency, 1983, Methods for chemical analysis of water and wastes: U.S. Environmental Protection Agency, 600-4-79-020.

U.S. Environmental Protection Agency, 1986a, Test methods for evaluating solid waste, physical/chemical methods, SW-846 (3rd ed.): U.S. Environmental Protection Agency, $1,919 \mathrm{p}$.

U.S. Environmental Protection Agency, 1986b, Methods for organic chemical analysis of municipal and industrial wastewater: Federal Register, 40 CFR 136, App. A, July 1, 1986.

U.S. Environmental Protection Agency, 1986c, Inductively Coupled Plasma-Atomic Emission Spectrometer Method for Trace Element Analyses of Water and Wastes Method 200.7: Federal Register, 40 CFR 261, App. C, July 1, 1986.

U.S. Environmental Protection Agency, 1991, Maximum contaminant levels, in U.S. Code of Federal Regulations, Title 40, Part 141, National primary drinking water regulations:

July $1,1991$.

U.S. Environmental Protection Agency, 1993a, Identification and listing of hazardous waste: Federal Register, 40 CFR 261.

U.S. Environmental Protection Agency, 1993b, Toxicity characteristics, in U.S. Code of Fed aral Regulations, Title 40, Part 261.24. 


\section{SELECTED REFERENCES--Continued}

Verschueren, Karel, 1983, Handbook of Environmental Data on Organic Chemicals (2nd ed.): New York, Van Nostrand Reinhold, 1,310 p.

Ward, J.R. and Harr, C.A., 1990, Methods for the Collection and Processing of Surfase-Water and Bed-Material Samples for Physical and Chemical Analyses: U.S. Geological Survey Open-File Report, 90-140, 71 p.

Windholz, M., ed., 1983, The Merck Index--an encyclopedia of chemicals, drugs, and biologicals: Rahway, New Jersey, Merck and Company, Inc., 1,473 p.

Winner, M.D., and Coble, R.W., 1989, Hydrogeologic framework of the North Carolina Coastal Plain aquifer system: U.S. Geological Survey Professional Paper 1404-I, 155 p. 
Table 4.--Analytical methods and detection limits for surface-soil samples and soil-boring samples collected between August 27 and November 1, 1993; water samples collected between February 25 and March 17, 1994; and streambed samples collected on March 18, 1994

[(w), water; (s), soil; $\mu \mathrm{S} / \mathrm{cm}$, microsiemens per centimeter; NA, not applicable; ${ }^{\circ} \mathrm{C}$, degrees Celsius; $\mathrm{mg} / \mathrm{L}$, milligrams per liter; $\mathrm{mg} / \mathrm{kg}$, milligrams per kilogram; $\mu \mathrm{g} / \mathrm{L}$, micrograms per liter; NR, not recovered; NS, no standard available; ICP, Inductively coupled plasma; PCB, polychlorinated biphenyl; BHC, benzene hexachloride; DDD, dichlorodiphenyldichloroethane; DDE, dichlorodiphenylchloroethylene; DDT, dichlorodiphenyltrichloroethane; TCLP, toxicity characteristic leachate procedure]

\begin{tabular}{|c|c|c|c|}
\hline \multirow{2}{*}{ Method $^{1}$} & \multirow[b]{2}{*}{ Constituent (Reporting units) } & \multicolumn{2}{|c|}{ Typical detection limits } \\
\hline & & Water & Soil \\
\hline E120.1(w) & Specific conductance $(\mu \mathrm{S} / \mathrm{cm})$ & 10.0 & NA \\
\hline E150.1(w) & $\mathrm{pH}$ (pH units) & .1 & NA \\
\hline E170.1(w) & Temperature $\left({ }^{\circ} \mathrm{C}\right)$ & .1 & NA \\
\hline \multirow[t]{5}{*}{$\mathrm{A} 403(\mathrm{w})$} & Alkalinity, field test (mg/L) & & \\
\hline & Bicarbonate alkalinity & 10 & NA \\
\hline & Carbonate alkalinity as $\mathrm{CaCO}_{3}$ & 10 & NA \\
\hline & Hydroxide alkalinity as $\mathrm{CaCO}_{3}$ & 10 & NA \\
\hline & Total alkalinity as $\mathrm{CaCO}_{3}$ & 10 & NA \\
\hline E160.1(w) & Total dissolved solids (mg/L) & 10 & NA \\
\hline \multirow[t]{6}{*}{ E300(w) } & Common anions $(\mathrm{mg} / \mathrm{L})$ & NA & NA \\
\hline & Chloride & .5 & NA \\
\hline & Fluoride & .5 & NA \\
\hline & Sulfate & 1 & NA \\
\hline & Nitrate & .05 & NA \\
\hline & Orthophosphate & .20 & NA \\
\hline SW9012(w) & Cyanide, total $(\mathrm{mg} / \mathrm{L})$ & .02 & NA \\
\hline SW9012(s) & Cyanide $(\mathrm{mg} / \mathrm{kg})$ & NA & 20 \\
\hline SW3050/6010(w) & ICP screen $(\mathrm{mg} / \mathrm{L})$ & & \\
\hline \multirow[t]{16}{*}{ SW3050/6010(s) } & ICP screen $(\mathrm{mg} / \mathrm{kg})$ & & \\
\hline & Aluminum & .2 & 20 \\
\hline & Antimony & .2 & 20 \\
\hline & Arsenic & .3 & 30 \\
\hline & Barium & .1 & 10 \\
\hline & Beryllium & .002 & .2 \\
\hline & Cadmium & .005 & 2 \\
\hline & Calcium & 5 & 500 \\
\hline & Chromium & .03 & 4 \\
\hline & Cobalt & .04 & 4 \\
\hline & Copper & .03 & 3 \\
\hline & Iron & .04 & 4 \\
\hline & Lead & .2 & 20 \\
\hline & Magnesium & 5 & 500 \\
\hline & Manganese & .01 & 1 \\
\hline & Molybdenum & 0.04 & 4 \\
\hline
\end{tabular}


Table 4.--Analytical methods and detection limits for surface-soil samples and soil-boring samples collected between August 27 and November 1, 1993; water samples collected between February 25 and March 17, 1994; and bottom-sediment samples collected on March 18, 1994--Continued

$\left[(w)\right.$, water; (s), soil; $\mu \mathrm{S} / \mathrm{cm}$, microsiemens per centimeter; NA, not applicable; ${ }^{\circ} \mathrm{C}$, degrees Celsius; $\mathrm{mg} / \mathrm{L}$, milligrams per liter; $\mathrm{mg} / \mathrm{kg}$, milligrams per kilogram; $\mu \mathrm{g} / \mathrm{L}$, micrograms per lit?r; $\mathrm{NR}$, not recovered; NS, no standard available; ICP, Inductively coupled plasma; PCB, polychlorinated biphenyl; BHC, benzene hexachloride; DDD, dichlorodiphenyldichloroethane; DDE, dichlorodiphenylchloroethylene; DDT, dichlorodiphenyltrichloroethane; TCLP, toxicity characteristic leachate procedure]

\begin{tabular}{|c|c|c|c|}
\hline \multirow{2}{*}{ Method 1} & \multirow[b]{2}{*}{ Constituent (Reporting units) } & \multicolumn{2}{|c|}{ Typical detection limits } \\
\hline & & Water & Soil \\
\hline & Nickel & 0.04 & 4 \\
\hline & Potassium & 5 & 500 \\
\hline & Selenium & .4 & 40 \\
\hline & Silver & .03 & 3 \\
\hline & Sodium & 5 & 500 \\
\hline & Thallium & 2 & 200 \\
\hline & Vanadium & .04 & 4 \\
\hline & Zinc & .01 & 1 \\
\hline SW3020/7421(w) & Lead $(\mathrm{mg} / \mathrm{L})$ & .005 & \\
\hline SW7470(w) & Mercury $(\mathrm{mg} / \mathrm{L})$ & .001 & \\
\hline SW7471(s) & Mercury (mg/kg) & NA & .5 \\
\hline SW3550/E418.1(w) & Total petroleum hydrocarbons $(\mathrm{mg} / \mathrm{L})$ & 1 & \\
\hline SW3550/E418.1(s) & Total petroleum hydrocarbons $(\mathrm{mg} / \mathrm{kg})$ & $\mathrm{NA}$ & 30 \\
\hline SW5030/8240(w) & Volatile organic compounds $(\mu \mathrm{g} / \mathrm{L})$ & & \\
\hline SW5030/8240(s) & Volatile organic compounds $(\mathrm{mg} / \mathrm{kg})$ & & \\
\hline & Acetone & 50 & .1 \\
\hline & Acrolein & 16 & .1 \\
\hline & Acrylonitrile & 10 & .1 \\
\hline & Benzene & 3 & .1 \\
\hline & Bromodichloromethane & 5 & .1 \\
\hline & Bromoform & 5 & .1 \\
\hline & Bromomethane & 10 & .1 \\
\hline & 2-Butanone & 50 & .2 \\
\hline & Carbon disulfide & 5 & .1 \\
\hline & Carbon tetrachloride & 3 & .1 \\
\hline & Chlorobenzene & 5 & .1 \\
\hline & Chlorodibromomethane & 5 & .1 \\
\hline & Chloroethane & 10 & .1 \\
\hline & 2-Chloroethyl vinyl ether & 100 & .5 \\
\hline & Chloroform & 5 & .1 \\
\hline & Chloromethane & 14 & .1 \\
\hline & Dibromomethane & 10 & .1 \\
\hline & trans-1,4-dichloro-2-butene & 50 & .1 \\
\hline
\end{tabular}


Table 4.--Analytical methods and detection limits for surface-soil samples and soil-borir, samples collected between August 27 and November 1, 1993; water samples colle :ted between February 25 and March 17, 1994; and bottom-sediment samples collected on March 18, 1994--Continued

[(w), water; (s), soil; $\mu \mathrm{S} / \mathrm{cm}$, microsiemens per centimeter; NA, not applicable; ${ }^{\circ} \mathrm{C}$, degrees Celsius; $\mathrm{mg} / \mathrm{L}$, milligrams per liter; $\mathrm{mg} / \mathrm{kg}$, milligrams per kilogram; $\mu \mathrm{g} / \mathrm{L}$, micrograms per liter; $\mathrm{NR}$, not recovered; NS, no standard available; ICP, Inductively coupled plasma; PCB, polychlorinated biphenyl; BHC, benzene hexachloride; DDD, dichlorodiphenyldichloroethane; DDE, dichlorodiphenylchloroethylene; DDT, dichlorodiphenyltrichloroethane; TCLP, toxicity characteristic leachate procedure]

\begin{tabular}{|c|c|c|c|}
\hline \multirow{2}{*}{ Method $^{1}$} & \multirow[b]{2}{*}{ Constituent (Reporting units) } & \multicolumn{2}{|c|}{ Typical detection limits } \\
\hline & & Water & Soil \\
\hline & Dichlorodifluoromethane & 10 & 0.1 \\
\hline & 1,1-Dichloroethane & 5 & .1 \\
\hline & 1,2-Dichloroethane & 3 & .1 \\
\hline & 1,1-Dichloroethene & 4 & .1 \\
\hline & trans-1,2-Dichloroethene & 5 & .1 \\
\hline & 1,2-Dichloropropane & 5 & .1 \\
\hline & cis-1,3-Dichloropropene & 5 & .1 \\
\hline & trans-1,3-Dichloropropene & 5 & .1 \\
\hline & Ethanol & 50 & .2 \\
\hline & Ethylbenzene & 5 & .1 \\
\hline & Ethyl methacrylate & 10 & .1 \\
\hline & 2-Hexanone & 50 & .1 \\
\hline & Iodomethane & 10 & .1 \\
\hline & Methylene chloride & 17 & .1 \\
\hline & 4-Methyl-2-pentanone & 50 & .1 \\
\hline & Styrene & 5 & .1 \\
\hline & 1,1,2,2-Tetrachloroethane & 7 & .1 \\
\hline & Tetrachloroethene & 3 & .1 \\
\hline & Toluene & 5 & .1 \\
\hline & 1,1,1-Trichloroethane & 5 & .1 \\
\hline & 1,1,2-Trichloroethane & 5 & .1 \\
\hline & Trichloroethene & 3 & .1 \\
\hline & Trichlorofluoromethane & 10 & .1 \\
\hline & 1,2,3-Trichloropropane & 10 & .1 \\
\hline & Vinyl acetate & 50 & .3 \\
\hline & Vinyl chloride & 11 & .1 \\
\hline & Xylenes (total) & 5 & .1 \\
\hline
\end{tabular}

SW3510/8270(w) SW3550/8270(s)
Semivolatile organic compounds $(\mu \mathrm{g} / \mathrm{L})$

Semivolatile organic compounds $(\mathrm{mg} / \mathrm{kg}$ )

Acenaphthene

Acenaphthylene

10

Acetophenone

Anthracene

4-Aminobiphenyl

Benzidine

Benzoic acid

Benzo(b)fluoranthene

$\begin{array}{rc}10 & .2 \\ 50 & 2 \\ 10 & .1 \\ 50 & 2 \\ 170 & 5 \\ 50 & 2 \\ 10 & \mathrm{NS}\end{array}$


Table 4.--Analytical methods and detection limits for surface-soil samples and soil-boring samples collected between August 27 and November 1, 1993; water samples collected between February 25 and March 17, 1994; and bottom-sediment samples colle:ted on March 18, 1994--Continued

$\left[(w)\right.$, water; (s), soil; $\mu \mathrm{S} / \mathrm{cm}$, microsiemens per centimeter; NA, not applicable; ${ }^{\circ} \mathrm{C}$, degrees Celsius; $\mathrm{mg} / \mathrm{L}$, milligrams per liter; $\mathrm{mg} / \mathrm{kg}$, milligrams per kilogram; $\mu \mathrm{g} / \mathrm{L}$, micrograms per lite $r ; \mathrm{NR}$, not recovered; NS, no standard available; ICP, Inductively coupled plasma; PCB, polychlornated biphenyl; BHC, benzene hexachloride; DDD, dichlorodiphenyldichloroethane; DDE, dichlorodiphenylchloroethylene; DDT, dichlorodiphenyltrichloroethane; TCLP, toxicity characteristic leachate procedure]

\begin{tabular}{|c|c|c|c|}
\hline \multirow{2}{*}{ Method $^{1}$} & \multirow[b]{2}{*}{ Constituent (Reporting units) } & \multicolumn{2}{|c|}{ Typical detection limits } \\
\hline & & Water & Soil \\
\hline & Benzo(k)fluoranthene & 10 & NS \\
\hline & Benzo(g,h,i)perylene & 10 & NS \\
\hline & Benzo(a)pyrene & 10 & .5 \\
\hline & Benzyl alcohol & 20 & 1 \\
\hline & bis(2-Chloroethoxy)methane & 10 & .5 \\
\hline & bis (2-Chloroethyl)ether & 10 & .5 \\
\hline & bis(2-Chloroisopropyl)ether & 10 & .5 \\
\hline & bis(2-Ethylhexyl)phthalate & 10 & .5 \\
\hline & 4-Bromophenyl phenyl ether & 10 & .5 \\
\hline & Butylbenzyl phthalate & 10 & .5 \\
\hline & 4-Chloroaniline & 20 & 1 \\
\hline & 1-Chloronaphthalene & 50 & 2.5 \\
\hline & 2-Chloronaphthalene & 10 & .5 \\
\hline & 4-Chlorophenyl phenyl ether & 10 & .5 \\
\hline & Chrysene & 10 & .5 \\
\hline & $\operatorname{Dibenz}(a, j)$ acridine & NS & NS \\
\hline & Dibenzo(a,h)anthracene & 10 & .5 \\
\hline & Dibenzofuran & 10 & .5 \\
\hline & Di-n-butylphthalate & 10 & .5 \\
\hline & 1,2-Dichlorobenzene & 5 & .5 \\
\hline & 1,3-Dichlorobenzene & 5 & .5 \\
\hline & 1,4-Dichlorobenzene & 5 & .5 \\
\hline & 3,3-Dichlorobenzidine & 30 & 1 \\
\hline & Diethyl phthalate & 20 & .5 \\
\hline & p-Dimethylaminoazobenzene & 50 & 2.5 \\
\hline & 7,12-Dimethylbenz(a)anthracene & 50 & 2.5 \\
\hline & a,a-Dimethylphenethylamine & NR & NF \\
\hline & Dimethylphthalate & 10 & .5 \\
\hline & 2,4-Dinitrotoluene & 10 & .5 \\
\hline & 2,6-Dinitrotoluene & 10 & .5 \\
\hline & Diphenylamine & 50 & 2.5 \\
\hline & 1,2-Diphenylhydrazine & 50 & 2.5 \\
\hline & Di-n-octylphthalate & 10 & .5 \\
\hline & Ethyl methanesulfonate & 50 & 2.5 \\
\hline & Fluoranthene & 10 & .5 \\
\hline & Fluorene & 10 & .5 \\
\hline & Hexachlorobenzene & 10 & .5 \\
\hline & Hexachlorobutadiene & 10 & .5 \\
\hline
\end{tabular}


Table 4.--Analytical methods and detection limits for surface-soil samples and soil-boring samples collected between August 27 and November 1, 1993; water samples collested between February 25 and March 17, 1994; and bottom-sediment samples collected on March 18, 1994--Continued

[(w), water; (s), soil; $\mu \mathrm{S} / \mathrm{cm}$, microsiemens per centimeter; NA, not applicable; ${ }^{\circ} \mathrm{C}$, degrees Celsius; $\mathrm{mg} / \mathrm{L}$, milligrams per liter; $\mathrm{mg} / \mathrm{kg}$, milligrams per kilogram; $\mu \mathrm{g} / \mathrm{L}$, micrograms per liter; $\mathrm{NR}$, not recovered; NS, no standard available; ICP, Inductively coupled plasma; PCB, polychlorinated biphenyl; BHC, benzene hexachloride; DDD, dichlorodiphenyldichloroethane; DDE, dichlorodiphenylchloroethylene; DDT, dichlorodiphenyltrichloroethane; TCLP, toxicity characteristic leachate procedure]

\begin{tabular}{|c|c|c|c|}
\hline \multirow{2}{*}{ Method $^{1}$} & \multirow[b]{2}{*}{ Constituent (Reporting units) } & \multicolumn{2}{|c|}{ Typical detection limits } \\
\hline & & Water & Soil \\
\hline & Hexachlorocyclopentadiene & 10 & 0.5 \\
\hline & Hexachloroethane & 10 & .5 \\
\hline & Indeno( $(1,2,3-\mathrm{c}, \mathrm{d})$ pyrene & 10 & .5 \\
\hline & Isophorone & 10 & .5 \\
\hline & 3-Methylcholanthrene & 50 & 2.5 \\
\hline & Methyl methanesulfonate & 50 & 2.5 \\
\hline & 2-Methylnaphthalene & 10 & .5 \\
\hline & Naphthalene & 10 & 0.5 \\
\hline & 1-Naphthylamine & 50 & 2.5 \\
\hline & 2-Naphthylamine & 50 & 2.5 \\
\hline & 2-Nitroaniline & 50 & 2.5 \\
\hline & 3-Nitroaniline & 50 & 2.5 \\
\hline & 4-Nitroaniline & 58 & 2.5 \\
\hline & Nitrobenzene & 10 & .5 \\
\hline & n-Nitroso-di-n-butylamine & 50 & 2.5 \\
\hline & n-Nitrosodimethylamine & 50 & 2.5 \\
\hline & n-Nitrosodiphenylamine & 10 & .5 \\
\hline & n-Nitrosodipropylamine & 10 & .5 \\
\hline & n-Nitrosopiperidine & 50 & 2.5 \\
\hline & Pentachlorobenzene & 50 & 2.5 \\
\hline & Pentachloronitrobenzene & 50 & 2.5 \\
\hline & Phenacetin & 50 & 2.5 \\
\hline & Phenanthrene & 10 & .5 \\
\hline & 2-Picoline & 50 & 2.5 \\
\hline & Pronamide & 50 & 2.5 \\
\hline & Pyrene & 10 & 2.5 \\
\hline & 1,2,4,5-Tetrachlorobenzene & 50 & 2.5 \\
\hline & 1,2,4-Trichlorobenzene & 10 & .5 \\
\hline & 4-Chloro-3-methylphenol & 10 & .5 \\
\hline & 2-Chlorophenol & 10 & .5 \\
\hline & 2,4-Dichlorophenol & 10 & .5 \\
\hline & 2,6-Dichlorophenol & 50 & 2.5 \\
\hline & 2,4-Dimethylphenol & 10 & .5 \\
\hline & 4,6-Dinitro-2-methylphenol & 50 & 1.5 \\
\hline & 2,4-Dinitrophenol & 50 & 1.5 \\
\hline & 2-Methylphenol & 10 & .5 \\
\hline & 4-Methylphenol & 10 & .5 \\
\hline
\end{tabular}


Table 4.--Analytical methods and detection limits for surface-soil samples and soil-boring samples collected between August 27 and November 1, 1993; water samples cc!lected between February 25 and March 17, 1994; and bottom-sediment samples collected on March 18, 1994--Continued

[(w), water; (s), soil; $\mu \mathrm{S} / \mathrm{cm}$, microsiemens per centimeter; NA, not applicable; ${ }^{\circ} \mathrm{C}$, degrees Celsius; $\mathrm{mg} / \mathrm{L}$, milligrams per liter; $\mathrm{mg} / \mathrm{kg}$, milligrams per kilogram; $\mu \mathrm{g} / \mathrm{L}$, micrograms per liter; $\mathrm{NR}$, not recovered; NS, no standard available; ICP, Inductively coupled plasma; $P C B$, polychlorinated biphenyl; BHC, benzene hexachloride; DDD, dichlorodiphenyldichloroethane; DDE, dichlorodiphenylchloroethylene; DDT, dichlorodiphenyltrichloroethane; TCLP, toxicity characteristic leachate procedure]

\begin{tabular}{llcc}
\hline Method $^{1}$ & \multicolumn{2}{c}{ Typical detection limits } \\
& Constituent (Reporting units) & Water & Soil \\
\hline & & 10 & 0.5 \\
2-Nitrophenol & 50 & 2.5 \\
4-Nitrophenol & 30 & 1.5 \\
Pentachlorophenol & 10 & .5 \\
Phenol & 50 & 2.5 \\
2,3,4,6-Tetrachlorophenol & 50 & 1.5 \\
2,4,5-Trichlorophenol & 10 & .5
\end{tabular}

SW3510/8080(w) SW3550/8080(s)
Organochlorine pesticides and PCB's $(\mu \mathrm{g} / \mathrm{L})$

Organochlorine pesticides and PCB's $(\mathrm{mg} / \mathrm{kg})$

$\begin{array}{lll}\text { Aldrin } & .05 & .01 \\ \text { alpha-BHC } & .05 & .01 \\ \text { beta-BHC } & .05 & .01 \\ \text { delta-BHC } & .05 & .01 \\ \text { gamma-BHC (Lindane) } & .05 & .01 \\ \text { Chlordane } & .05 & .10 \\ 4,4 \text { '-DDD } & .1 & .02 \\ 4,4 \text { '-DDE } & .1 & .02 \\ 4,4 \text { '-DDT } & .1 & .02 \\ \text { Dieldrin } & .02 & .02 \\ \text { Endrin } & .06 & .02 \\ \text { Endrin aldehyde } & .1 & .02 \\ \text { Endosulfan I } & .05 & .01 \\ \text { Endosulfan II } & .1 & .02 \\ \text { Endosulfan sulfate } & .1 & .02 \\ \text { Heptachlor } & .02 & .01 \\ \text { Heptachlor epoxide } & .05 & .01 \\ \text { Methoxychlor } & .5 & .10 \\ \text { Toxaphene } & 1.0 & .20 \\ \text { PCB-1016 } & .5 & .10 \\ \text { PCB-1221 } & .5 & .10 \\ \text { PCB-1232 } & .5 & .10 \\ \text { PCB-1242 } & .5 & .10 \\ \text { PCB-1248 } & .5 & .10 \\ \text { PCB-1254 } & 1.0 & .20 \\ \text { PCB-1260 } & 1.0 & .20\end{array}$


Table 4.--Analytical methods and detection limits for surface-soil samples and soil-borir 7 samples collected between August 27 and November 1, 1993; water samples collested between February 25 and March 17, 1994; and bottom-sediment samples collected on March 18, 1994--Continued

[(w), water; (s), soil; $\mu \mathrm{S} / \mathrm{cm}$, microsiemens per centimeter; $\mathrm{NA}$, not applicable; ${ }^{\circ} \mathrm{C}$, degrees Celsius; $\mathrm{mg} / \mathrm{L}$, milligrams per liter; $\mathrm{mg} / \mathrm{kg}$, milligrams per kilogram; $\mu \mathrm{g} / \mathrm{L}$, micrograms per liter; $\mathrm{P}$ 'R, not recovered; NS, no standard available; ICP, Inductively coupled plasma; PCB, polychlorinated biphenyl; BHC, benzene hexachloride; DDD, dichlorodiphenyldichloroethane; DDE, dichlorodiphenylchloroethylene; DDT, dichlorodiphenyltrichloroethane; TCLP, toxicity characteristic leachate procedure]

\begin{tabular}{|c|c|c|c|}
\hline \multirow[b]{2}{*}{ Method ${ }^{1}$} & \multirow[b]{2}{*}{ Constituent (Reporting units) } & \multicolumn{2}{|c|}{ Typical detection limits } \\
\hline & & Water & Soil \\
\hline \multirow[t]{10}{*}{ SW1311(s) } & $\begin{array}{l}\text { Toxicity characteristics (mg/L in leachate) } \\
\text { leaching procedure (TCLP) }\end{array}$ & & \\
\hline & Metals & & \\
\hline & Arsenic & NA & 0.50 \\
\hline & Barium & NA & 5 \\
\hline & Cadmium & NA & .05 \\
\hline & Chromium & NA & .50 \\
\hline & Lead & NA & .50 \\
\hline & Mercury & NA & .02 \\
\hline & Selenium & NA & .05 \\
\hline & Silver & NA & .50 \\
\hline D2216(s) & Soil moisture (percent) & NA & .10 \\
\hline
\end{tabular}

${ }^{1}$ Method numbers preceded by A are from American Public Health Association and others, 1985; method numbers preceded by E are from U.S. Environmental Protection Agency (1983), U.S. Environmental Protection Agency (1986b), and U.S. Environmental Protection Aigency (1986c); method numbers preceded by D are from American Society for Testing Materials, 1992; and method numbers preceded by SW are from U.S. Environmental Protection Agency, 1986a. 


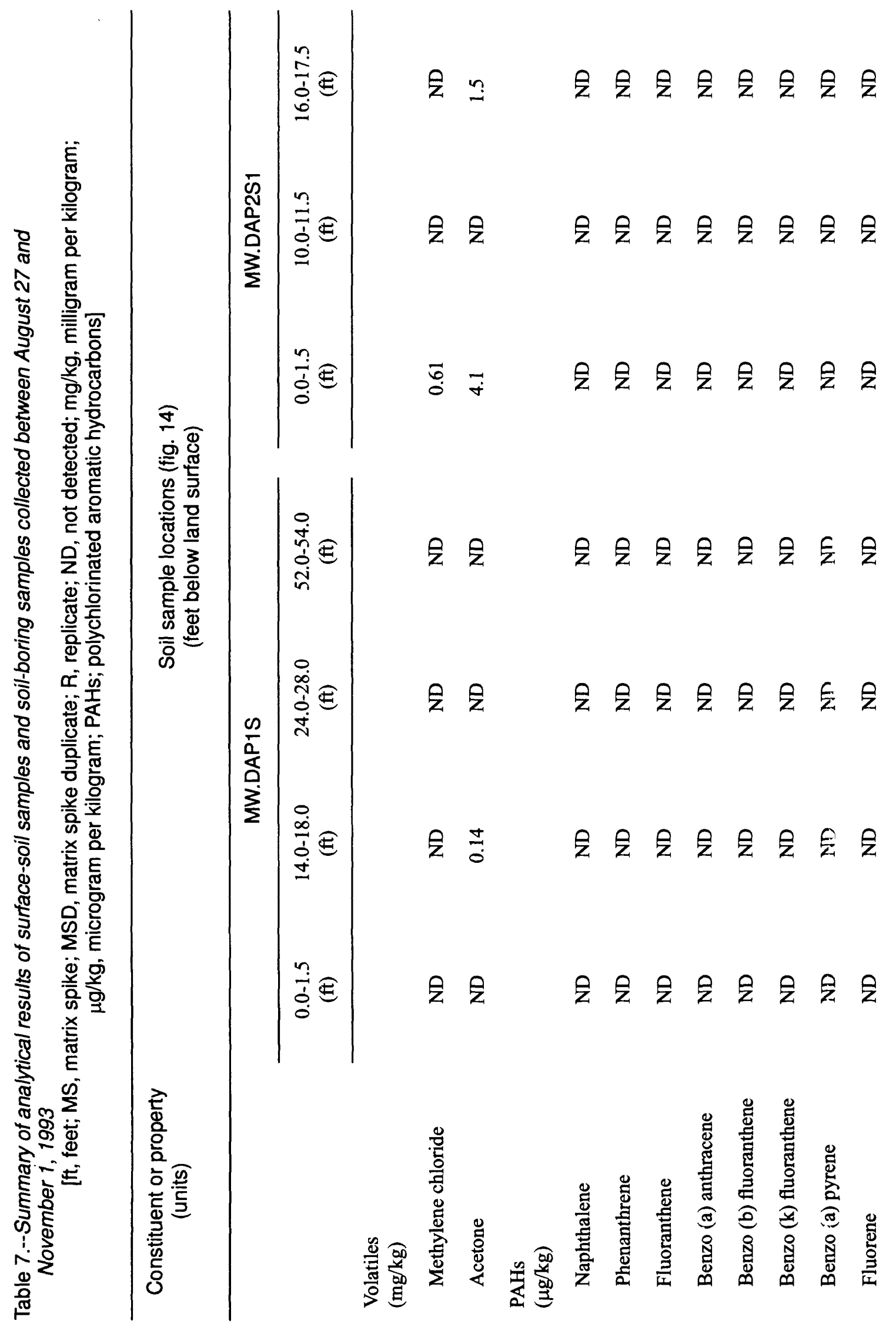

62 


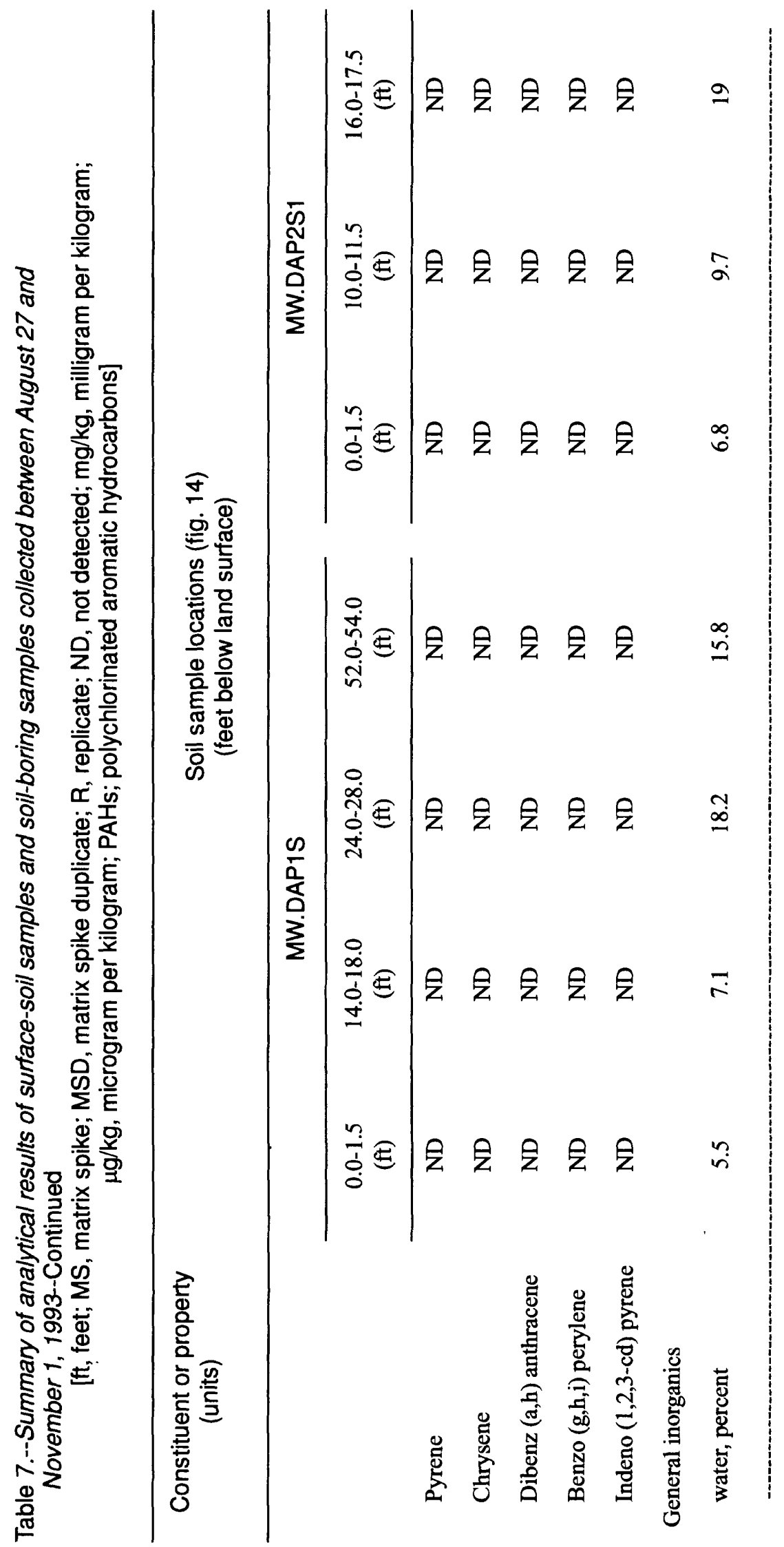




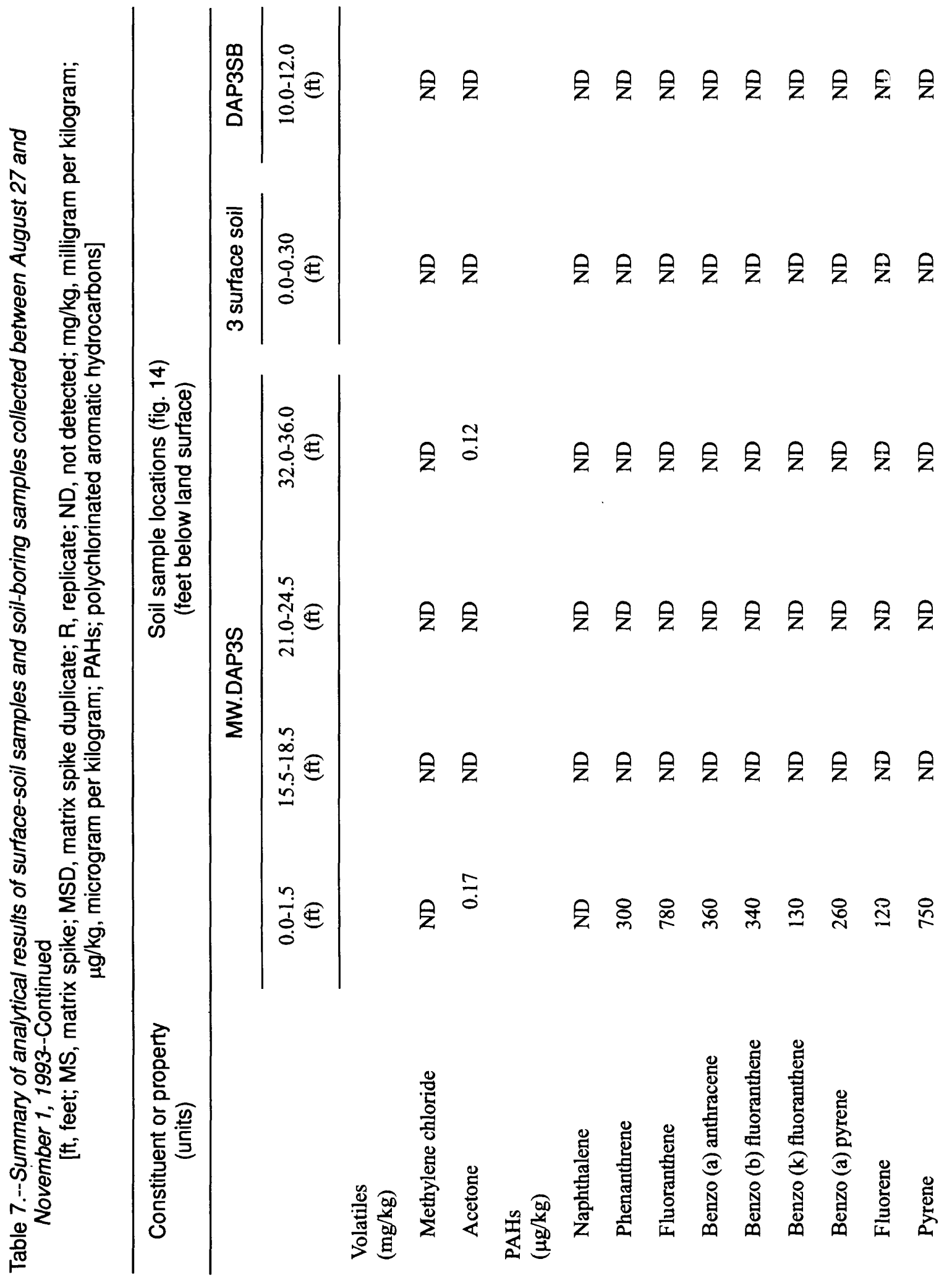




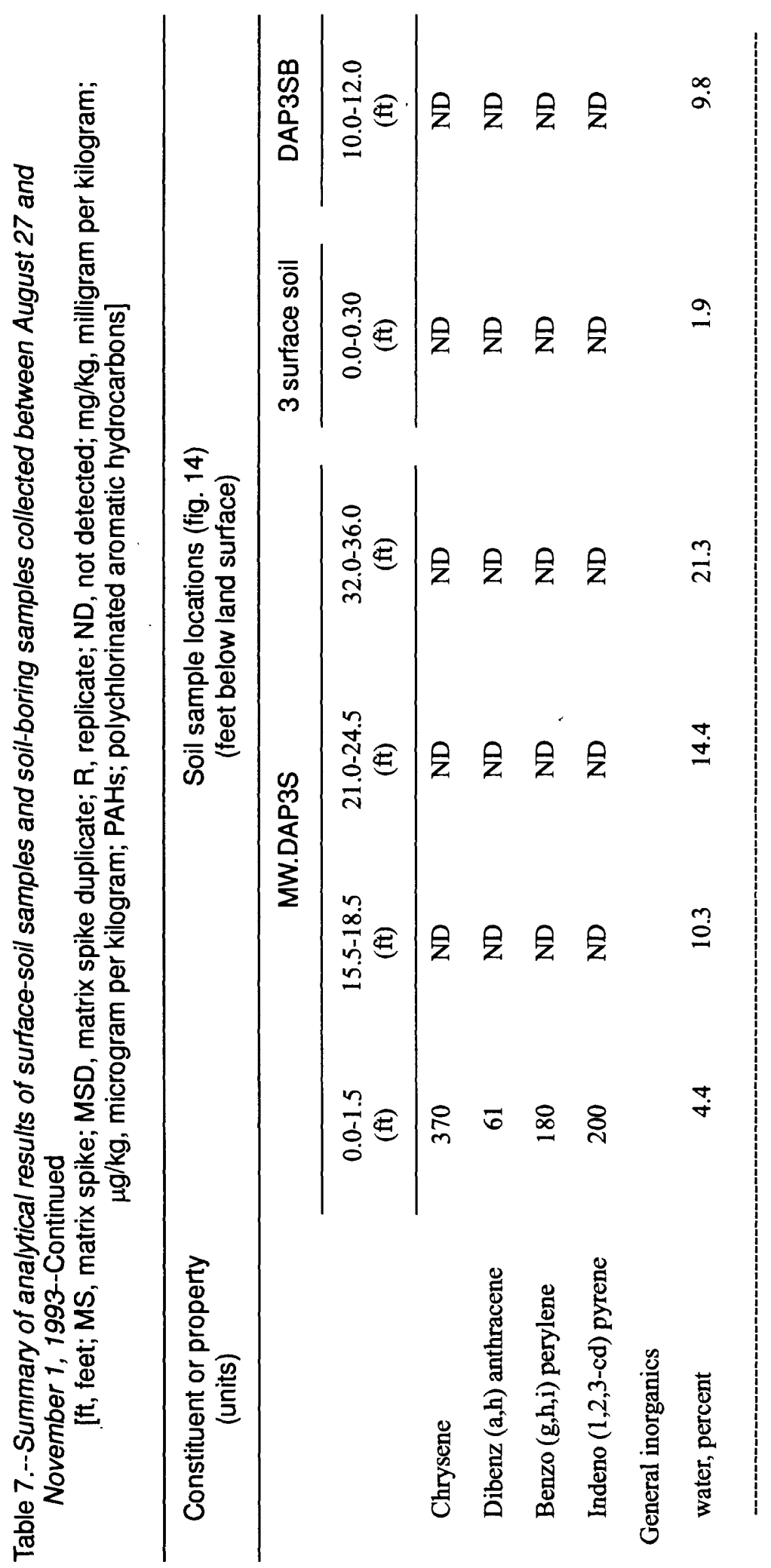




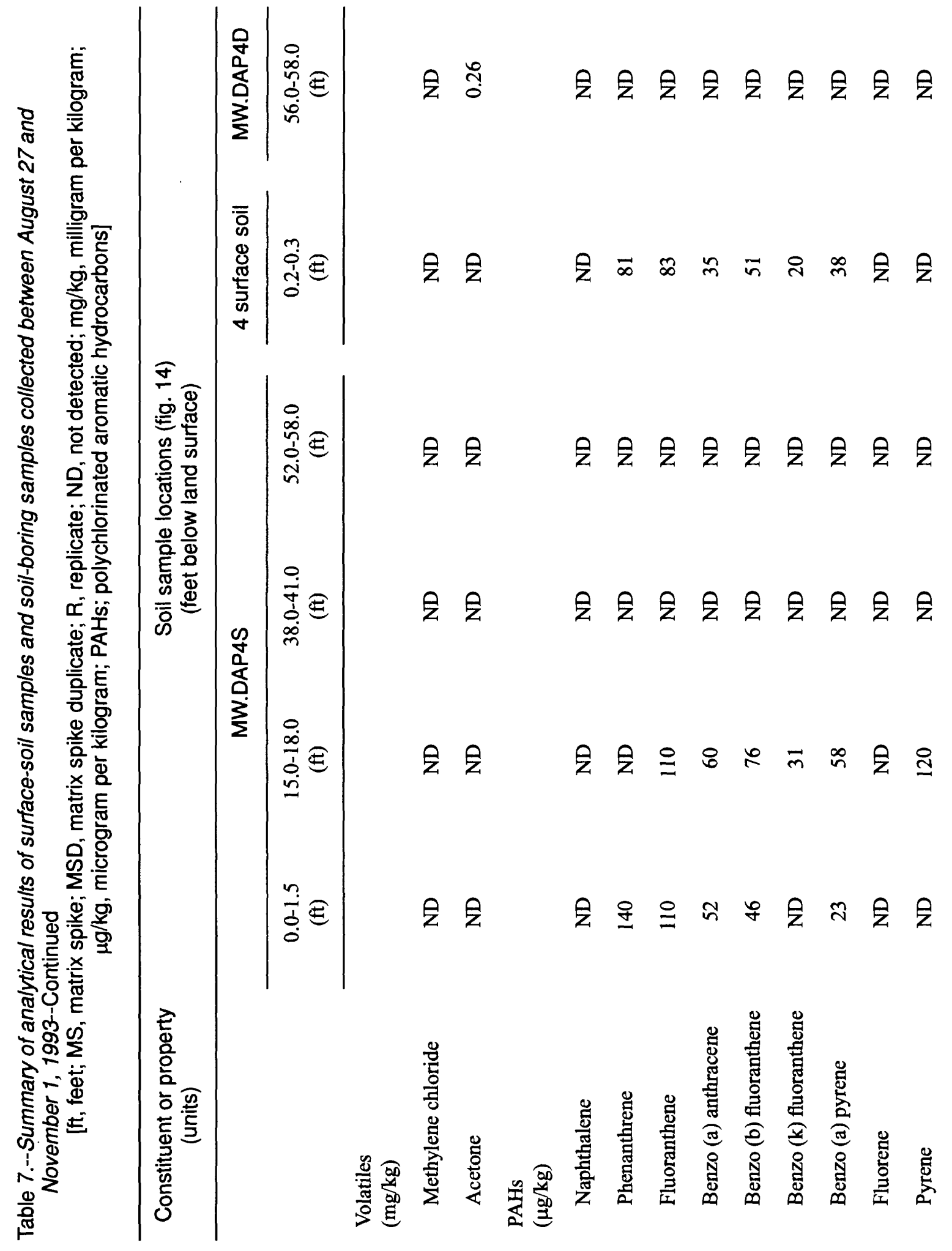




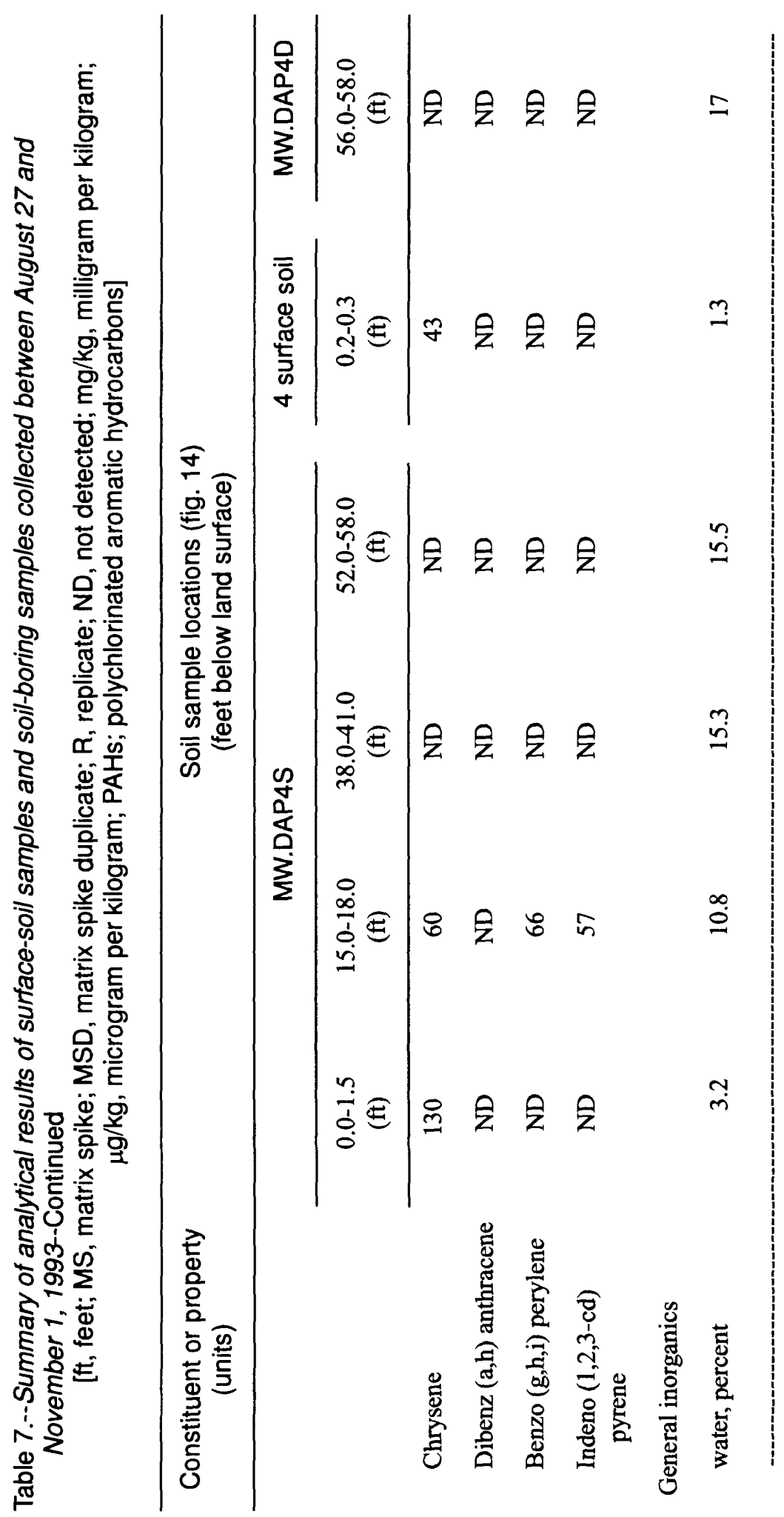




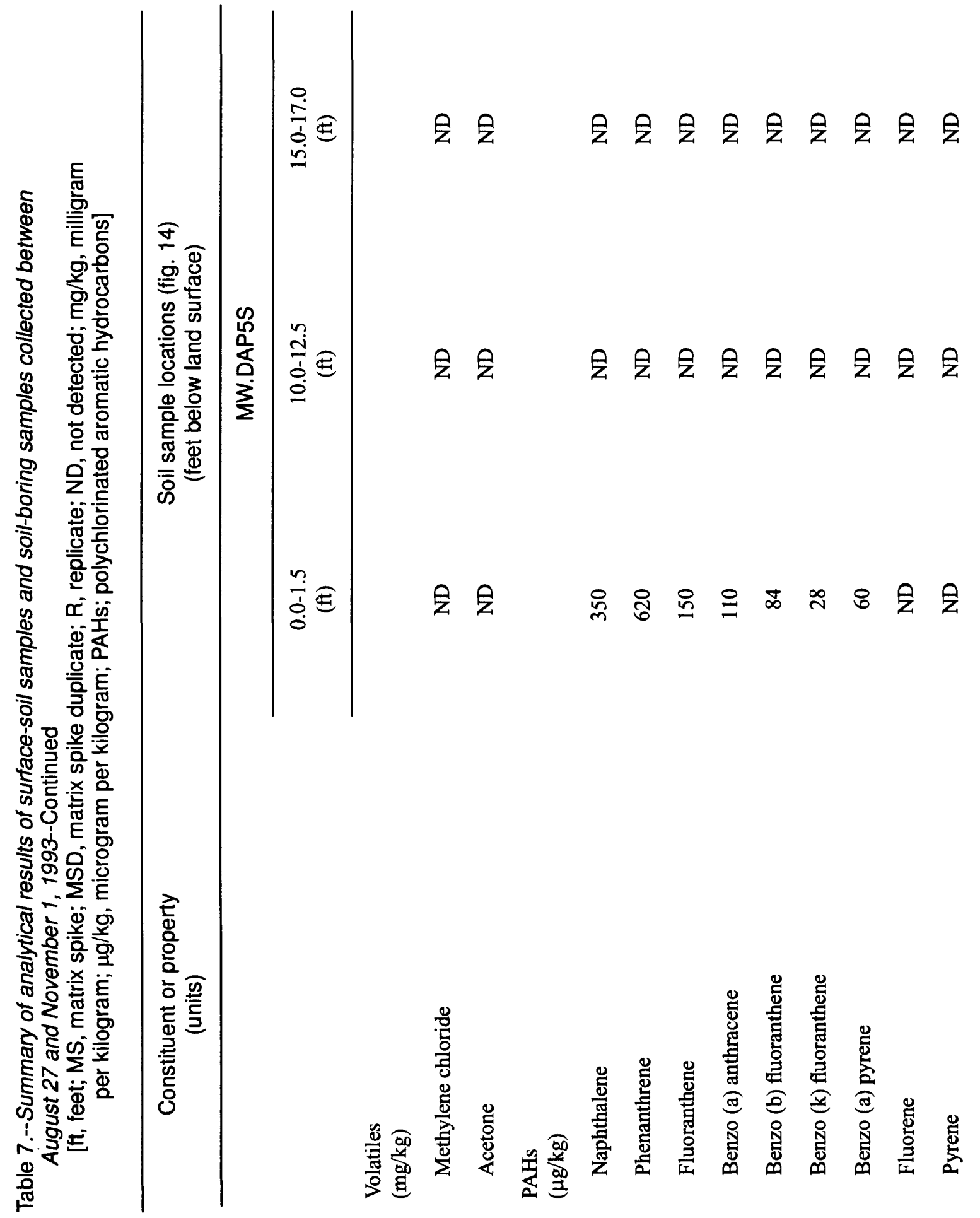




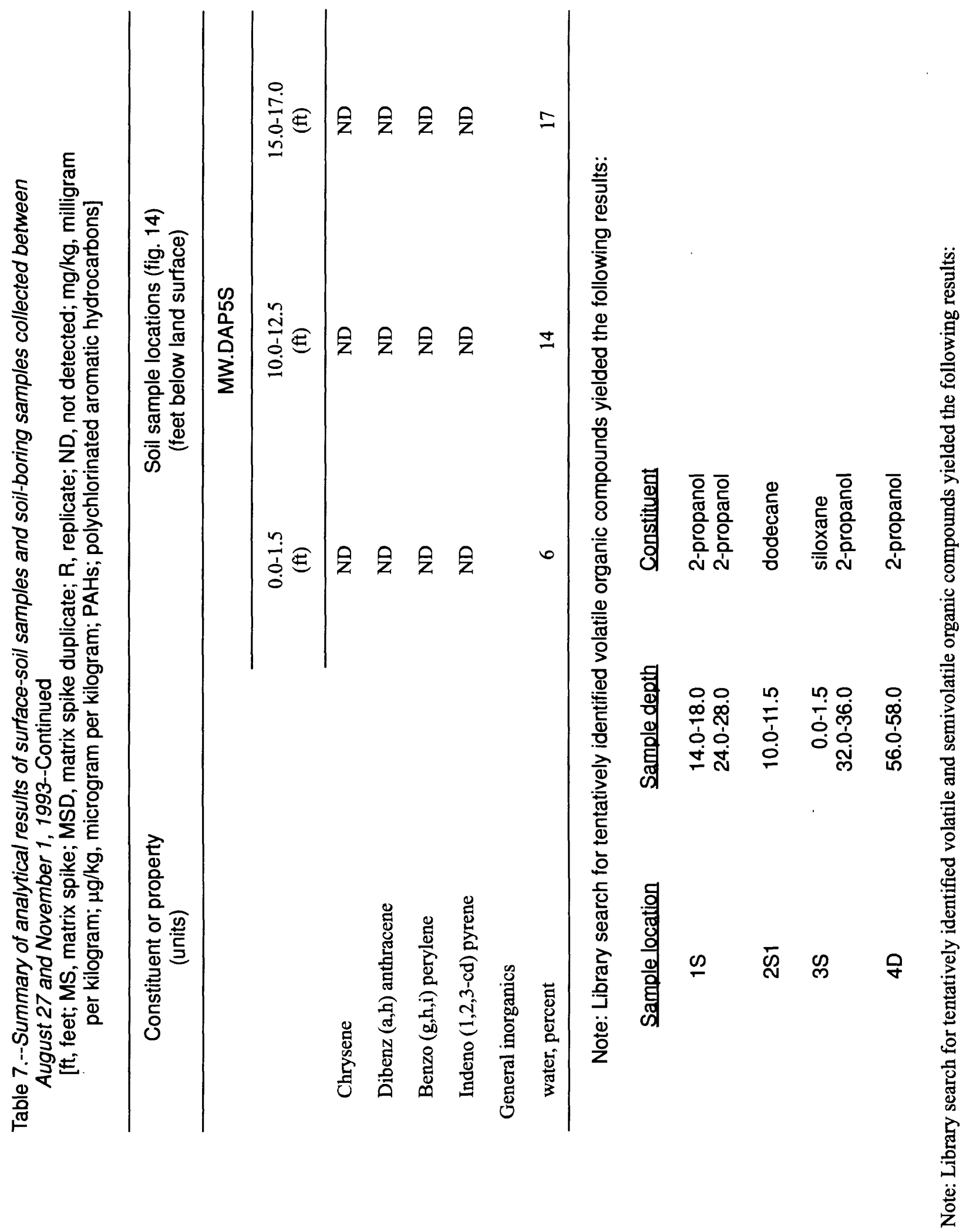




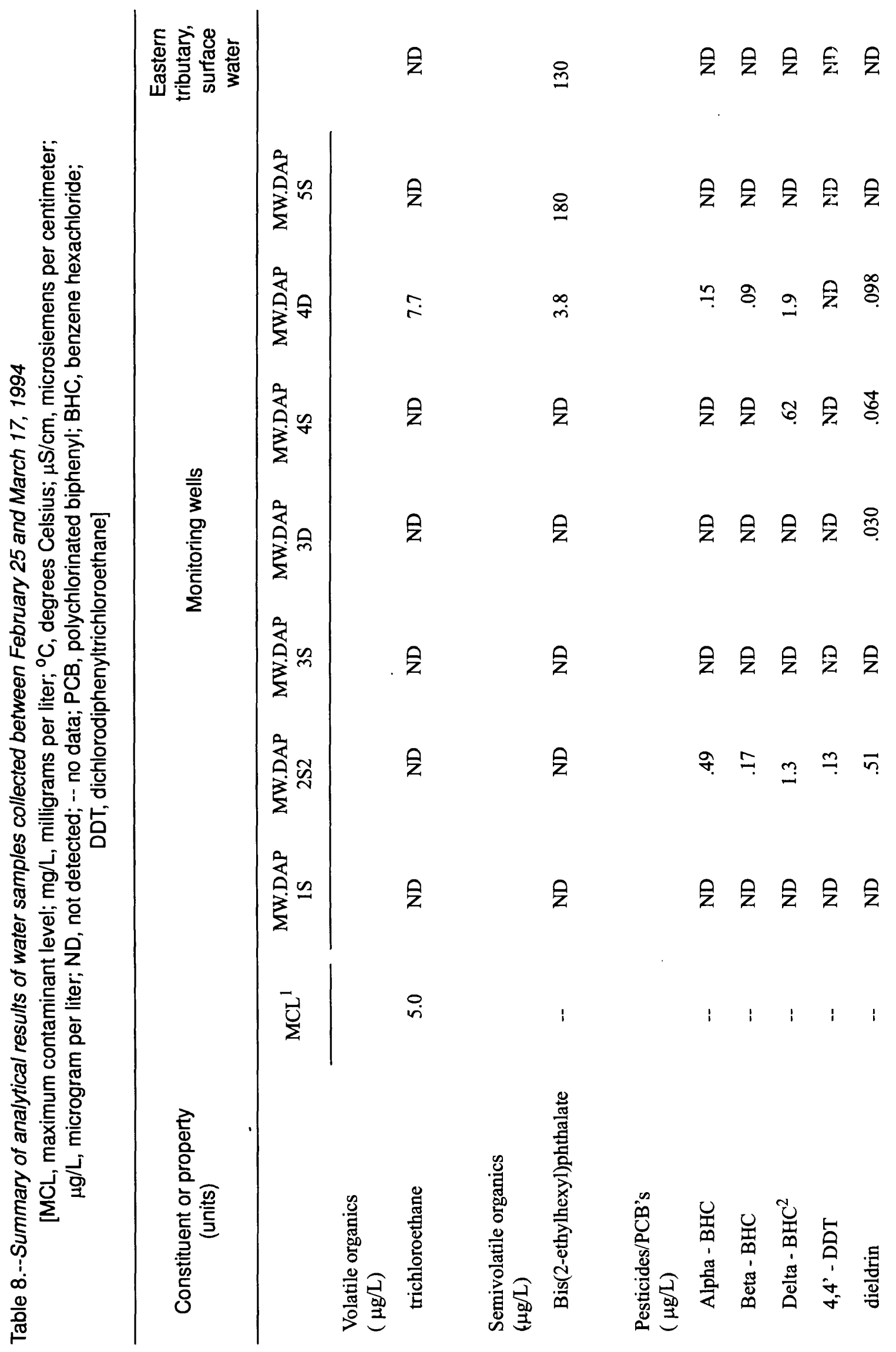




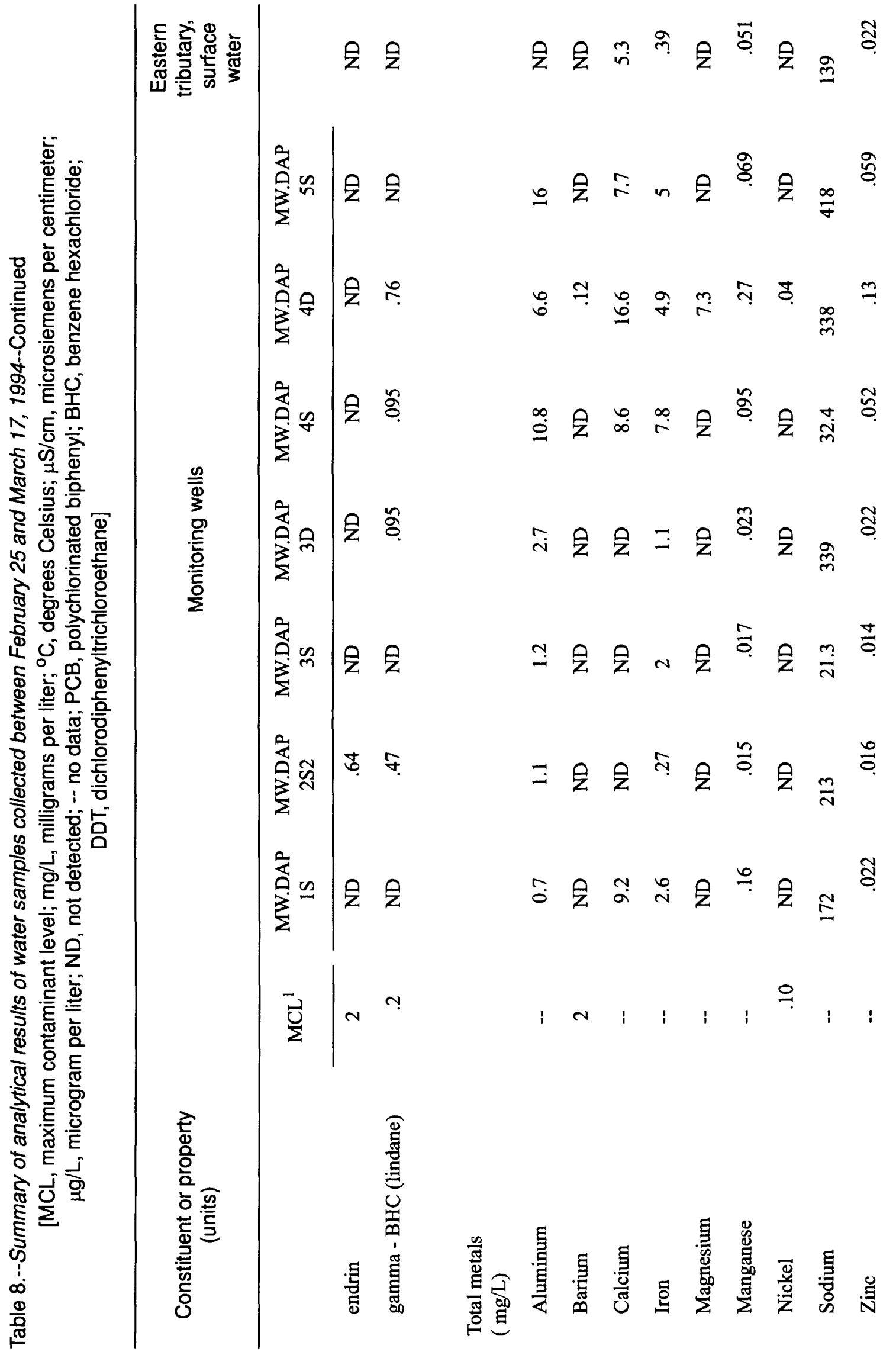




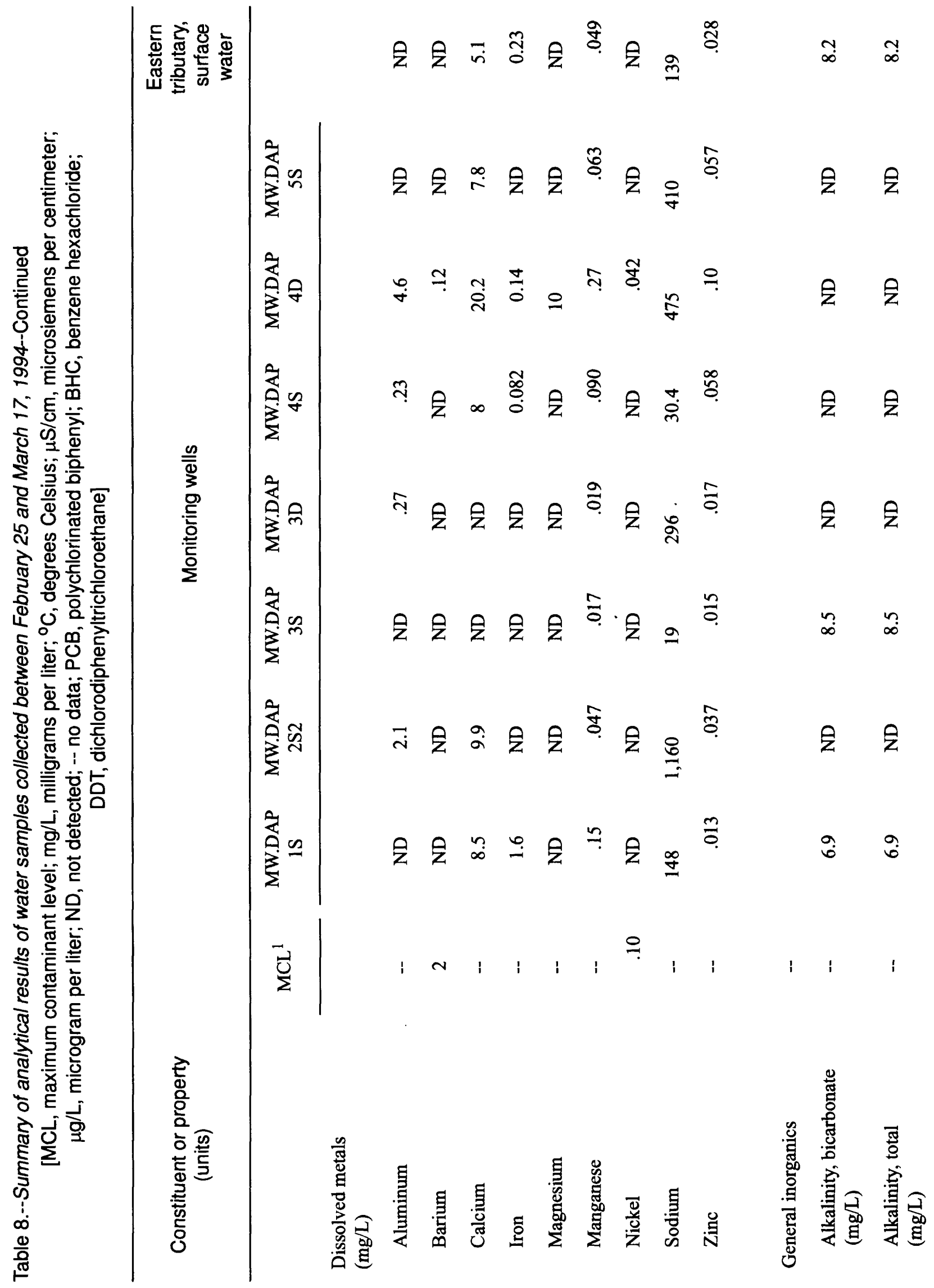




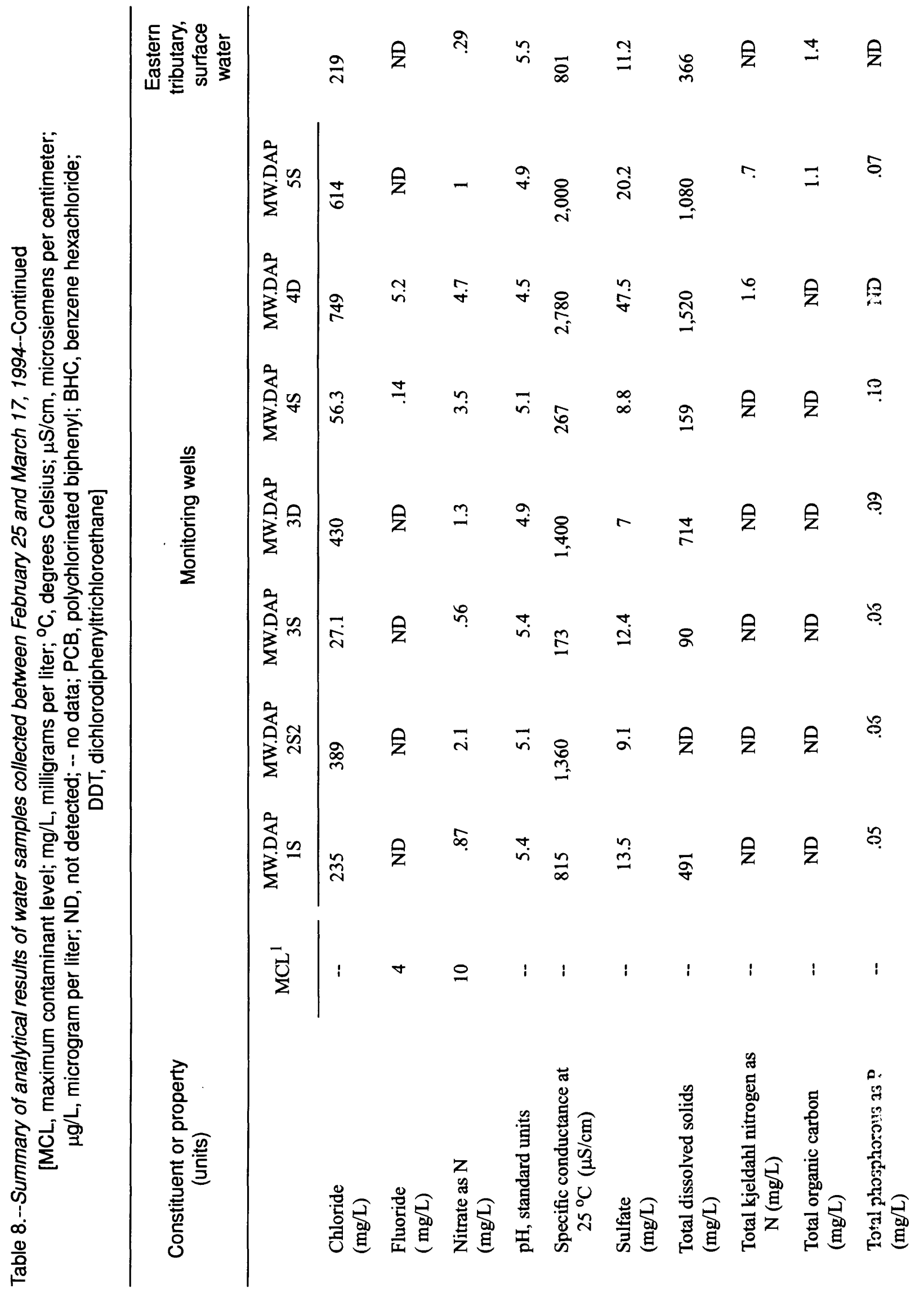




\section{APPENDIX 1}

Gamma logs from site BS1 and selected wells installed during this investigation 


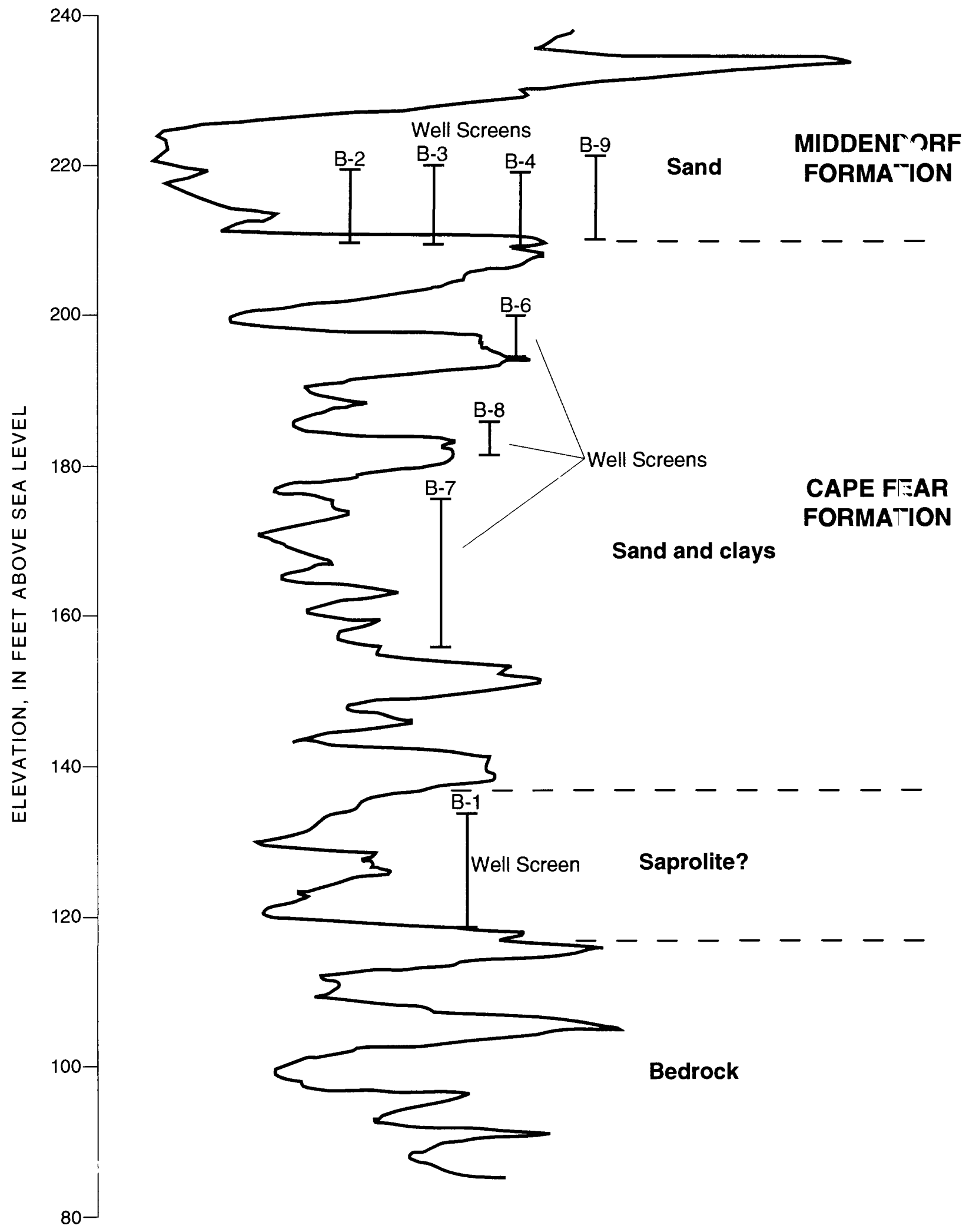

Placement of well screens in relation to the hydrogeologic framework and natural gamma-ray log, site BS1. 

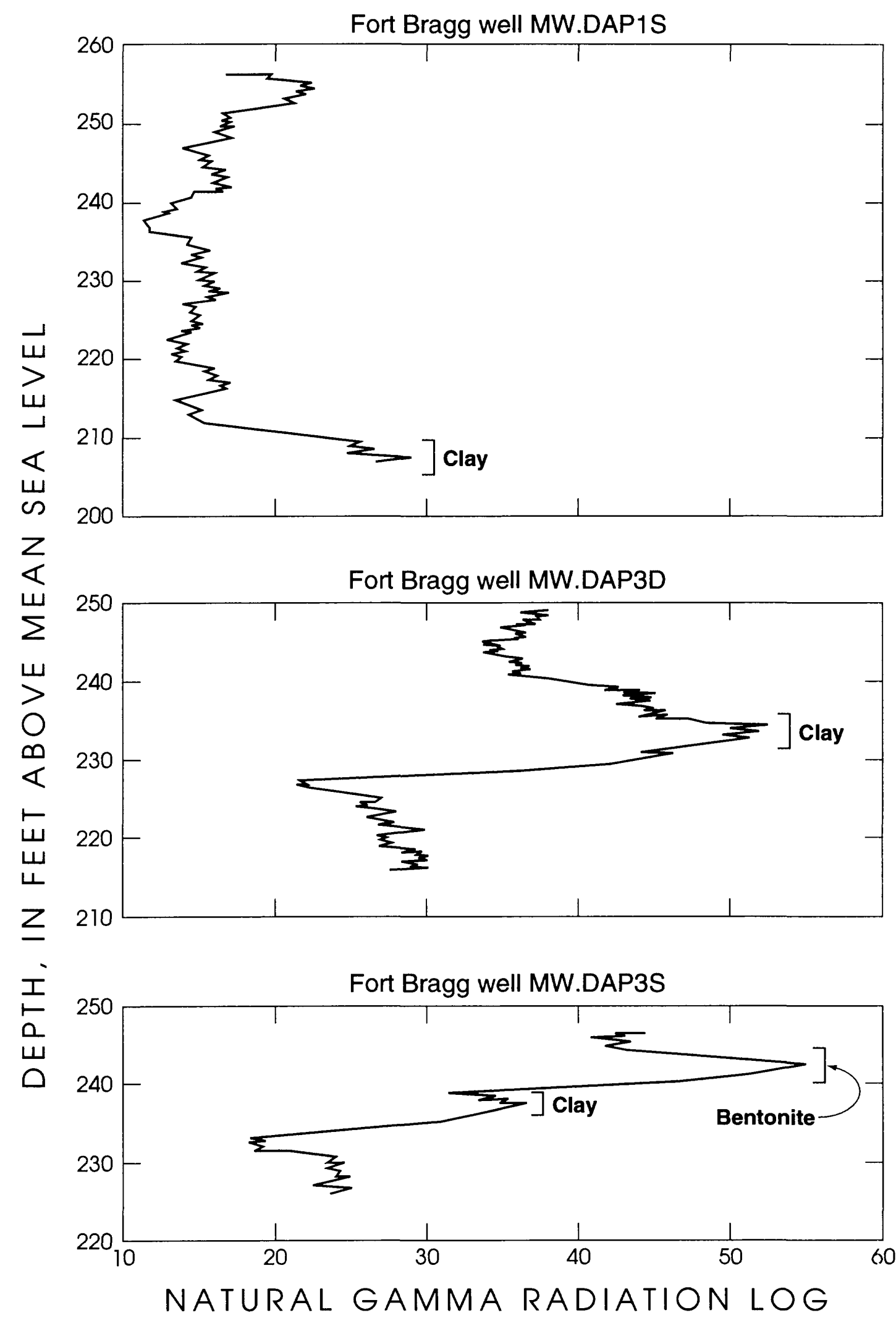

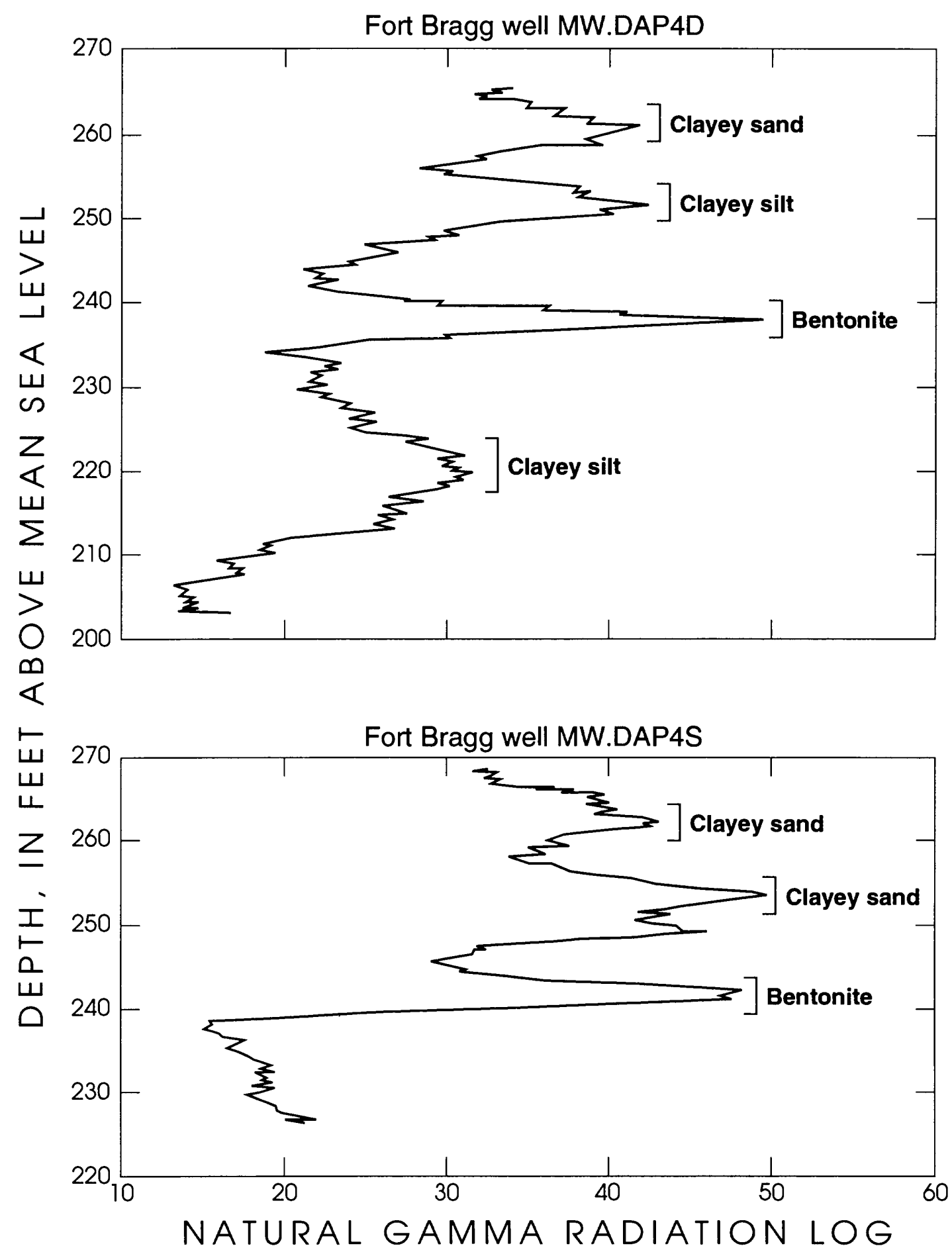


\section{APPENDIX 2}

Descriptive logs of cores from monitoring wells installed during this investigation 

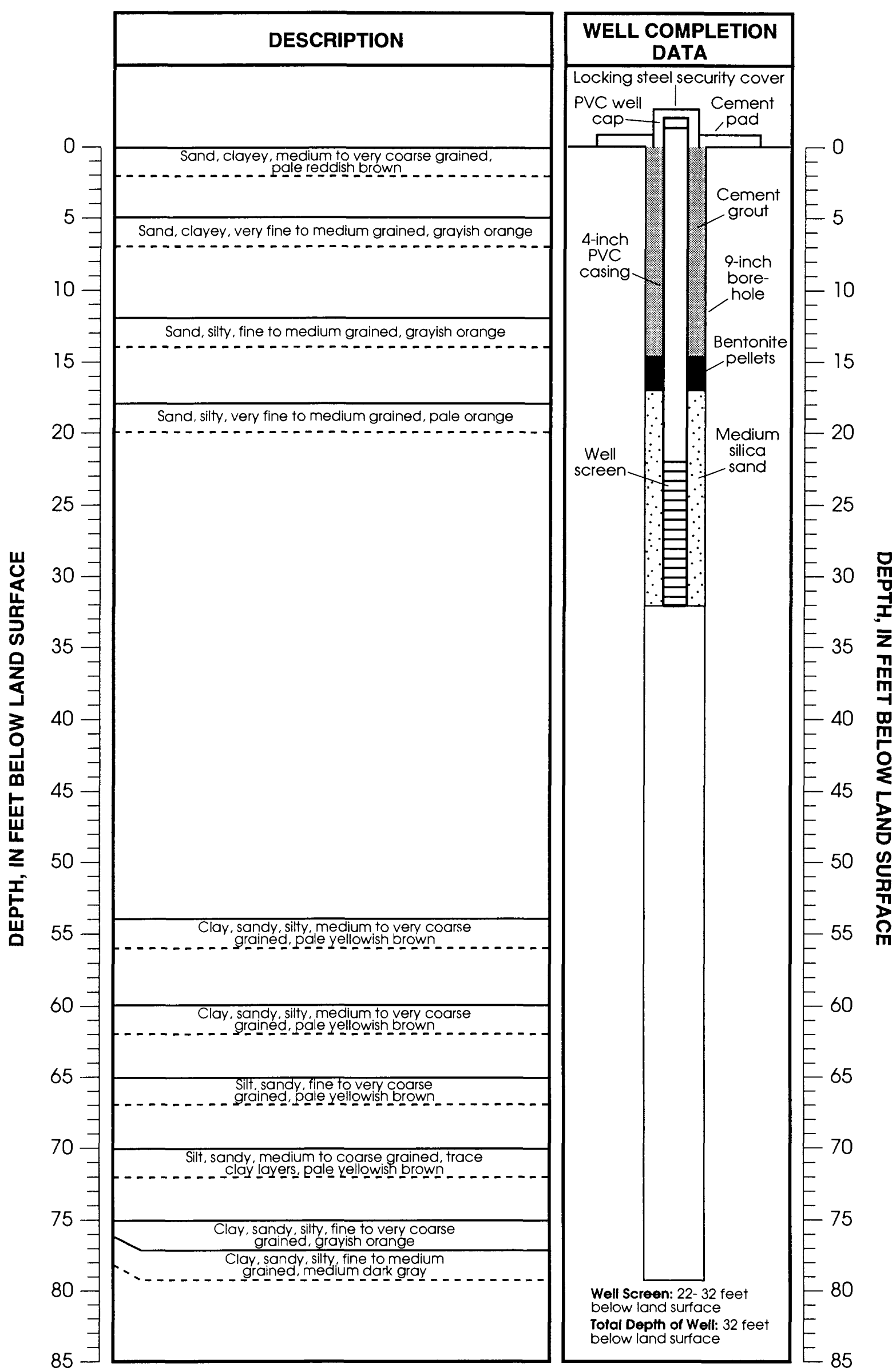

Monitoring well installation record for well MW.DAP1S. 

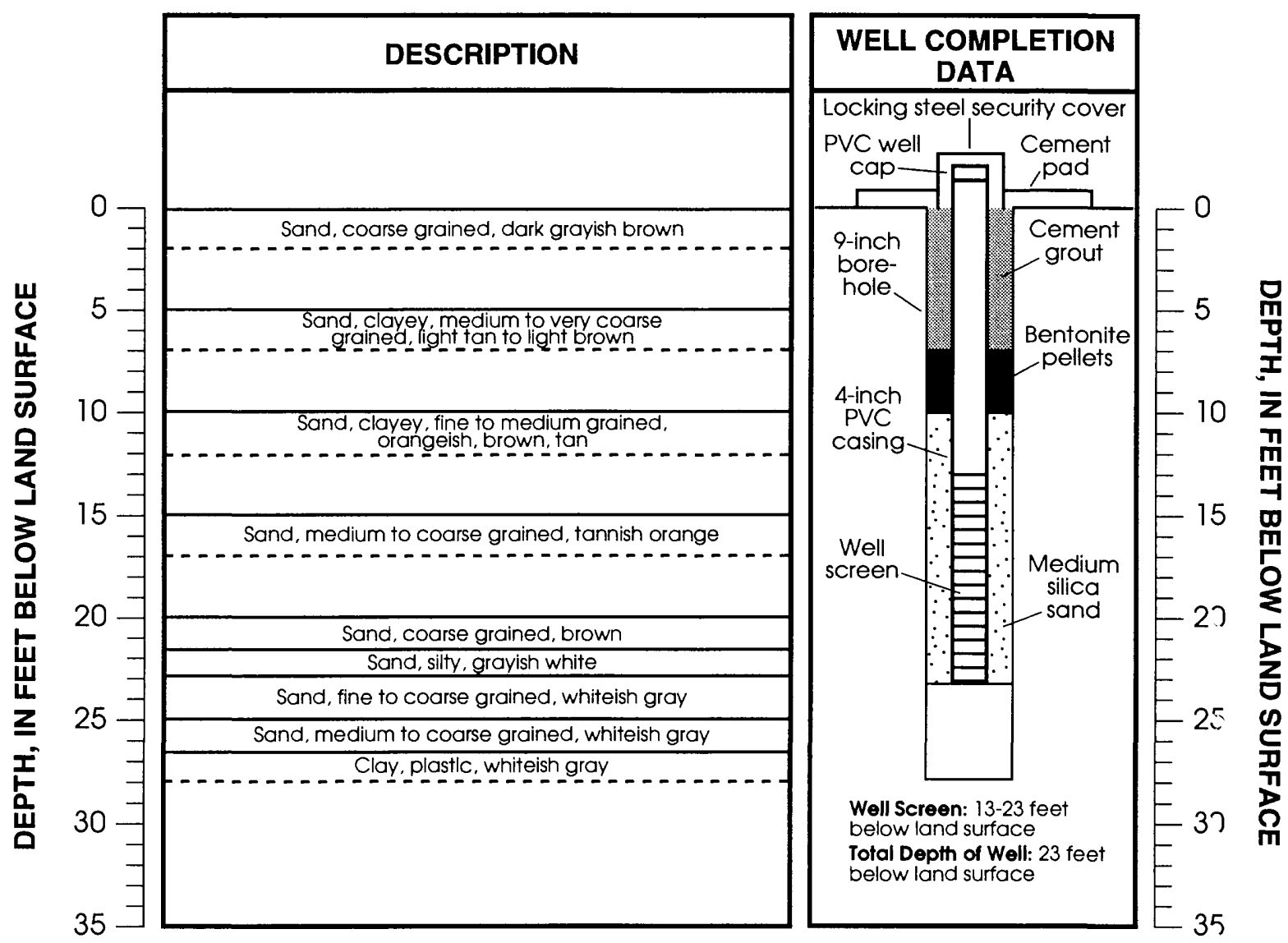

Monitoring well installation record for well MW.DAP2S1. 

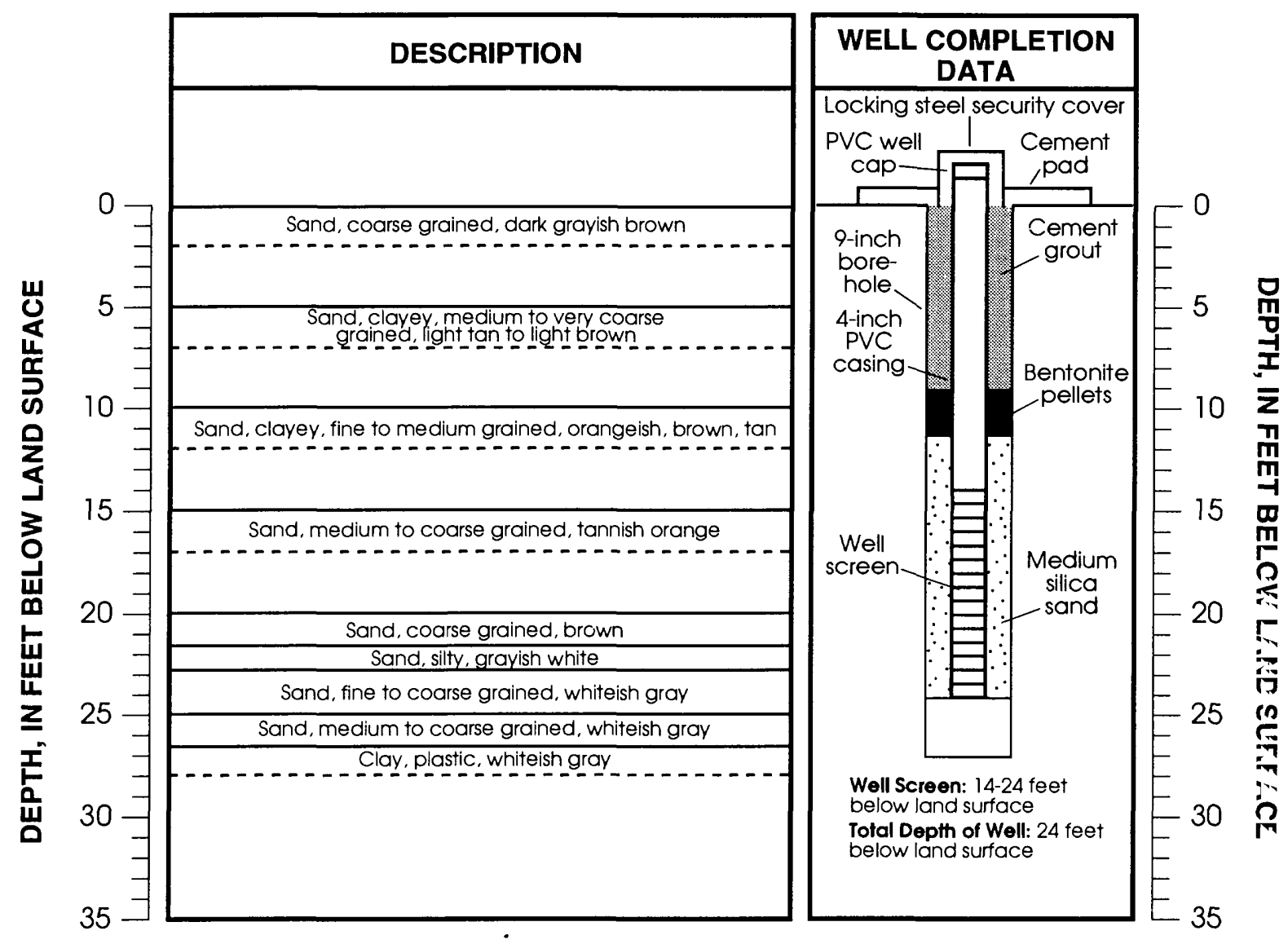

Monitoring well installation record for well MW.DAP2S2. 

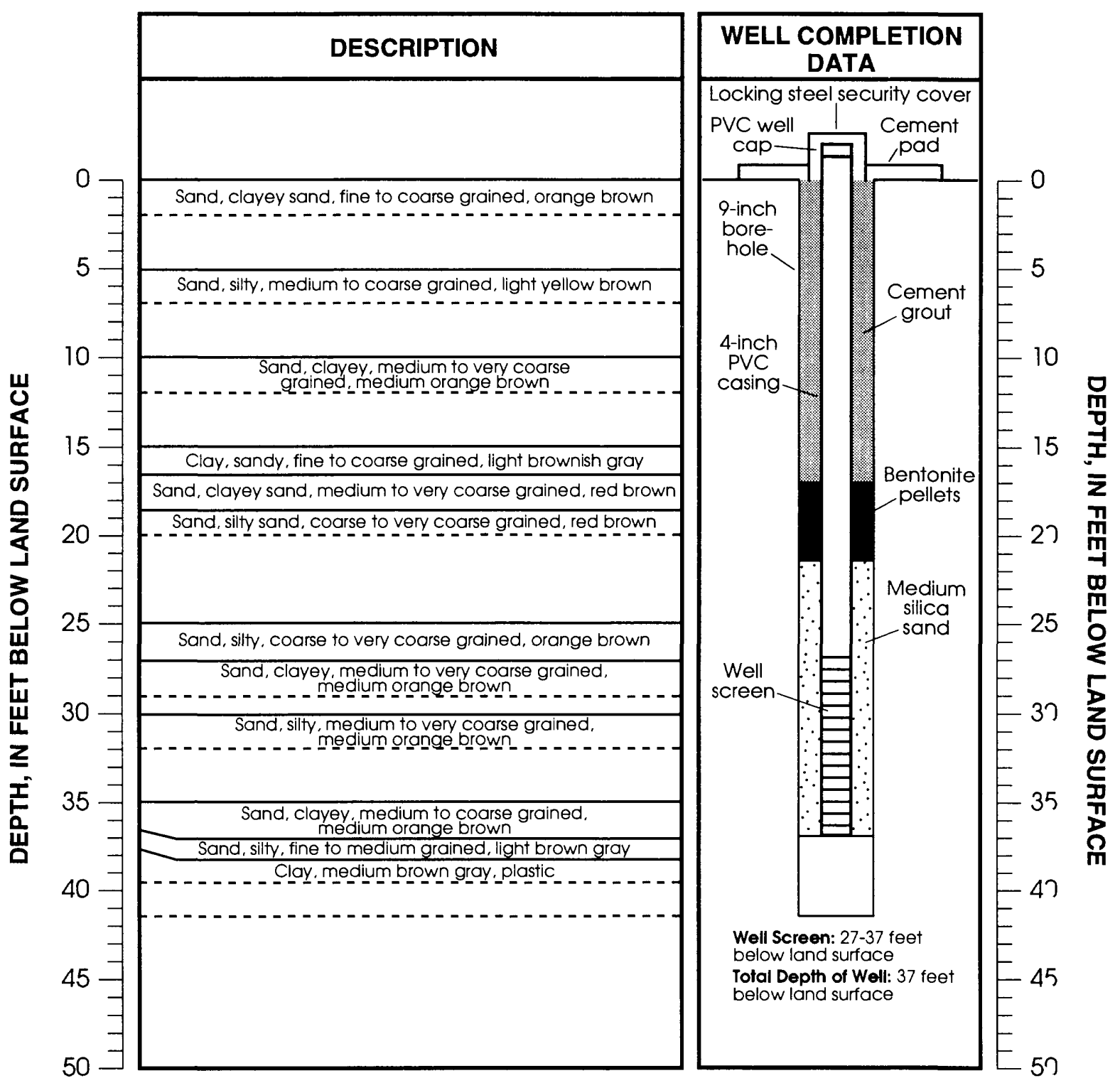

Monitoring well installation record for well MW.DAP3D. 


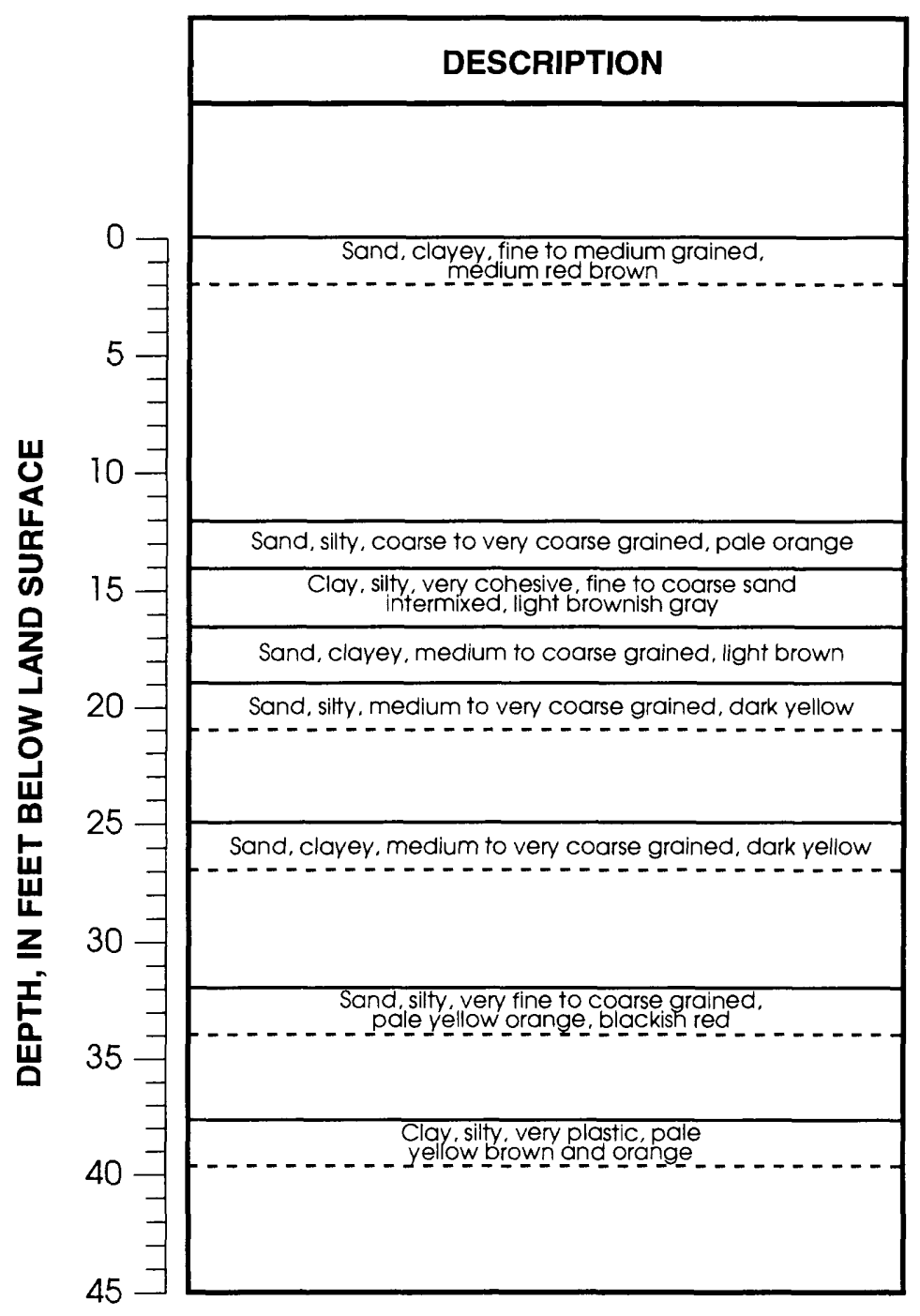

\section{WELL COMPLETION DATA}

Locking steel security cover PVC well I Cement

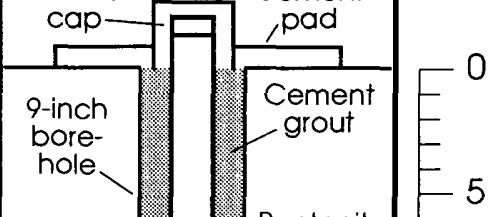
$\left.\begin{array}{lll}\text { A-inch } \\ \text { PVC } \\ \text { casing }\end{array}\right]$ $\begin{gathered}\text { Well } \\ \text { screen }\end{gathered}: \begin{gathered}\text { Medium } \\ \text { silica } \\ \text { sand }\end{gathered}$

Monitoring well installation record for well MW.DAP3S. 


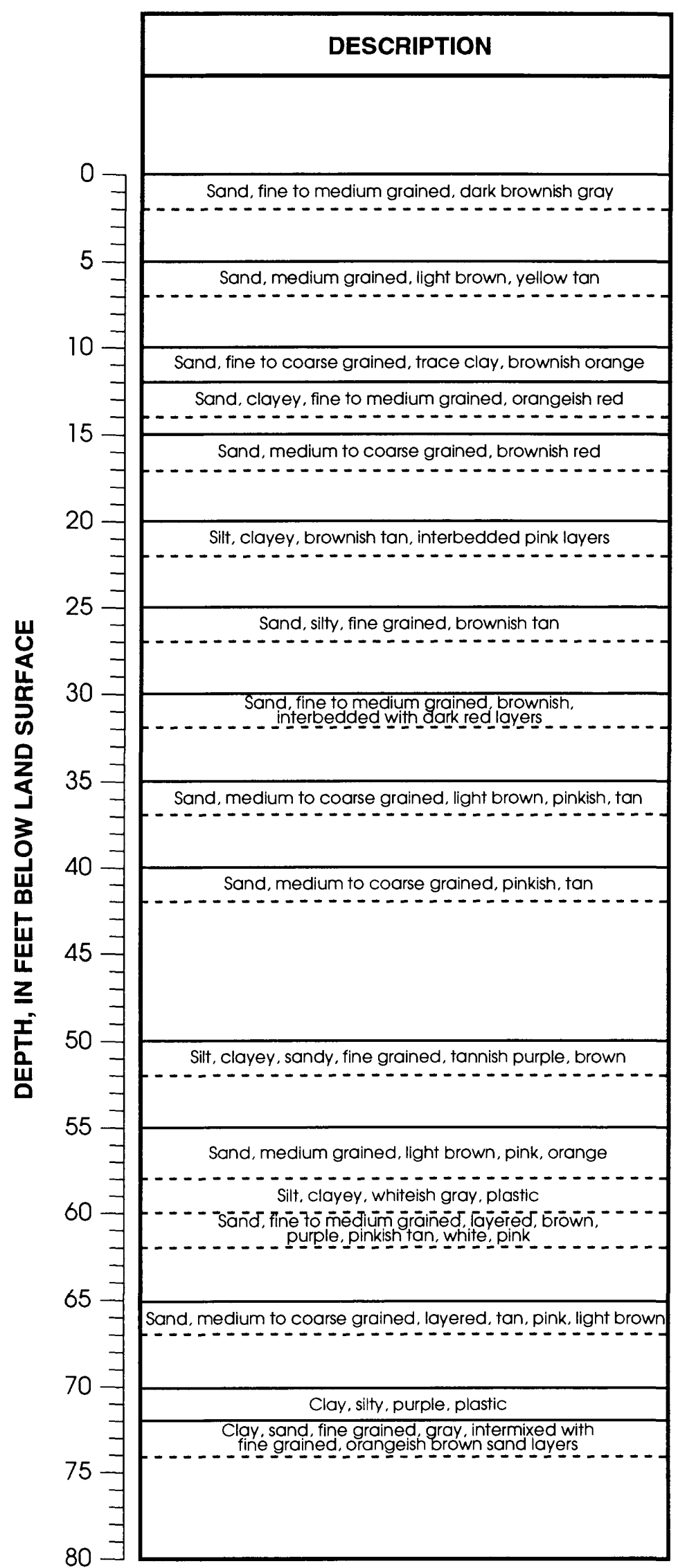

WELL COMPLETION DATA

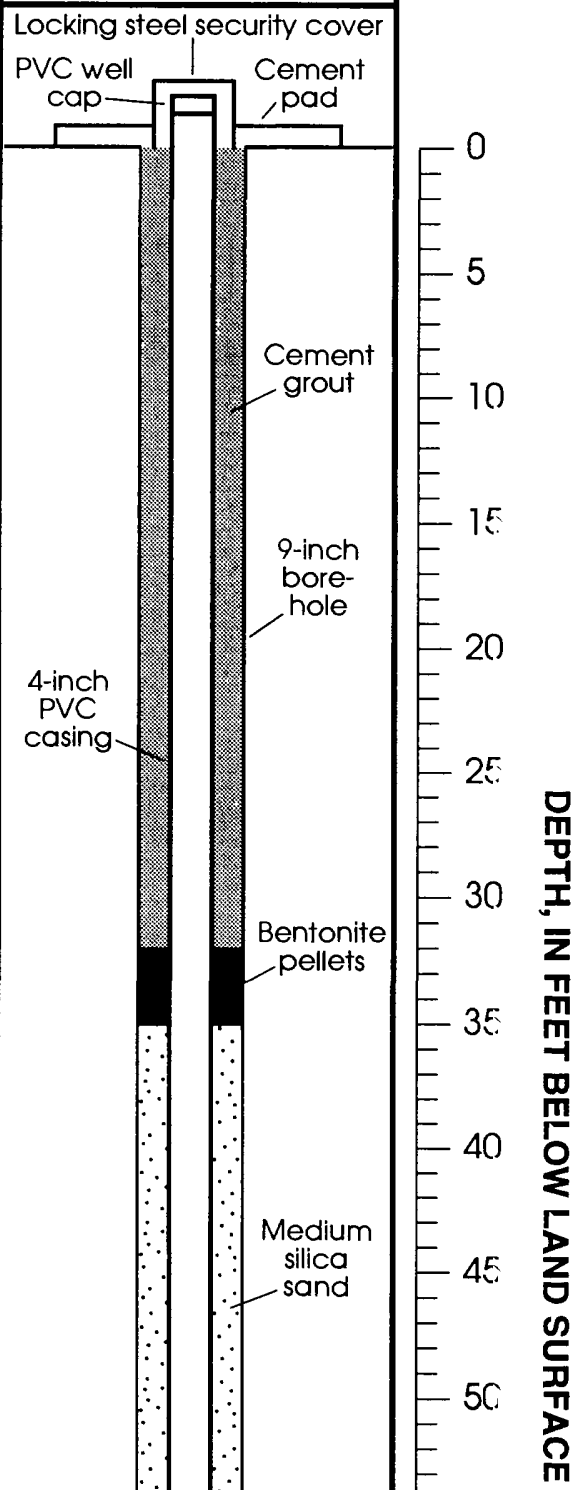

Monitoring well installation record for well MW.DAP4D. 


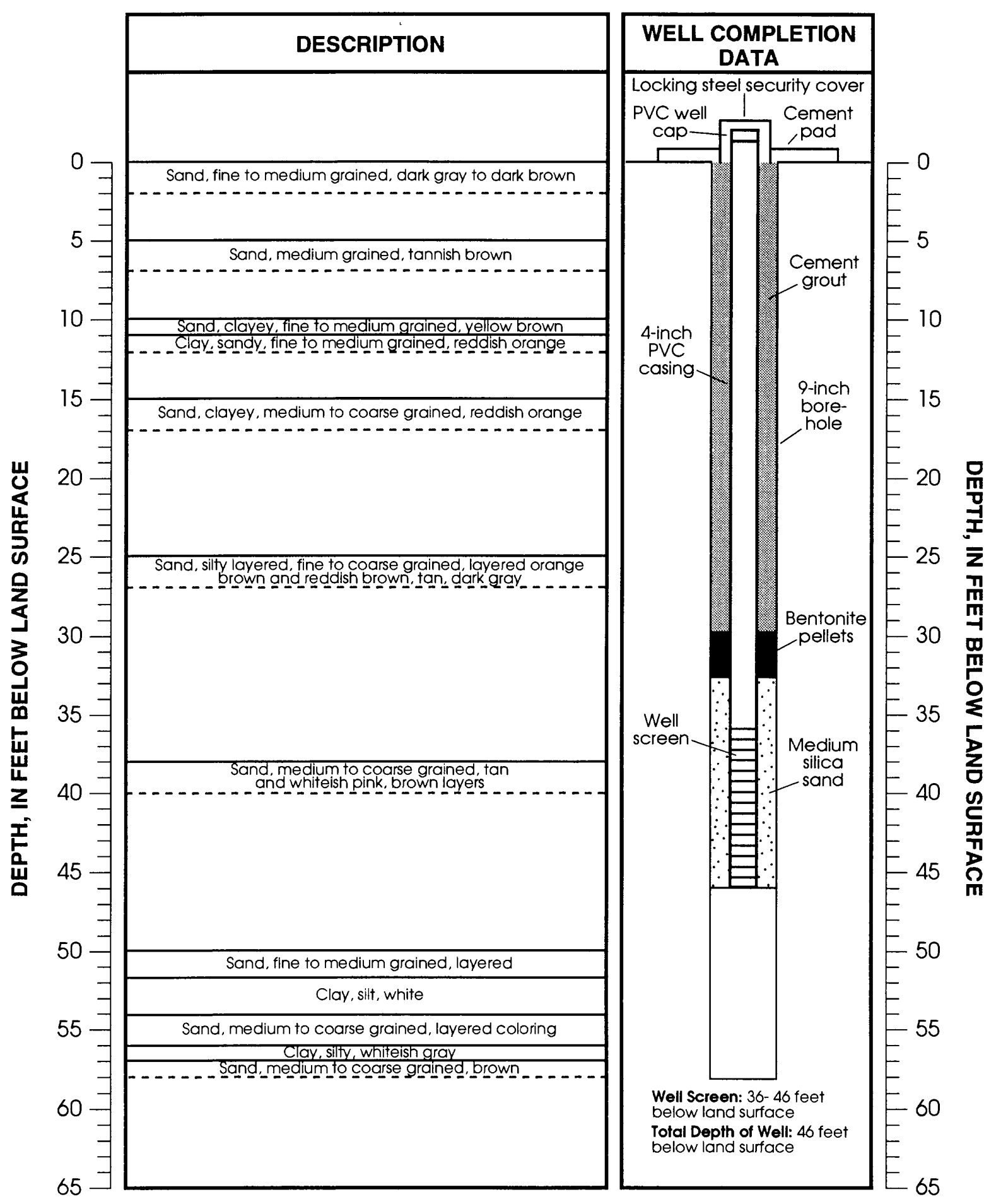

Monitoring well installation record for well MW.DAP4S. 

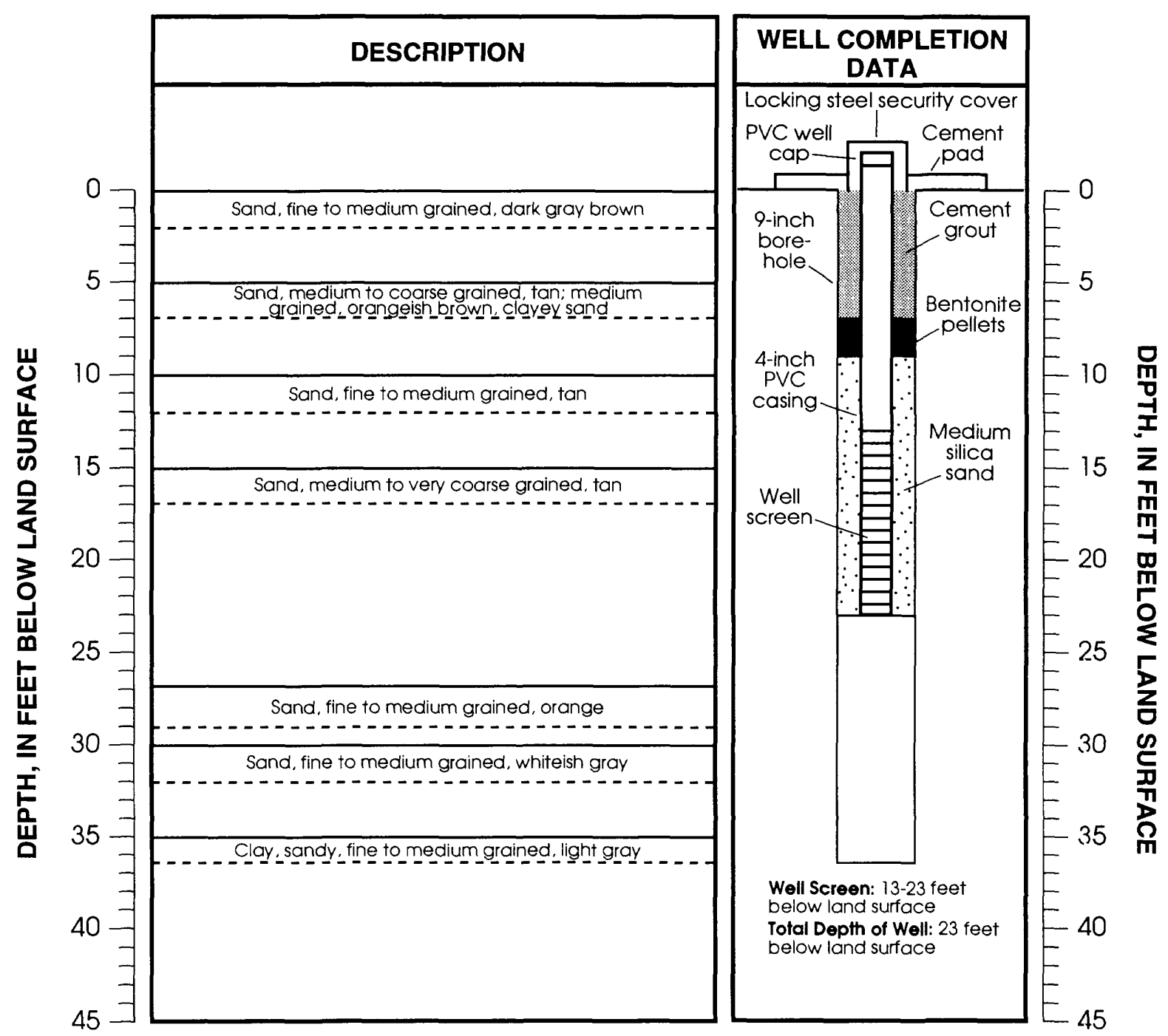

Monitoring well installation record for well MW.DAP5S. 


\section{APPENDIX 3}

Slug-test data collected on wells MW.DAP4D and MW.DAP3D, March 17, 1994 


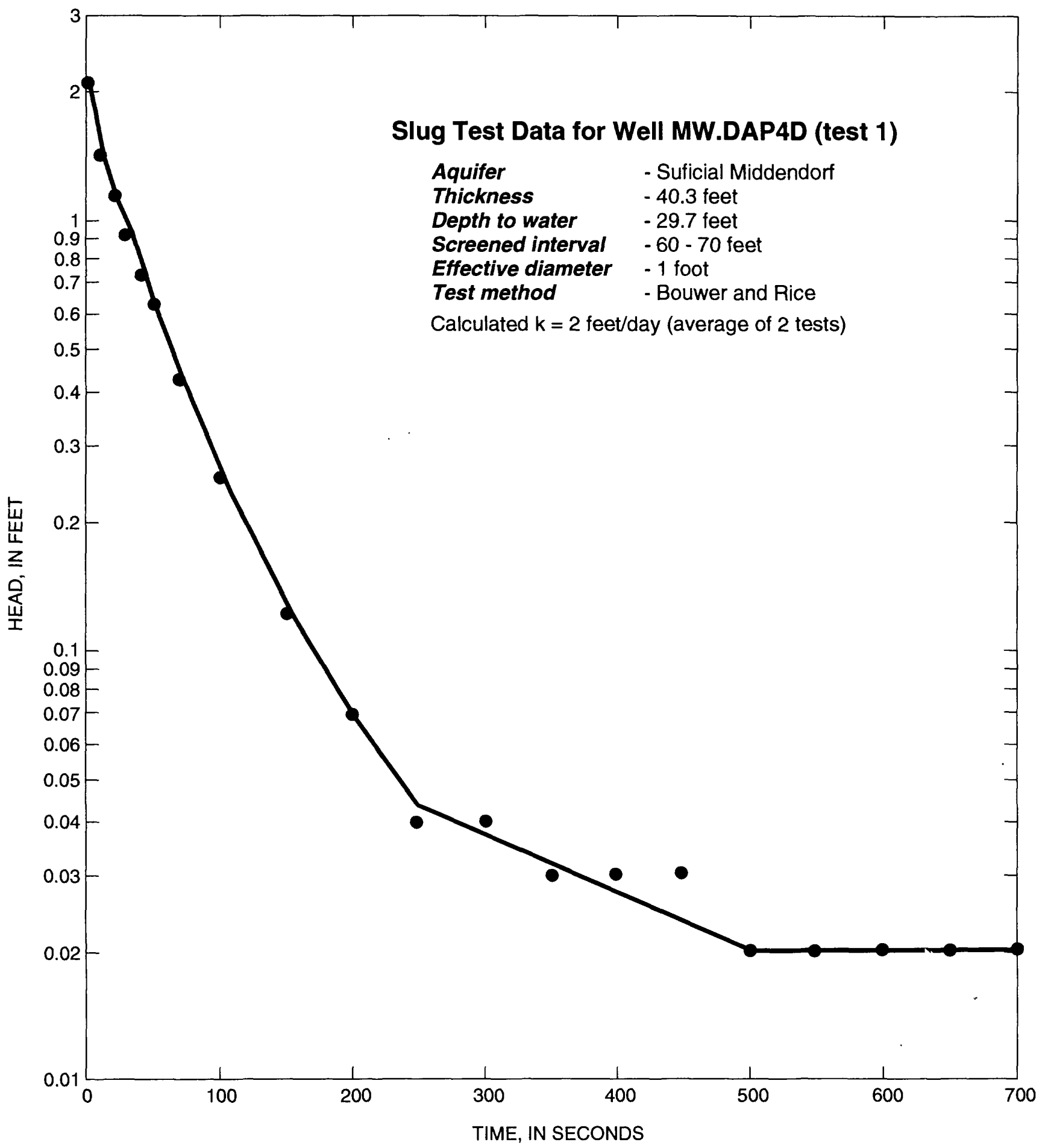




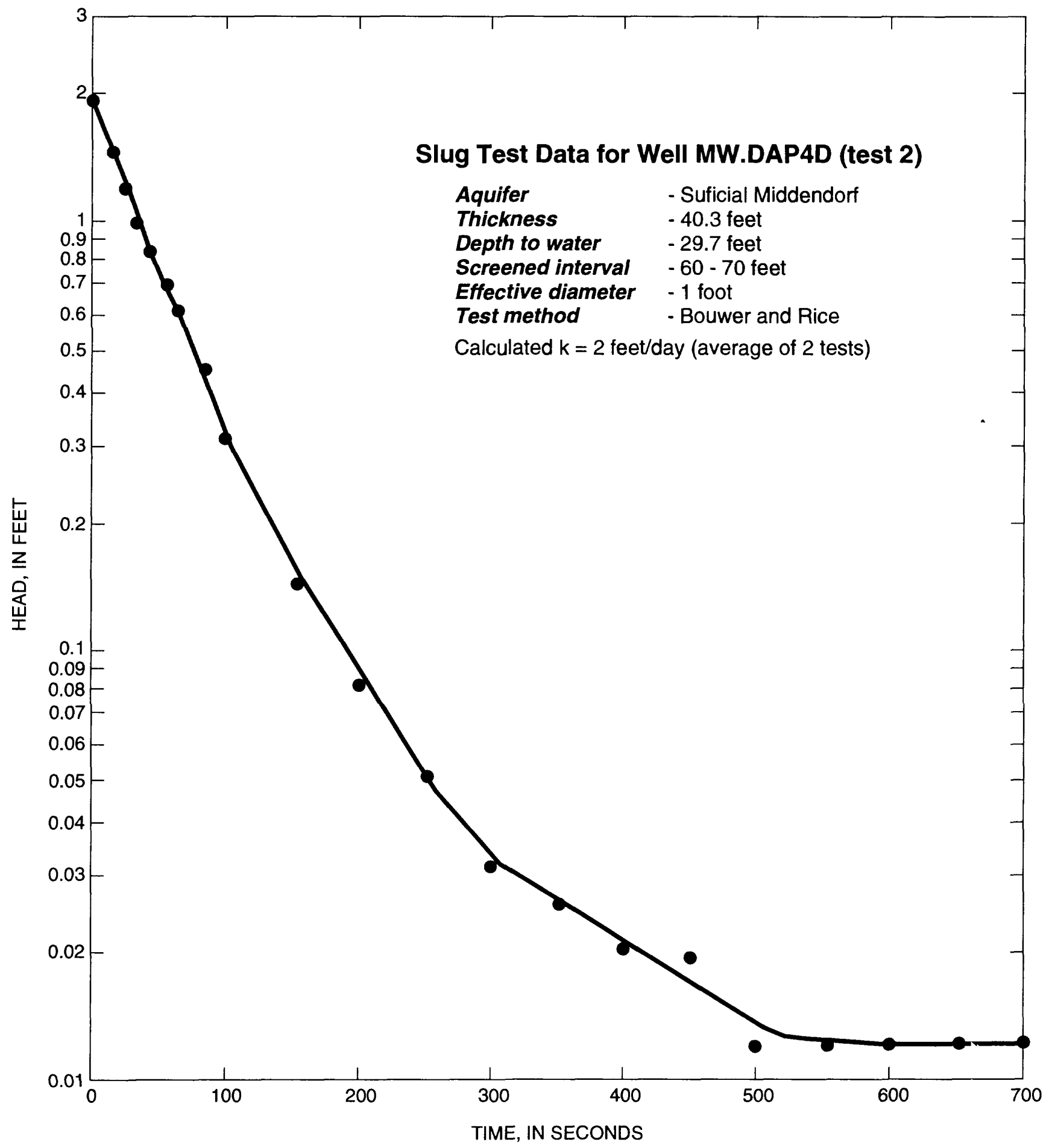




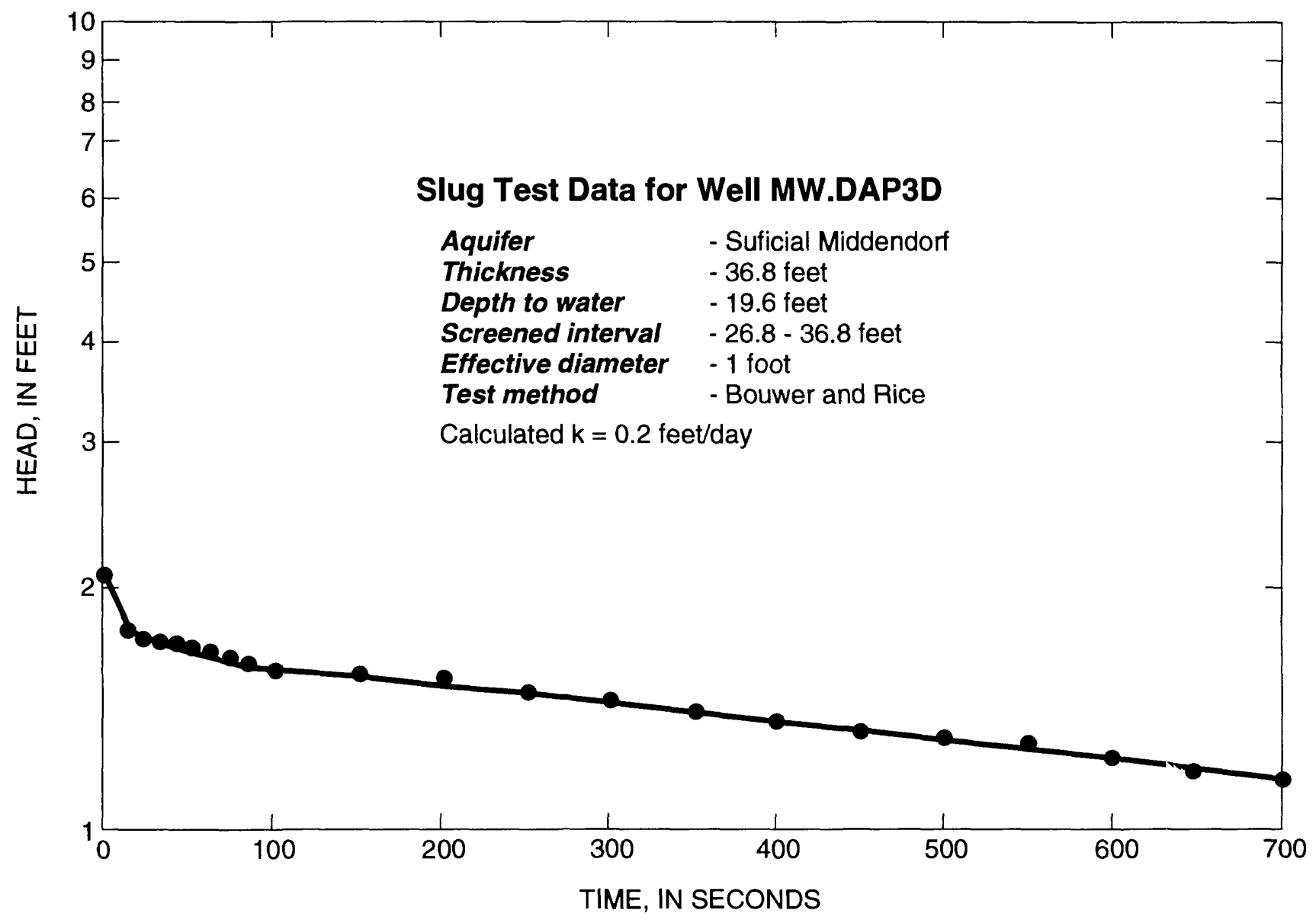

